


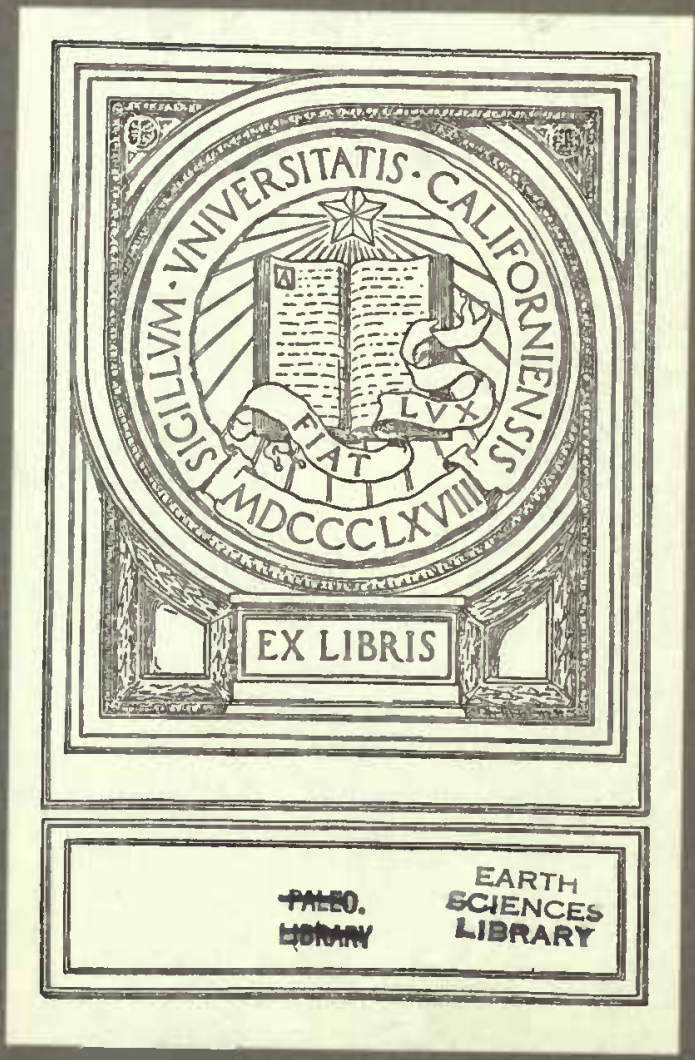


6

-

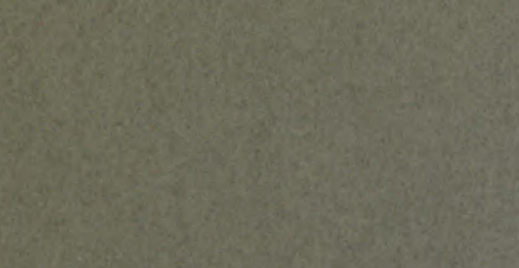

2.

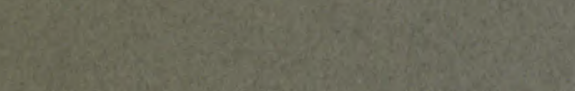

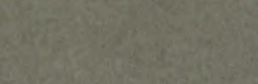

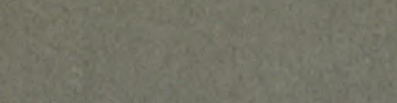

The

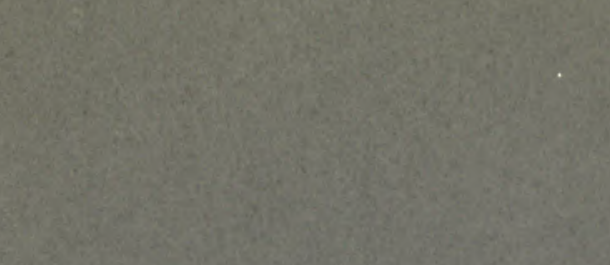

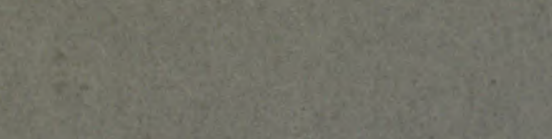

iste

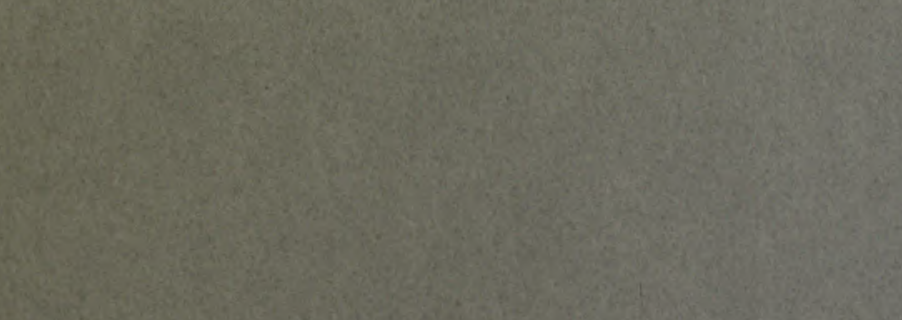
170.

W.

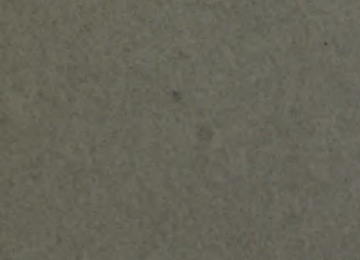

(8)

(2)

1.

3.

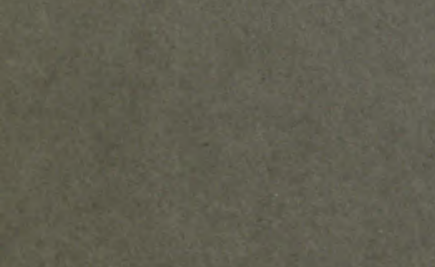

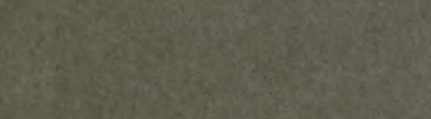

3.

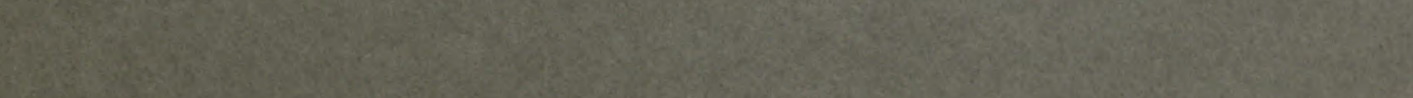
1.5.

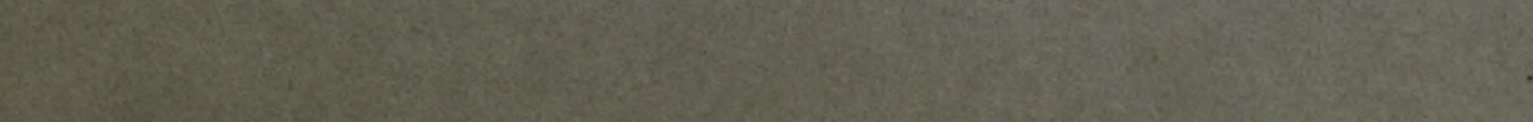

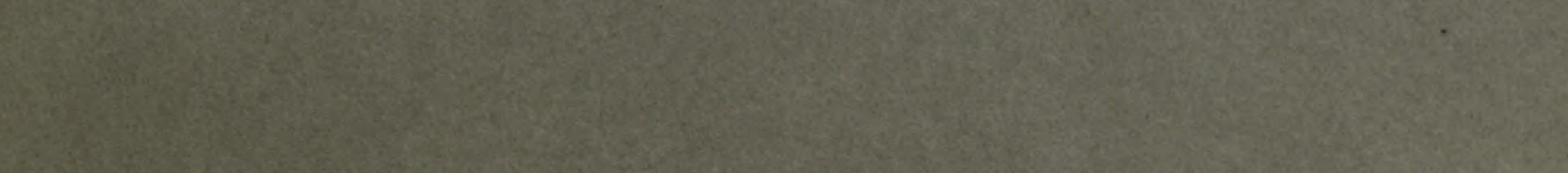
6.

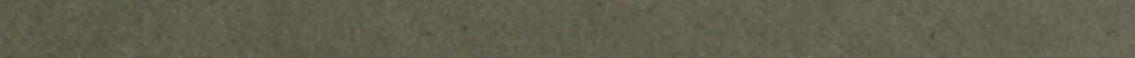





GHOHAOGICAI, SUIRVIIY OH CHINA

V. K. THVG AND W. H. WONG IDIRHCTORIS

\section{Dalscontología Fíníca \\ IGIITOIRE :}

V. IK. TING AND W. H. WONG

Deries $\mathfrak{B}$, Volume 1

Jascicle 1 .

\section{OIRIDOVICIAN HOOSSIILS}

IFIROMIII

NOIRTH CHINA

BBY

AMADIGUS W. GIRAMAU S. ID.

Datæontologist to the Iurvey and Drofesgor of Datrontology in the National University, Deking.

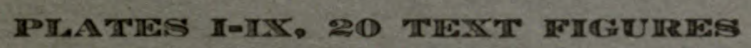

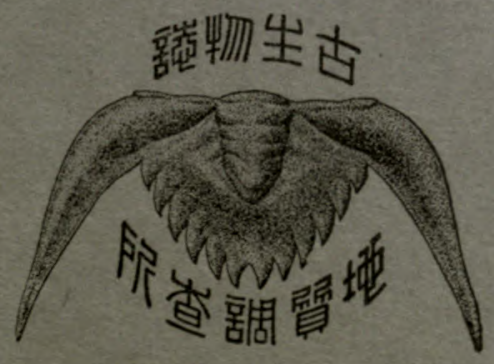

IPHTKING 19R2. 


\title{
Palaeontologia Sinica.
}

中 國 古 生 物 誌

\section{SERIES A. FOSSIL PLANTS OF CHINA.}

VOL. I.

Fascicle I. Zur alttertiären Flora der südlichen Mandschurei, von Rudolph Florin (Riksmuseum, Stockholm, Sweden) 46 pages text,

1 plate, 3 text-figures. (In press).

Other numbers of this series now in preparation will contain descriptions and illustrations of the Palrozoic and Mesozoic Floras of China by Dr. Th. G. Halle and associates in the Palæobotanical Department of the Riksmuseum Stockholm, Sweden, based on extensive collections made by the Geological Survey and associate collectors.

\section{SERIES B. FOSSIL INVERTEBRATES OF CHINA.}

\author{
VOL. I.
}

Fascicie $I$. Ordovician Fossils from North China, by A. W. Grabau.

127 pages text, 9 plates, 20 text-figures. Published April $28,1922$.

Price $\$ 5.00$ Mex.

Fascicle II. Devonian Fossile of Yunnan by A. W. Grabau. (In preparation).

VOL. II.

Palæozoic Corals of China, Part I. The Tetraseptata, by A. W. Grabau.

Fascicle I. Introduction, and descriptions of Petraïdx, Streptelasmaid $x$ and Cyathaxonidx with 1 plate and 74 text-figures. (In press).

Fascicle II. Zaphrentidx and Cyathophyllidix. (In preparation).

\section{SERIES C. FOSSIL VERTEBRATES OF CHINA.}

This series will contain descriptions and illustrations of Tertiary and Quaternary vertebrates of China, by Prof. Carl. Wiinan of Uppsala, Sweden, Prof, M. Boule of Paris, and others, based on large collections made by Dr. Andersson and others for the Survey and. by other organisations and private individuals.

\section{SERIES D. ANCIENT MAN IN CHINA.}

$$
\text { VOI. I. }
$$

Fascicle 1. The Cave-deposit at Sha-Kuo-T'un in Fengtien (in preparation).

Article I. Topographic notes and description of artifacts by J. G. Andersson.

Article 2. Human skeletal remains by Davidson Black. 
PALÆONTOLOGIA SINICA.

Editors:

V. K. Ting and W. H. Wong

\section{Ordovician Fossils}

\section{of}

North China.

BY

AMADEUS W. GRABAU S. D.

Palæontologist to the Survey and Professor of Palæontology in the National University Peking.

With Plates I - IX and 20 Text figures

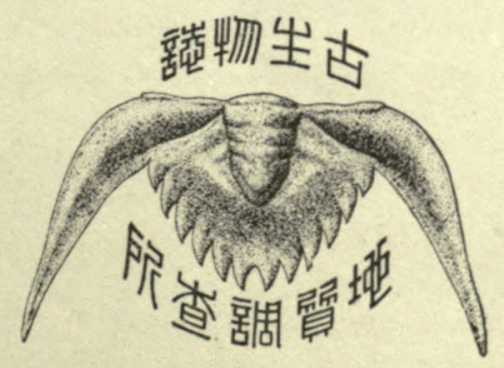

Published by the Geological Survey of China

Peking 1922. 
$\because \because \because \quad \because \vdots \vdots \vdots \vdots \vdots \vdots \vdots \vdots 0$

$\therefore: \square: \because \vdots \vdots: \cdots:$

PUBLISHED APRIL 28, 1922

Printed by

THE COMMERCIAL PRESS.

PEKING.

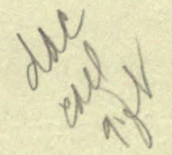




\section{CONTENTS:}

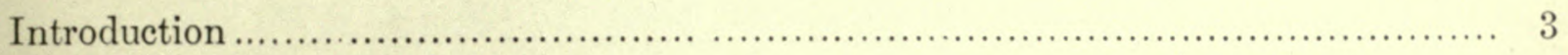

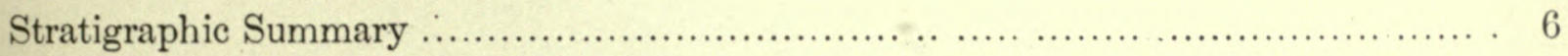

Fauna of the Machiakou or Actinoceras limestone............................ 7

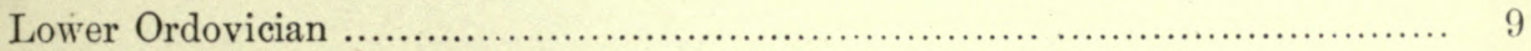

Peilintze Limestone................................................ 10

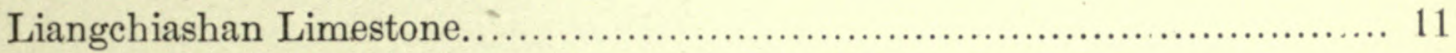

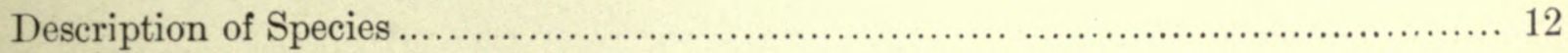

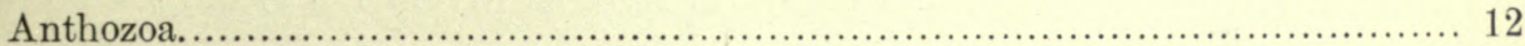

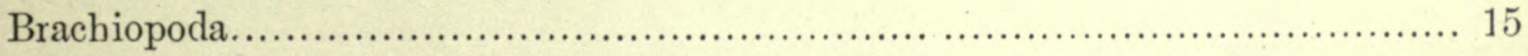

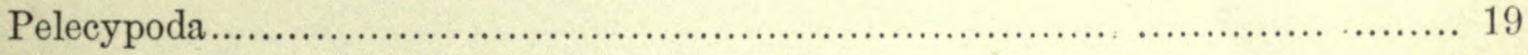

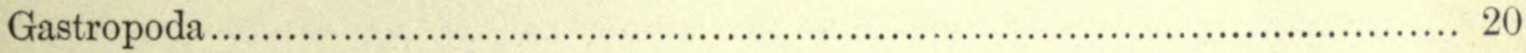

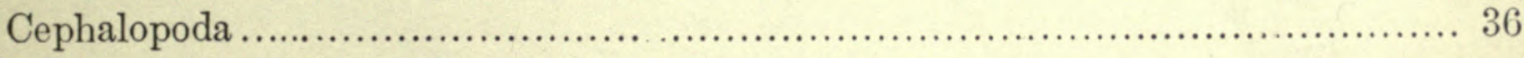

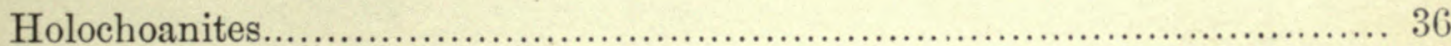

Phylogenetic significance of the siphuncle of the Holochoanites ................ 53

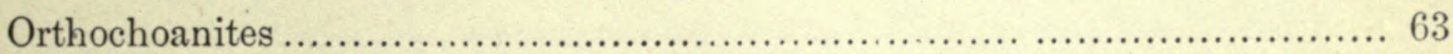

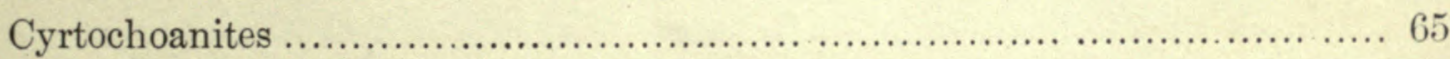

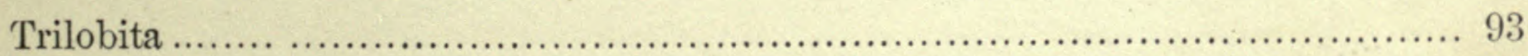

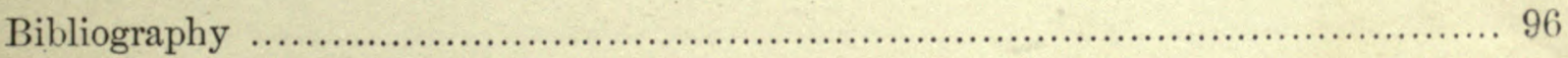

List of Chinese localities referred to in the text, arranged alphabetically under the several provinces.

Explanation of Plates........ 


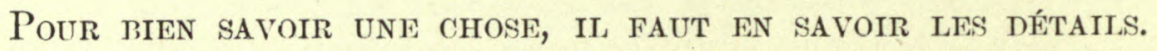

La Rochefoucauld. 


\section{ORDOVICIAN FOSSILS FROM NORTH CHINA.}

A. W. GRABAU,

\section{INTRODUCTION.}

In his classical work on China, Ferdinand von Richthofen classified the great limestone formations which underlie the coal-bearing series of north China as "Kohlenkalk " and referred them to the Carboniferous Limestone of Europe. In this he was not altogether wrong, for we now recognize the existence of Lower Carboniferous (Dinantian) limestones in north China, which carry many elements of the Carboniferous Limestone fauna of western Europe.

The greater part of the limestone series here under consideration was expressly excluded by v. Richthofen from his Sinian System which comprised the Cambrian and older rocks. It and a part of the rocks included in the Sinian are now known to be of Ordovician age, as was indeed recognized by Frech, who in the fifth volume of $\mathrm{v}$. Richthofen's monumental work, published in 1911, described two specimens of Actinoceras, (A. richthofeni Frech) collected by von Richthofen in Manchuria, and correctly referred them to the Upper Ordovician. Frech further recognized that this form was similar to, or even identical with, a species of Actinoceras from Canada which was figured by Barrande under the name Actinoceras richardsoni Stokes. Frech also described a fragmentary gastropod collected by von Richthofen in the same strata, and referred it tentatively to Raphistoma æquilaterum Koken which occurs in the Chasmops-Kalk (Upper Ordovician) of western Europe. He also notes the occurrence of specimens of Actinoceras sp. and Trochoceras sp, from Shantung, in the British Museum, together with Dalmanella ef. testudinaria (p. 8).

Previous to the appearance of Frech's monograph, G. C. Crick (1903) had described and figured several specimens of Actinoceras obtained by the Rev. Samuel 
Couling from the neighborhood of Tsingchou-Fu, Kiaochow, Shantung. Crick however did not identify his specimens specifically, referring to one as closely allied to Actinoceras (Ormoceras) tenuifilum Hall from the Black River formation of New York, and to another as possibly representing the genus Gonioceras, a reference which now appears to be probably correct. Besides the cephalopods, Crick mentioned the occurrence of several small brachiopods. According to Buckman " the general appearance suggests Oithis (Dalmanella) testudinaria Dalman, an Ordovician species"*). This is the first published demonstration of the Ordovician age of these limestone in north China. In 1906 Th. Lorenz ** described the following species from the Ordovician of Shantung the first three from Ho-shan the fourth from Santefan.

1. Asaphus bochmi Lorenz.

3. Hyolithes sp.

2. Maclurea logani Salter.

4. Plectambonites sericeus (Sowerby).

Frech (in Richthofen $V$ p. 14) referred the first three of these to the Iiddle Ordovician the fourth to the Upper Ordovician.

In their investigations of the geology of parts of northern China which appeared before Frech's monograph, Bailey Willis and Elliott Blackwelder (in 1903-1904) recognized that the greater part of von Richthofen's Kohlenkalk was to be referred to the Ordovician. Professor Stuart Weller, of the University of Chicago, who studied the fossils collected by Blackwelder, recognized the existence of the cephalopod genus Orthoceras, the gastropods Machirea? or Helicotoma? and Lophospira, the trilobite Asaphus?, and the brachiopods Strophomena and Orthis (Dalmanella?) in the Ordovician rocks of Shantung but he was unable to make specific determinations because of the poor state of preservation of the fossils. He however described a number of species collected by Blackwelder in the Yangtze region (south China) *** and recognized their affinities with European Middle Ordovician species. Previously, several authors had deseribed Ordovician fossils from south China among them S. P. Woodward (1856) Kingsmill (1869) and Grieve (1887). The first described the well-known "Pagoda stone" as Orthoceras sp. and this was later redeseribed by Foord as Oithoceras chinense Foord (1888). Kayser and Frech also described a number of Ordovician species from southern China, (v. Richthofen Vols. IV and V) and a number of these have since been redescribed with others by H. Yabe and I. Hayasaka in their work "Palæontology of South China" (1920). Several Ordovician species from south China were also described and recorded

*) Criek loc. cit p. 483 .

**) Beitrlige zur Geologie und Palæontologie von Ostasien, pt II pp 84-90 pl VI.

China.

***) For stratigraphic studies the Yangtzekiang forms the approximate dividing line between North and South 
by Martelli (1901) Mansuy (1902) Brown (1913) and G. Pellizzari (1913).

In all these studies however, only one new species was recognized in addition to the Actinoceras from the Ordovician of north China, namely Asaphus bochmi Lorenz from Shantung, though a number of generic determinations were made and a few forms identified with European species. Actinoceras richthofeni has remained up to the present the only specifically identified cephalopod known from the Ordovician of north China, lut this species was definitely known only from Manchuria.

During the progress of investigations carried on by the Geological Survey of China, a considerable number of specimens of Actinoceras was obtained from the provinces of Chilhli and Shantung. Naterial was also sent to the Survey by residents in various distriets. Only a few other fossils were however obtained. Early in the present year some additional species were obtained from T'angshan in the Kaiping coal basin by Messr's. Fred. K. Morris, Geo. B. Barbour and A. C. Terrill, and later; a survey expedition, in charge of the author, began a systematic study of the stratigraphy of certin parts of the Kaiping basin. The party included Professor George B. Barbour of Yenching college (Peking Christian University) and Messrs. Y. C. Sun and S. C. Chean of the Survey. In the field we were joined by Dr. F. F. Matthieu, Geologist of the Kailan Mining Administration and Mr. Jacques Gerard engineer and geologist of the Chaokouchunng mines and later ly Mr. C. H. Huang of the Machiakou mining staff *). The greater part of the fossils from the upper beds herein described was collected at that time.

The discovery of the Lower Ordovician fauna of the Ching-wang-tao region north of the Kaiping basin is to the credit of Dr. F. F. Matthicu who placed the material in my hands for description, and with true scientific spirit has deposited the types and illustrated specimens in the museum of the Survey, where they are accessible to all students and specialists.

The Ordovician species at present known from north China comprise 31 genera

*). It gives ne great pleasure to acknowledge the uuiform courtesy and belpfulness of the offieers of tho rarious inines notably M. Alexandre Doquier Chief of Staff Tangshan, M. Maurice Derwiduee Chief engineer of the Chaokoucbuang mines and Mr. Ch. P. Huang, Chief engineer of the Machinkou mincs. To Messrs. Matthieu, Gerard and C. H. Iluang we are also greally indebted for cffieient aid and guidance in our field-work, and to the first for placing at my disposal collections preriously and since then nade by him, especially in Slaantung, and from the Jower Ordovieian beds of the Chingwangtao region of east Chihli, this lower fauna having been discorered by hin. To Mr. W. S. Nathan president of the Kailan Mining Administration special acknowledgments and thanks are gladly tendered for his conrtesy in giring us unlimited opportunily to study the mines and properties in the Traiping basin under his control, and for putting at our disposal housing aecomodations, transportation and mechanical assistance. 
and 58 species 45 of these being specifically identified.* All except five of the species are new. Three new genera, and a new family of cephalopods, that of the Chillioceratidx are described.

\section{STRATIGRAPHIC SUMIARY.}

Willis and Blackwelder applied the name Tsinan formation to the entire Ordovician series of North China, which they regarded as a unit. The name was taken from Tsi-nan-fu in Shantung near which the upper beds of the series are well exposed. It is now known that there are several Ordovician formations in north China, with probably a disconformity between the higher and the lower divisions. The base of the Ordovician has been definitely located in the vicinity of the little hamlet of Yehli, about 9 li or about 3.6 miles east-north-east of Machiakou in the Kaiping Coal Basin. Here the Ordovician beds rest disconformably upon the Upper Cambrian or Cambro-Ordovician transition beds, the Fengshan formation, which carries a fauna recalling the Ceratopyge fauna of Europe, including a new species of Ceratopyge. The disconformity is marked by an irregular erosion surface of the Fêngshan formation followed by a basal conglomerate which marks the beginning of the Ordovician limestones **).

To the limestone immediately succeeding this basal conglomerate we have given the name Yehli formation, and from it the following species have been oltained.

\section{CEPHALOPODA}

\section{Suecoceras yehliense Grabau}

Suecoceras attenuatum Grabau

Extremely meager as this fauna is, it is sufficient to indicate early Ordovician, but whether it is Lower or early Middle Ordovician must for the present remain undetermined. The limestones of this region lave a total thickness, according to the measurements of Mr. H. C. T'an; of approximately 800 meters, but whether this series is continuous or separated into two divisions by a hiatus, has not yet been ascertained:

\section{UPPER ORDOVICIAN}

The upper beds of the Ordovician of the Kaiping basin are well exposed at Machiakou, south-west of Yehli, and from this locality the formation is named the Machiakou division or Machiakou formation. This is the typical Actinoceras limestone, widely exposed in the Kaiping basin from Chaokouchuang on the east to Tangshan on the west. It is again known by fossils from the Western Hills of Peking, from the Shansi border,

*) This includes two varicties. Tro others bave been tentatively referred to known species.

**) This will be described by the author in the Bnlletin of the Geological Survey. 
from south Chihli, from various parts of Shantung and from Manchuria. The fossils so far obtained from it occur in the upper 10 to 15 meters, but it must be clearly understood that over this entire region of its known-exposure it has suffered pre-Carboniferous erosion, and that beds of late Palæozoic age - usually Lower Carboniferous or Dinantian, but sometimes Upper Carboniferous or Uralian and in some cases perhaps Permo-Carboniferous beds rest upon them. Thus the fossiliferous upper beds are probably not always of the same horizon, though it is possible that Actinoceras may have only a limited vertical range, in which case the pre-Carboniferous erosion over wide areas was relatively uniform in amount.

\section{FAUNA OF THE MACHIAKOU OR ACTINOCERAS LIMESTONE}

The following species have been obtained from the upper part of the Machiakou or Actinoceras limestone *).

BRACHIOPODA

1 Orthis calligramma Dalm. var. orthambonites (de Vern.), Chihli

* 2 Ortlis? sp., Shantung (Weller)

* 3 Dalmanella ef. testudinaria Dalm., Shantung (Crick, Frech)

4 Strophomena cf. incurvata (Shepard), Chihli

* 5 Strophomena sp., Shantung (Weller)

* 6 Plectambonites sericeus (Sow.), Shantung (Lorenz)

\section{PELECYPODA}

\section{Ctenodonta symmetrica Grabau, Chih»li}

\section{GASTROPODA}

* 8 Maclurea? or Helicotoma? sp., Shantung (Weller)

* 9 Maclurea logani Salter, Shantung (Lorenz)

10 Eccylioptenus kushanensis Grabau, Chihli

11 Eccyliomphalus tangshanensis Grabau, Chihli

12 Lophospira morrisi Grabau, Chihli .

13 Lophospira pulchelliformis Grabau, Chihli

14 Lophospira trochiformis Grabau, Chihli

15 Lophospira acuta Grabau, Chihli

16 Lophospira gerardi Grabau, Chihli

17 Lophospira gerardi var. laxa Grabau, Chihli

*). Tha species proceded by and asterisk are recorded by Criek, Weller, Iorenz, Frech ete. from Shantung and one No. 34, from Manchuria. All of these, except the last, I have not seen. 
18 Lophospira tcrrassa Graban, Chihli

19 Lophonspira obscura Grabau, Chihli

* 20 Lophospira sp., Shantung (Weller)

21 Pagodispira derwiduii Grabau, Chihli

22 Pagodispira dorothea Grabau, Chihli

23 Pagodispira dorothea var. laxa Grabau, Chihli

24 Liospira barbouri Grabau, Chihli

* 25 Liospira sp. (Raphistoma ef. xquilaterum Koken, Frech), Manchuria (Frech)

26 Salpingostoma terrilli Grabau, Chibli

CONULARIDA

* 27 Hyolithes sp., Shantung (Lorenz)

CEPHALOPODA

28 Vaginoccras tsinancnse Grabau, Chihli

* 29 Orthoceras sp. (several), Shantung (Weller)

30 Cycloceras? peitoutzense Grabau, Chilıli

31 Stereoplasmoceras pseudoseptatum Grabau, Chihli, Shantung

32. Stereoplasmoceras machiakounense Grabau, Chihli, Shantung

33 Stereoplasmoceras actinoceriforme Grabau, Chihli

34 Actinoceras richthofeni Frech, Chihli, Shantung, Manchuria (Frech)

35 Actinaceras tani Grabau, Chihli, Shantung

36 Actinoceras coulingi Grabau, Shantung (Crick), Honan, Chihli

37 Actinoceras suanpanoides Grabau, Shantung

38 Actinoceras submarginale Grabau, Chihli

39 Actinoceras nanum Grabau, Chihli

40 Actinoceras curvatum Grabau, Shantung

41 Cyrtactinoceras frechi Grabau, Chihli, Shantung

42 Gonioceras shantungense Grabau, Shantung

* 43 Trochoceras sp., Shantung (Frech)

\section{TRILOBIT E}

44 Asaphus bxhmi Lorenz, Shantung (Lorenz), Chihli

45 Asaphus? sp. or Tsotelus sp., Chihli

* 46 Asaphus? sp., Shantung (Weller)

A consideration of this fauna clearly shows it to he of early Upper Ordovician age corresponding to the fauna of the Black River limestone of New York and Canada and to 
the early Trenton beds of the central and eastern United States and Canada. Although no species can be said to be absolutely identical, (except perhaps Actinoceras richthofeni, with which is identified a specimen figured by Barrande from Canada*) still the majority are representatives of species oceurring in the American early Upper Ordovician formations, and indeed, in some cases these Chinese species are hardly more than geographical varieties of the American forms. As such they indicate a very close correspondence of horizons. The presence in our Chinese fauna, of forms closely analogous to species found in the Stones River or upper Middle Ordovician of North America, indicates that the horizon is to be regarded as at the boundary-line between Middle and Upper Ordovician. Thus it is quite safo to correlate the Actinoceras horizon essentially with the Black River formation of North America. How much of the underlying series of limestones represents Middle Ordovician and what part is of Early Ordovician age, cannot at present be determined.

The only European form I have noted in addition to those recorded by Criek, Lorenz and Frech, is Orthis calligramma variety orthambonites, of the type figured by de Verneuil from Russia.

\section{LOWER ORDOI'ICIAN.}

Undoulted Lower Ordovician fossils were discovered ly Dr. F. F. Matthieu in the Shi-mun-chai region northwest of Ching-wang-tao in northeastern Chibli. The stratigraphic succession here is as follows according to Dr. Matthieu. $\left.{ }^{* *}\right)$

CARBONIFEROUS FORNATION

(Great hiatus and disconformity) ORDOVICIAN FORMATION

$\begin{array}{lllllllllllll}\text { Liangchiashan formation } & \ldots & \ldots & \ldots & \ldots & \ldots & \ldots & \ldots & \ldots & \ldots & \ldots & \ldots & 275 \\ \mathrm{~m} .\end{array}$

Gray massive more or less dolomitic limestone witls fossiliferous horizon

(F3) $53 \mathrm{~m}$. below the top.

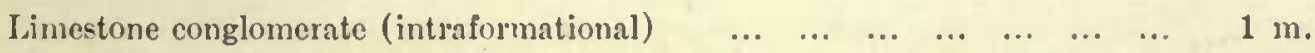

$\begin{array}{lllllllllllllllll}\text { Gray massive limestone } & \ldots & \ldots & \ldots & \ldots & \ldots & \ldots & \ldots & \ldots & \ldots & \ldots & \ldots & \ldots & 118 & \mathrm{~m} .\end{array}$

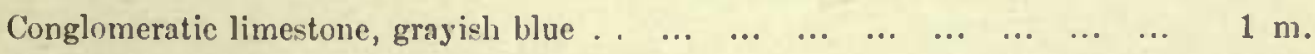

Pale grayish limestone in thin layers

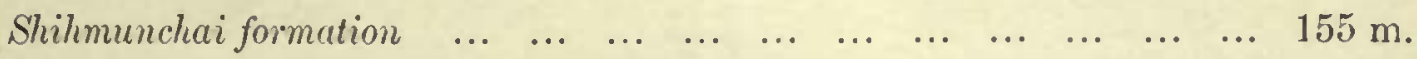

$\begin{array}{llllllllllllllll}\text { Interstratiffed sill } & \ldots & \ldots & \ldots & \ldots & \ldots & \ldots & \ldots & \ldots & \ldots & \ldots & \ldots & \ldots & \ldots & 6 & \mathrm{~m} .\end{array}$

*). The presence in this limestone in Shantung of Dalmanella ef Lesludinaria and Plectamboniles sericeus as recordes by Criek, Lorenz and Frech also suggests early Trenton, while Maclurea logani recorded by I.orenz again suggests the Black River, being known from that horizon in Canada as well as from Europe.

**). The straligrnpliy of this region will be more fully diseussed by Dr. Matibieu in a fortheoming Bulletin of the Survey. 


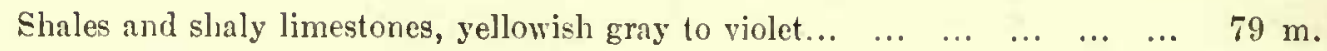

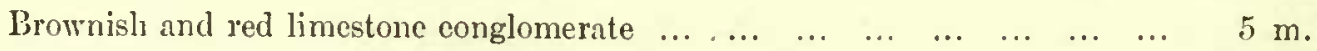

$\begin{array}{lllllllllllllllll}\text { Platey limestone } & \ldots & \ldots & \ldots & \ldots & \ldots & \ldots & \ldots & \ldots & \ldots & \ldots & \ldots & \ldots & \ldots & 17 \mathrm{~m} .\end{array}$

$\begin{array}{lllllllllllllllll}\text { Interstratified sill } & \ldots & \ldots & \ldots & . . & \ldots & \ldots & \ldots & \ldots & \ldots & \ldots & \ldots & \ldots & \ldots & 7 & \mathrm{~m} .\end{array}$

$\begin{array}{llllllllllllll}\text { Shales and shaly limestones } & \ldots & \ldots & \ldots & \ldots & \ldots & \ldots & \ldots & \ldots & \ldots & \ldots & \ldots & 22 & \mathrm{~m} .\end{array}$

$\begin{array}{lllllllllllllllllll}\text { Limestone } & \ldots & \ldots & \ldots & \ldots & \ldots & \ldots & \ldots & \ldots & \ldots & \ldots & \ldots & \ldots & \ldots & \ldots & \ldots & 5 & \mathrm{~m} .\end{array}$

$\begin{array}{llllllllllllll}\text { Brown shales and calcarenytes } & \ldots & \ldots & \ldots & \ldots & \ldots & \ldots & \ldots & \ldots & \ldots & \ldots & 13 & \mathrm{~m} .\end{array}$

$\begin{array}{lllllllllllll}\text { Brownish-red limestone conglomerate } & \ldots & \ldots & \ldots & \ldots & \ldots & \ldots & \ldots & \ldots & \ldots & & 1 & \mathrm{~m} .\end{array}$

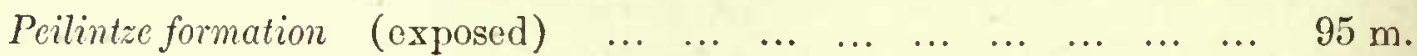

\begin{tabular}{lllllllllllllllll} 
Oölitic limestone & $\ldots$ & $\ldots$ & $\ldots$ &. & $\ldots$ & $\ldots$ & $\ldots$ & $\ldots$ & $\ldots$ & $\ldots$ & $\ldots$ & $\ldots$ & $\ldots$ & 23 & & \\
\hline
\end{tabular}

Bluish black massive limestone with fossil horizons F2, 10 meters and F1,

$\begin{array}{llllllllllllllll}33 & \text { meters below the top } & \ldots & \ldots & \ldots & \ldots & \ldots & \ldots & \ldots & \ldots & \ldots & \ldots & \ldots & \ldots & 72 \mathrm{~m}\end{array}$

Base not exposed

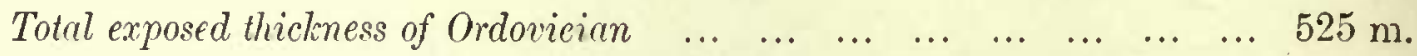

The most significant fact revealed by the study of this section is the absence of the Machialiou or Actinoceras limestone, which over such a wide area directly underlies the Carboniferous formations. This indicates a very pronounced pre-Carboniferous erosion in this region and further, a marked irregularity of attitude of the Ordovician strata, for a short distance to the south the higher limestones are present, and they are again found further to the north in Manchuria.

Peilintze Limestone. - A noteworthy fact is the apparent entire distinetness of the two faunas found in the limestones of this section. The fiuna of the lower or Peilintze limestone at present comprises the following species:

ACTINOZOA (?)

1 Archxocyathus (Archroscyphia) chilhliense Grabäu

GASTROPODA

2 Ophileta squamosa. Grabau

3 Fusispira sp.

CEPHALOPODA

4 Protocameroceras mattlieui Grabau

5 Chihlioceras nathani Grabau

6 Chillioceras chingwangtaoense Grabau

? 7 Piloceras platyrentrum Grabau (doubtful from this horizon).

The presenee of Archrocyathus in this fauma is noteworthy. This genus, and indeed all of the Archrocyathine, are typical of Cambrian horizons, occurring most 
commonly in the Lower Cambrian. One species however A. minganense Bill. has lieen obtained from the Lower Ordovician of the Mingan Islands eastern Canada. This species has no inner wall and has been made by Hinde the type of his new genus Archroscyphia. Our species is of the same generic type. The oceurrence of this fossil, which appears to he fitirly common, is sufficient indication that the Peilintze limestone represents lowest Ordovician. The presence of a Protocameroceras very similar to $P$. Irainardi of the American Beekmantown, further indicates the correctness of this classification, as does also the presence of Ophileta. Chillioceras represents a new type of cephalopod and for it the new family of the Chihlioceratide is erected. Its nearest relation is Piloceras, but it is very distinct from this in its siphuncular structure, which, curionsly enongh, is much more specialized and complicated than is that of Piloceras. The presence in this fauna of the species of the latter gemus, characteristic of the higher formation, is open to some doult, as it is possible that there may have been a mislabeling of specimens in the field. If it really belongs here, it is the only species which the two divisions have in common.

The base of the Peilintze limestone has not yet been found, and its relationship to the older horizons is therefore unknown. All of the material here described comes from tho lowest fossiliferous horizon (F 1) except one fragment which contains several specimens of Ophileta apparently of the same species as that in the lower horizon, though the material is rather imperfectly preserved. This comes from $\mathrm{F} 2$.

Lianchiasizan Limestove. - No fossils have been ol,tained from the intermediate shales and limestone of the Shihmunchai formation. The upper or Lianchiashan limestones carry a fossil horizon (F 3) 223 meters above the base. At this level the following species occur.

\section{GASTROPODA}

1 Ophileta plana Grabau

2 Hormotoma doquieri Grabau
CEPHALOPODA

3 Cameroceras styliforme Grabau

4 Piloceras platyventium Gralıau

This is a small but distinctive fauna, and one confined to this horizon unless the presence of Piloceras platyventrum in the lower beds should be sulustantiated. Both the Piloceras and the Ophileta indicate Lower Ordovician, or a horizon approximatehy equivalent to the upper Beekmantown of North America. Hormotoma indieates a somewhat higher horizon and the fauma may perbaps represent early Middle Ordovician, but can scarcely be higher so far as the known species permit us to judge.

The relationship of these fammas to the Ordovician fatunas of the Kaiping basin farther south, is still obscure. The beds which there rest disconformably upon the Upper Cambrian have so far furnished few fossils only, all of which are entirely unknown in either of the two horizons in the Shilh-mun-chai region. Further search may of course 
bring common species to light, and demonstrate the correspondence of the Yehli limestone series to one or the other of the formations in the more northern region. When such new material is obtained, it will be described in further numbers of this publication.

\section{DESCRIPTION OF SPECIES}

\section{Class ANTHOZOA \\ Family ARCHAEOCYATHINAE \\ Genus ARChaEOCyathus Billíngs \\ (Subgenus Archeoscyphia Hinde)}

\section{Archæocyathus (Archæoscyphia) chihliense Grabau (sp. nov.)}

Plate I Figs. 1-3

Caliculum irregularly sub-conical, apparently expanding in a uniform manner. Basal portion unknown. Adult portion sub-circular to sub-oval in transverse section, the latter possibly aceentuated by compression in some specimens. Septate portion (thecarium) thick, enclosing a hollow calieular cavity which, in the subeylindrical specimens, has a diameter something over one third the diameter of the entire caliculum. This cavity is well defined by the inner ends of the main septa, which attain a uniform length, but are not bounded by any definite inner wall, or endotheca. Outer wall or exotheca formed by the thickening of the outer ends of the septa, and their irregular confluence, the result being a very porous wall.

Septa thin, formed apparently by a series of small confluent trabeculie, this resulting in the production of thin radial plates of a very porous nature, so that in transverse section they appear as disconnected trabecule, disposed in radial lines. They are very numerous and arranged in groups of three or four each, the groups being separated by interspaces which are about twice as wide as the interspaces between the adjoining septa of a group. Oceasionally one of these broader interspaces is occupied by a short septum in the peripheral region.

A section $28 \mathrm{~mm}$. in diameter (PI I fig. 3), shows about 33 groups of septa, making a total of from 100 to 120 septa. The specimen from which this section is cut appears to have had a somewhat flaring outer edge to its calyx, a section of this showing on one side, because of slight obliquity of the cut. In this outer portion the septa are 
mostly continuous, very thin, and slightly serrate. They form a pronounced contrast with the inner portions of the septa which, in section, are discontinuous. Occasionally two of the outer septa become confluent.

The following are the measurements of this section:-

Longer diameter, exterior

, , interior

Thickness of thecarium

Thickness on opposite side

Transverse diameter, exterior

, , , interior

Thickness of thecarium

Thickness on opposite side

$\begin{array}{rl}36 & \mathrm{~mm} . \\ 13 & , \\ 16 & , \\ 7 & , \\ 28 & , \\ 11 & , \\ 8 & , \\ 9 & ,\end{array}$

$36 \mathrm{~mm}$.

13,

,

A specimen (Plate I, fig. 2), which evidently has been compressed laterally, has a present maximurn diameter on the exposed weathered surface of $80 \mathrm{~mm}$., while the shorter diameter is $40 \mathrm{~mm}$. A series of sections cut across this caliculum 25, 27 and 80 $\mathrm{mm}$. from the exposed surface, and parallel to it, shows so little difference in measurements that we must infer that the caliculum, in this part at least, was subcylindrical. These facts are brought out by a comparison of the following measurements. (Section No. 4 is nearest the top of the caliculum).

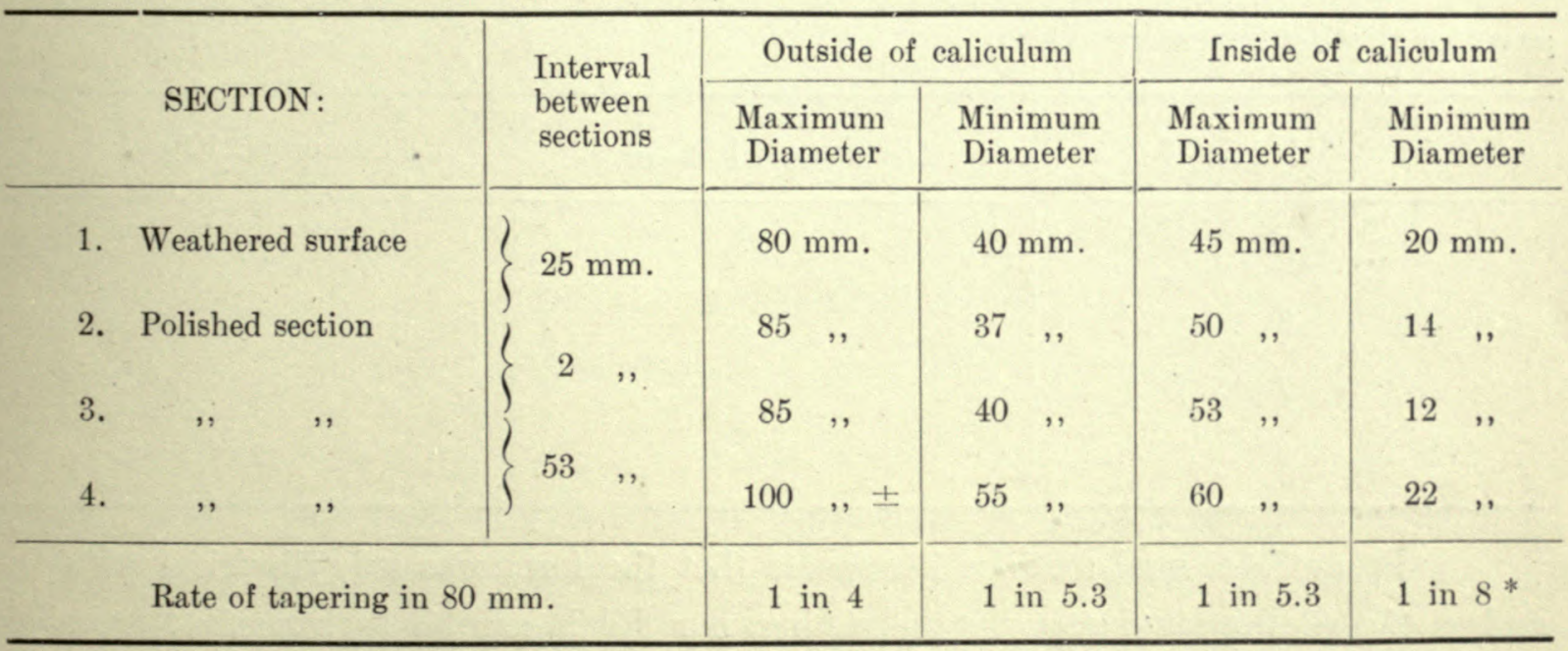

If the tapering was fairly uniform the length of the specimen must have been between 35 and 40 centimeters; actually it was probably about half that.

A third specimen, the largest obtained (Plate I fig. 1.) shows the following measurements on the exposed weathered surface and in a section $50 \mathrm{~mm}$. below this and parallel to it. The total length was probably $20 \mathrm{~cm}$. or over. 


\begin{tabular}{|c|c|c|c|c|c|}
\hline \multirow{2}{*}{ SECTION } & \multirow{2}{*}{ Interval } & \multicolumn{2}{|c|}{ Outside of caliculum } & \multicolumn{2}{|c|}{ Inside of caliculum } \\
\hline & & $\begin{array}{l}\text { Maximum } \\
\text { Diameter }\end{array}$ & $\begin{array}{l}\text { Minimum } \\
\text { Diameter }\end{array}$ & $\begin{array}{l}\text { Maximum } \\
\text { Diameter }\end{array}$ & $\begin{array}{l}\text { Mlinimum } \\
\text { Diameter }\end{array}$ \\
\hline 1. Weathered surface & $50 \mathrm{~mm}$. & $112 \mathrm{~mm}$. & $80 \mathrm{~mm}$ & $60 \mathrm{~mm}$ & $44 \mathrm{~mm}$. \\
\hline 2. Polished section & & $90 ?$, & 70, & 42, & $30 \quad$, \\
\hline \multicolumn{2}{|c|}{ Rate of tapering } & 1 in 2.3 & 1 in 5 & 1 in 2.8 & 1 in 3.57 \\
\hline
\end{tabular}

These measurements clearly indicate the gently tapering character of the caliculum and the variation in the thickness of the wall or thecarium vertically. We have no means at present of determining the length of the caliculum, but that it was very great is shown by the fact, that in one of the specimens there is so little variation in diameters in the known length of nearly $90 \mathrm{~mm}$. It is quite possible that this species grew to be over $30 \mathrm{~cm}$. in length.

There is considerable variation in the thickness of the wall around the periphery as shown in the sections. Measurements at four successive points around the periphery gave for three different specimens:

\begin{tabular}{c|c|c}
\hline Section pl. 1 fig. 3 & Section pl. 1 fig. 2 & Section pl. 1 fig. 1 \\
\hline 16 & 19 & 37 \\
8 & 12 & 16 \\
7 & 9 & 15 \\
\hline
\end{tabular}

From the several sections it appears that the form was subcylindrical with the surface of the thecarium scarcely undulating, nor did it exhibit such marked protuberances as characterize $A$. minganense, though scattered tubercles may have existed.

Comparisons. This species agrees with Archxocyathus minganense Billings in the absence of the inner wall of the thecarium. Its absence in $A$. minganense has been insisted upon by Hinde (1889) though Billings' figures (1862, figs. 343-344) indicate its presence (see also Roemer 1876, pl. II, fig. 2a, b). Because of the absence of the inner wall, Hinde erected for this species the new genus Archroscyphia. Hinde and subsequent authors (see especially Taylor 1910) were in error in believing $A$. minganense to be a Cambrian 
species. The Mingan Islands in the Gulf of St. Lawrence north of Anticosti Island, are composed of Ordoviciun strat:i, hoth Bcekmantown and Chazy being present, while Potsdan sandstone (possibly only a basal sandy phase of the Beekmantown rather than true Postdam) occurs on the mainland to the north. $A$ minganense and $A$. chilliense thus appear to be the last survivors of the Archaocyathine, which continued into the Lower Ordovician. Our species has a proportionately thicker thecarium than $A$. minganense, while the arrangement of the septa in groups of 4 or 5 further differentiate it from the American species. The strong annulations and nodes characteristic of the latter, are not developed in the Chinese form, or only slightly so.

Honizon axd Locality: This species was collected by Dr. F. F. Mathieu from the Peilintze limestone of Pei-lin-tze, Shih-mun-chai region eastern Chihli province, at horizon No. 1. It is associated with Ophileta squamosa, Cameroceras and Chillioceras. The age is Lower Ordovician.

\section{Cliss BRACHIOPODA}

\section{Order Protremata Beecher}

Family ORTHIDAE Woodward

Genus ORTHIS Dalman

(Emend. Hall and Clarke)

\section{Orthis calligramma Dalm.}

var. orthambonites von Buch (de Verneuil)

Plate 1. Figs. $\underline{4} a \cdot c, 5 a \cdot d$

1827 Orthis calligramma Dalman, Kon. Vet. Acad. Handl. p. 114, pl. 2 fig. 3.

15t5) Orthis calligramma de Vernenil, in Murch. De Vern. \& Kayserl. Geology of Russia and the Ural Mountains, Vol II, p. 207, plate XIII, figs. 7a-7f, and var. orthambonites von Buch, ibid. figs. $8 \mathrm{a}-8 \mathrm{~g}$.

1868 Orthis calligramma Davidson, British Silurian Bracbiopoda (Palaontographical Society Monographs), p. 240, pl. XXXV figs. $1-17$ (Bibliography and synonymy).

1853 Orthis calligramma Kayser, in Richthofen, China Vol. IV, p. 40, pl. III, figs. 10-13.

1901 Orthis calligramma var. scrica Martelli, Boll. della Soc. Geol., Ital. vol. XX, p. 297, pl. 4, figs, 1 -4; var daridsoni Martelli, idem. p. 301, pl. 45, figs. 5-6.

1913 Orthis calligramma Weller, in dVillis, Research in China, vol. III, p. 282, pl. 25, figs, $3-6$. 
Shell small sub-semicireular, wider than high, with the pedicle valve strongly, and the brachial valve more gently convex. Hinge-line forming the greatest width of the shell, cardinal angles rectangular, sides and front regularly rounded.

Pedicle valve somewhat sharply arcuate in transverse section, the greatest elevation between one third and one half the distance forward from the beak, which is elevited and very slightly incurved over the area. Cardinal area high, arelied, and of triangular outline, with a median triangular delthyrium which is higher than its basal width.

Brachial valve sub-semicircular, with a slightly salient beak which is not incurved. Cardinal area narrow, about one third as high, in the center, as the pedicle area. Contour depressed-convex, the greatest elevation about one third the length forward from the beak. A very faint median depression towards the front.

Surface of sleell marked by strong regular rounded plications, with deep interspaces alout equal in width to the plications in the earlier part, but wider towards the front. There are from 19 to 21 of them .on the pedicle valve, and a corresponding number on the brachial valve. The plications decrease very gradually in size towards the lateral margins, except on the cardinal extrenities where the last three or more are fine and narrow. Growth-lines very fine and rather obscure. In some specimens the plications become rather widely separated near the front, as their own widtli does not increase in proportion. This gives a very marked claracter to that part of the shell, as compared with specimens in which the plications thicken more in proportion.

The dimensions of a nearly complete small specimen (pl. I figs. 5a-d) are: height of pedicle valve $6.2 \mathrm{~mm}$., height of brachial valve $5.7 \mathrm{~mm}$., width of shell at linge area $8.5 \mathrm{~mm}$. Fragments of larger individuals also occur.

The numerous varieties currently classed under this specific name require a thorough revision, whein it will probably appear, that there are a number of distinct genetic series. The common Upper Ordovician (Caradocian) form of western Europe illustrated by Davidson in plate XXXV figs. 1 and 2, is strongly biconvex, and belongs probably to the genus Plectorthis which is derived from Orthis proper by the increase, among other features, of the convexity of the brachial valve, until in that respect it is essentially equal to the pedicle,valve. On the other hand, in more primitive mutations (primitive at least, so far as convexity of the brachial valve is concerned) the two valves are very unlike, and to this group our specimens belong. That transitional forms comnect the two series does not justify us in uniting them, for transitional forms between species of a genetic series are normal and to be expected. The increase in the size of the 
plications (or of the interspaces) is characteristic of a distinct evolutional direction, and the increase in number is equally characteristic of another, the two evolutional lines being divergent. Interpreted in terms of mantle growth, which is, after all, the key to the surface features of the shell, the regular increase in size of the plications without intercalation of new strix, signifies a uniform interstitial growth of the marginal or shellhuilding mantle-tissues, i. e. a uniform rate, and a uniform distribution of growth. The development of interealated plications on the other land, signifies a proportionately more rapid mantle growth of the portions corresponding to the interspaces, and this excess of growth has to be compensated for by a folding of the mantle, and the corresponding formation of plications. In other words, individuals with intercalated plications indicate unequal mantle growth, while those in which new plications are added only at the hingemargin, indicate relative uniformity of mantle growth. It is evident, that the two groups represent divergent lines of evolution. Our variety belongs to the latter group, and it is the one figured and described by de Verneuil as variety orthambonites, and it is to his figures $8 \mathrm{~b}-\mathrm{d}$, that our form most nearly corresponds.

The variety described by. Weller from eastern Szcehuan has fine radiating striae intercalated between the coarser ones, while that described and figured by Kayser from the "Light gray Brachiopod limestone of Kiau-tchang-pa," though larger, agrees in all essentials with the specimens from Chihli.

Horizon and Locality: In the upper part of the Machiakon (Actinoceras) limestone of Chaokouchuang in the Kaiping coal basin, eastern Chihli province. Collected by survey expedition.

\section{Family STROPHOMENIDAE King}

\section{Genus Strophomena Rafinesque}

\section{Strophomena cf incurvata (Shepard)}

Plate I fig. 6.

ef.1893 Strophomena incuriata (Shepard), Winchell and Schuchert. Paleontology of Mlinucsota, Vol. I, (With bibliography and synonymy.)

cf.1909 Strophomena incuriata (Shepard), Grabau and Shimer, North American Index Fossils, Vol. I, p. 223, figs. 271, a - d.

ef.1913 Strophomena sp. undt. Weller, in Willis. Research in China, Vol. III, p. 281, pl. 25, figs. 1, 2. 
At least one species of Strophonenoid shell allied to $S$. incurcata is common in the upper Machiakou limestone. It is of medium size, moderately concavo-convex, with the hingeline forming the greatest width of the shell.

Pedicle valve gently concave with a well developed hinge area. In some of the specimens the carliest stage of this valve, now forming the beak, is more or less strongly convex but this is usually a very small apical portion, and in some shells this is not shown at all. In consequence these suggest the characters of the brachial valve of a Rafinesquina. A specimen of this kind however shows a high hinge area, thus indicating that it is the pedicle valve, and that the generic reference is to Strophomena. Only half of the area is shown, but this is enough to show the triangular delthyrium partly covered by a rather short deltidial plate. The contour of the valve varies in different specimens from nearly flat to pronouncedly concave, the greatest concavity being in the anterior third.

Brachial valve strongly convex. No specimen has been observed in which the apical portion is depressed or concave, as is often if not generally the case in the genus. In some specimens the center of the valve is most strongly elevated, the sides being depressed-convex. Such a shell when small, has something of the aspect of a Dalmanella. In other specinens, the contour of the valve is regularly arched transversely, while the longitudinal contour shows the greatest convexity somewhat in front of the middle. In a few specinens the longitudinal contour is slightly undulating, due to frint and ill-defined concentric wrinklings, while near the front, the valve tends downward rather abruptly.

Surface narked by rather strong radiating striæ which increase in strength forward, and are multiplied by the intercalation of other strix. These are at first much finer, but also become strengthened towards the front, while at the same time other fine strix appear in the widening interspaces. Thus the aspect of the surface is that of strong striæ with from three to five finer ones between each pair of coarser ones. Very fine concentric lines cancellate the strixe and mark the interspaces, where they are strongest. They are very numerous and close-set.

The width of an avernge specimen is $14 \mathrm{~mm}$. the height $8 \mathrm{~mm}$. or more.

Horizon AND Localitirs: This is a common form in the massive dark-gray calcilutytes of the upper Machiakou limestone series at Chaokonchuang. As a rule the shells are closely crowded, and so much a part of the rock, that it is practically impossible to prepare the specimens, and observations are linited to the fracture exposures. Only in rare cases, where the rock has weathered upon the surface, is the shell visible in relief and preparation with the needle point is possible. 
Weller described similar shells as abundint in the Ki-su-ling limestone on the Til-ning River in eastern Szechuan, where they were collected by Blackwelder. His specimens indicate a somewhat larger size than our form, but appear to be of the same species. The reference of our species to the American S. incurvata is tentative, and indeed is probably not warranted. Better material is however necessary before it is possible to make a complete characterization of our form. It will probably be found to be in new species.

S. incurvata is a characteristic and abundant fossil of the Trenton limestone of New York and of the central United States, where it is widely distributed.

\section{Class PELECYPODA \\ Order Prionodesmacea \\ Family CTENODONTIDAE Hall \\ Genus CTEnodonta Salter}

Ctenodonta symmetrica Grabau (sp. nov.)

Plate I lijg. 7 .

Shell small, transverse, beak subcentral; hinge-line somewhat sharply arcuate, marked with rather strong transverse denticulations; ends subangularly rounded; ventral margin nearly straight. The anterior end is somewhat broader than the posterior, but the difference is not very pronounced. The anterior muscle-sear also appears slightly larger than the posterior, but again the difference is slight. It is however more strongly excavated than the posterior. There is a rather strong though low rounded ridge, extending from the posterior ventral margin of the anterior adductor scar towards the rostral eavity, dying away hefore it reaches this. Surface charncters unknown, but apparently the shell is marked by simple growth-lines.

This small shell has some resemblance to Ctenodonta logani Salter of the Black River of Wisconsin and Ontario, but the ends are more nearly equal and the denticulated hinge-line is more arcuate. The muscular impressions also are more pronounced, while the short internal anterior museular ridge is distinctive. From C. fecunda Hall of the Upper Ordovician (Maquoketa shale) it differs in the straight ventral margin, and the strong muscular impressions. It has the character of hinge, and of muscular impressions of C. pectunculoides Hall, of the Cincinnati group, but is of less rounded form. 
Hokizon and Locality: In the upper Machiakou (Actinoceras) limestone of Tangshan, associated with Lophospira, Pagodispira ete. Collected by Geo. B. Barbour. Only a single right valve of this species is so far known, this showing the interior, while the characters of the exterior are not visible.

The genus Ctenodonta is abundant in the Upper Ordovician of North America, where it is represented by many species. From Chinese rocks Ctenodonta has heretofore been reported only from the Lower Ordovician of Pupino in western Yunnan (CowperReed) but the species has not been identified.

\section{Class GASTROPODA * Order Rhipidoglossa Troschel Fanily EUOMPHALIDAE de Koninck Genus OpHILETA Vanuxem Ophileta plana Grabau (sp. nov.)} Plate II, figs. 1, 2a-b.

Shell with the spire flattened to a plane, except for a faint sub-narginal keel, the effect of which is to give the upper surface of the whorl, i. e. the shoulder, a faint concavity. There are about six volutions in what appears to be an adult specimen, the

* It is desirable to define the rarious terms here used somewhat more precisely, since there is some variation in their use. Spire is used in the usual sense for the spirally coiled portion of the shell above the last or body-urhorl. The angle formed by the convergent sides of the spire is the apical angle, the body-wharl being excluded where this enlarges more rapidly, or is separated from the earlier whorls. Whorl is used in a general sense for the elements of the spire and for the last or body-ichorl. Tolution is used more precisely for a complete coil, judicated by the lines of growth in juxtaposition on the two adjoining whorls. When the number of whorls is given it refers to the number of coils in the shell counted upwards from the body-whorl. In speaking of the first, second, third rolution, or when the statement is made, that such and sucb a change occurs at the end of $31 / 2$ volutions, or 4 rolutions etc. the measurement is always from the apical point or protoconch of the shell, the first rolution being completed by the line of growth opposite (next below) the apicat point. The whorls are separated by the sutures. A sutural shelf is a flattening of the succeding whorl below the suture. The subsulural sphal or carina lies at the upper edge of the next lower whorl, next below the suture. A sutural canal is a depression at the suture, a sunken sutural shelf. Spirals are fine rerolving ridges, a carina is a thickened rerolving ridge, which may be a single thick spiral or composed of sereral spirals. It generally forms an angulation in the shell whorl. The strong angulation of the whorl next betor the suture, is called the shoulder angle, and is measured in degrees. It is often emphasized by the peripheral carina, and forms commonly the most satient feature of the whorl. The space between the shoulder angle and the suture is the shoulder and it is usually flat or gently concare or faintly convex. It may slope upwards as in Lophospirn, at right angles to the axis of coiling as in Ophileta and Maclurea or downward, and inwards, when the spire is depressed, as in Excylioptemes. The part below the shoulder angle is the body of the whorl and it may contain one or more locer carint euch forming as a rule an angulation. They are numbered from the shoulder angle downwards (forwards). Ribs or costic are transverse rounded eleration marking temporary expansions of the whorl follorred by an equal contraction. If the expansion is suddenls abandoned, so as to leare an open forward-pointing or flaring portion of lip exposed, this is called a varir. It may be spinose, and it may be confincd to a single spine at the shoulder angle.

The degree to which the next whorl covers the preceding is ealled the amount of embracing of the whorls. When the amount is small, so that most of the preceding whorl shows, the spire is said to be loose-coiled, if nuel is corcred, it is close-coiled. If the whorls become separated from the earlier ones they are said to be laxly coiled. Ias coiling begins with the formation of a sutural canal or channcl. In trochiform shells the embracing extends to the shoulder angle. In a fer forms with sunken spire, it nay exteud above the shoulder angle. 
upper surfaces of which all lie at the same level, or are depressed so faintly as to be searcely noticeable. Side or body of the whorl at first vertical, thus making the shoulder angle 90 degrees. This vertieality is most marked in the last or body-whorl of the adult shell, whereas in the young, the contour quickly becomes rounded off inwards, this rounding being progressively more pronouneed in the younger portion of the shell. On the under or umbilical side, the inner whorls are probably depressed, though so far only weathered speeimens have been obtained, in which the whorls appear entirely flat. In these however the outer whorls are quite evidently worn down to the level of the inner. In a young specimen partly freed from the matrix, this depression of the inner whorls is indieated.

In an adult specimen, (Plate II, fig. 1) the greatest diameter of which is $24 \mathrm{~mm}$. the width of the final whorl (shoulder width) is $6.8 \mathrm{~mm}$. In a young specimen (pl. II. figs. 2a-b) with a maximum diameter of $14 \mathrm{~mm}$., the final whorl has a diameter of $4 \mathrm{~mm}$.

The most eharacteristic features of this species are: the flat surface of the spire formed ly the shoulder, the position of which is at right angles to the axis of the shell, and the submarginal earina. The lines of growth are not sufficiently shown in any of the specimens so far found to indieate whether or not there is a deep noteh upon the keel such as characterizes typieal species of Ophileta. Nevertheless the general characters are such as to make reference to the genus Ophileta most reasonable.

Of American species of the genus known to me, the present form eomes in many respects near to $O$. complanata, of the Beckmantown (Lower Ordovician). It differs however from that species in the flat spire, and the sunken or depressed umbilical area, Which in the Ameriean form is flat, while the spire is depressed and the whorls coneave. As in the Ameriean form, the upper keel is submarginal and the sides of the shell flat and nearly vertical, except in the lower portion, where they curve inwards in the Chinese species.

In general appearance the Chinese species is very like that deseriperl and figured by de Verneuil as variety A, of Euomphalus qualteriatus Salter, in the Palæontologieal volume of the great work on the Geology of Russia and the Ural Mountains (p. 334, pl. XXII, figs $2 \mathrm{a}, 2 \mathrm{~b}$, ), Indeed our form might be considered conspecifie with the Russian form (obtained from the Ordovician rocks of St. Petersburg), which is most certainly distinct from Salter's species. The two forms are very similar, except for the absence in the Russian form of the outer keel, which is distinctly shown in the Chinese species, and for the fact that the shoulder angle of the Russian form is less than 90 degress.

Horszox anb Locandry: This species was collected by F. F. Mathieu, geologist of the Kailan Mining Administration, in the Liangehiashan limestone at Liang-Chia- 
Shan, Shih-mun-chai (Shihmenchai) region near Chingwangtao eastern Chihli province (horizon F3). The formation is Lower Ordovician.

\section{Ophileta squamosa Grabau (sp, nov.)}

Plate II Figs 3-6

Shell with sunken spire, the whorls nearly in a plane but asymmetrical, gradually enlarging and in contact exeept, in some eases, in the last part of the final whorl. Umbilicus very large. Whorls with a gently coneave, slightly inward sloping shoulder, limited within by a blunt angulation and without by a rather sharp carina or keel, which is however not greatly elevated. Outer surface of whorl regularly convex, in such a manner that seen from above the carina is something less than one third of the width of the whorl within the periphery. Lines of growth eurving strongly backwards at the carina, forming a pronounced apertural notch at that point.

On the umbilical side the whorls are gently convex or slightly angular at the center with a pronounced but rounded carina next to the inner margin. On this side the lines of growth are very squamose projeeting at regular intervals, in the adult, in the form of small sharp varices. These die away at the outer margin, but continue on the inner carina and along the inside of the whorl to the point of contaet with the preceding whorl. Preceding the strongly squamose portion of the final whorl is a part where these squams have more the appearance of costre and are farther apart (plate II fig 4). This condition is still slightly visible on a portion of the preceding whorl.

The largest adult individual of this species found (pl. II fig. 6), has a maxinum diameter of $38 \mathrm{~mm}$. It is however a mueh worn specimen, and little can be added to the characters. The width of the final whorl of the aperture is $15.5 \mathrm{~mm}$., the enlargement being rather rapid in the last stage. The growth lines are strongly squamose projecting about. $0.7 \mathrm{~mm}$. from the sliell.

A section of another adult shell has a diameter of $36 \mathrm{~mm}$., but shows only the outer whorl (pl. II. fig. 5), the maximum diameter of which is $12 \mathrm{~mm}$., this being some distance behind the peristome. The outer surface of the shell is regularly rounded, from the keel of the shoulder angle to the margin of the umbilicus which is characterized by a faint rounded keel. The shoulder angle or keel lies about one third the distance in from the periphery of the whorl as seen from above and it forms nearly a right angle. The 
shoulder slopes strongly inward and is gently concave. The inner side of the whorl is rounded with a very faint suggestion of an impressed zone where it was in eontact with the preeeding whorl. The growth lines are squamose and erowded.

This species is of the type of Opliteta bella Billings which is found in the Beekmantown (Div P) of Newfoundland. The upper earina is however nearer to the outer margin in the Chinese speeies and the shoulder more regularly coneave. Again, the lines of growth are not squamose on the upper surface of the Chinese speeies, as they are in the Newfoundland form. On the umbilical side, the Chinese speeies is marked hy a rounded carina near the inner margin, this being absent in the Newfoundland species. On this side too, the growth lines are much more strongly squamose in the Chinese than in the Newfoundland form. Though related, these two forms are markedly distinet.

Horizon and Locality: This speeies was oltained by Dr. F. F. Mathieu from the Peilintze or lower limestone of the Lower Ordovician, at Pei-Lin-Tze, Shilumunchai, provinee of Chihli. It is not an uneommon form.

\section{Genus ECCYLiopterus Remele}

Eccyliopterus kushanensis Grabaı (sp. nov.)

Plate II Figs $7 \mathfrak{a}$ - c.

Shell of medium size consisting of about four volutions, which enlarge gradually and regularly. Spire sunken; umbilieal side nearly flat. Whorls of sub-rhomboidal section, the shoulder sloping inward, with a sharp shoulder angle, which was seareely elevated into the marginal "collar". Shoulder angle of the inner whorls somewhat greater than that of the outer ones, the shoulder itself sloping inward to a lesser degree than in the adult, and being flat, whereas that of the outer whorls becomes slightly coneave. The sucessive whorls embrace to within a very short distance of the shoulder angle, which, however, projects slightly in each whorl. Outer surfices of the whorls very gently convex, less so in the adult than in the earlier whorls, but not actually flattened. Towards the umbilical side the whorls beeome regularly rounded, and separated by depressed sutures. On this side the whorls are only very slightly depressed, so that a very large and very shallow umbilicus results.

This species is related to Eccyliopterus sinensis (Frech) (Raphistoma sinense Frech) from southern China. Comparison with a characteristie specimen from Hupeh, (Pl. II, fig. 8) shows it to be a flatter as well as larger shell. The whorls of the present 
species are not so high laterally as in $E$. sinensis, and the shoulder angle is somewhat less pronounced. The sides of the Hupeh form too are less convex, becoming almost flat in the last whorl, and the umbilicus is more depressed than in the northern species. In E. sinensis too, the embracing is much more pronounced so that each outer whorl rises, on its inner margin, above the shoulder angle of the preeeding whorl, whereas in $L$. kushanensis the shoulder of the outer whorl meets the whorl next within, a very short distance below the shoulder angle. This is shown in the sections on plate II. of which fig. 7 c represents the whorls of $E$. kushanensis and 8 d those of $E$. sinensis.

Horizon and Locality: The only specimen so far known comes from the Machiakou limestone of Ku-Shan, in Huo-Luh-Hsien western Chihli. This region has also furnished Actinoceras richthofeni from apparently the same horizon.

\section{Genus ECCYLiomphalus Portlock \\ Eccyliomphalus tangshanensis Grabau (sp. nov.)}

Plate II Fig. 9.

Shell large, laxly coiled, whorls not in contact, coiling essentially in a plane. Whorls rather rapidly enlarging from about $10 \mathrm{~mm}$. at the beginning, to $25 \mathrm{~mm}$. at the end of the final volution in the type specimen, in which only about one and a half volutions are preserved. Earliest whorls unknown. Under side broadly rounded, inner angle sharp and rectangular outer angle rounded. Upper surface unknown.

The speeimen exposes only the lower side of the whorls which is partly worn. Its large size (maximum diameter about $75 \mathrm{~mm}$.) and rapidly enlarging whorls are however very characteristic features. A section of a second specimen shows nearly two complete volutions but the final portion is crushed inward giving the shell a smaller proportional diameter. The diameter of the final volution is only about $18 \mathrm{~mm}$. at the end, and $7 \mathrm{~mm}$. at the beginning, giving about the same rate of enlargement. This specimen is worn down from the upper side. A comparison of the two specimens suggests an ovate-triangular cross-section of the whorls. Only a portion of the shell is preserved on the under side and this shows indistinct regular lines of growth. In general form and character, and in the rate of enlargement this shell suggests Eccyliomphalus undulatus Hall from the Stones River (late Middle Ordovician) of the central United States. It is however a much larger shell than any nember of that species with which I am acquainted. 
Horrzon and Localrtims; In the upper beds of the Machiakou or Actinoceras limestone, at Tangshan in the Kaiping Coal Basin, Chihli province, T. C. Wang coll. Also in the same formation at Huo-Luh, (Hwo-Luh) Chihli, Miss Clarke, coll.

\section{Family PLEUROTOMARIID $\boldsymbol{A}$ d'Orbigny}

\section{Genus LOPHOSPIRA Whitfield}

\section{Lophospira morrisi Grabau (sp. nov.)}

Plate III Figs. 1, 2a, b.

Shell of medium size for the genus. Spire consisting of about five angular whorls which embrace to within a very short distance of the peripheral carina. Apical angle 57 - 58 degrees. Whorls with flat or very gently concave shoulder, pronounced peripheral carina, obtuse shoulder angle, and faint lower carina. In well-preserved specimens, the shoulder angle is marked by a sharply rounded carnia with a narrow peripheral band on the outer edge of the shoulder, delimited by the peripheral carina and a fainter spiral above it. Lines of growth fine and sharp, beginning at the suture, where the shoulder is sometimes thickened as ly a faint subsutural carina. From this point the lines of growth bend backwards, at first very gently, then, as they approach the band, move abruptly, crossing the band with a distinet semilunar curve. In this respect the growth-lines and band are very similar to those of Liospira barbouri from the same horizon. They evidently indicate a rather pronouneed supra-marginal notch, a feature not usual in the genus Lophospira where the notch is generally at the peripheral carina.

The lower carina is faint and scarcely affects the contour of the body of the whorl; it may indeed be absent altogether.

Aperture sul-rhomboidal, the inner lip slightly reflected and covering the umbilicus.

Length of a perfect specimen (Plate III fig. 1), $17.5 \mathrm{~mm}$., greatest diameter of body whorl, $12.5 \mathrm{~mm}$.

This species is very sinilar to Lophospira medialis Ulrich and Scofield, from the Trenton limestones of New York and the central United States, the chief difference being the pronounced marginal band on the shoulder of the Chinese species, and its somewlint sharper peripheral carina. In other respects the two species are closely allied, and somewhat worn specimens of the Chinese species might readily be taken for the American form. 
Horizon and Locality: A nearly perfect specimen was olitained by Messis. Morris, Barbour and Terrill in the upper quarry beds of the Machiakou or Actinoceras limestone at Tangshan in the Kaiping coal basin eastern Clihli province. This specimen was associated in the same slab with Salpingostoma terrilli and Actinoceras tani. Another specimen, obtained by Mr. Geo. B. Barbour, from the same locality and horizon, is associated with Lophospira pulchelliformis and Pagodispira deviduii. These specimens are deposited in the Museum of the Survey. The speeific name is given in honor of Frederick K. Morris, Professor of Geology in Peiyang University Tientsin, in recognition of his active interest in the stratigraphic and structural problems of this country.

\section{Lophospira pulchelliformis Grabau (sp. nov.)}

Plate 1 II Figs. 3, 4.

Spire elevated, the apical angle about $60^{\circ}$, whorls embracing only to the lower carina which is strong and occupies the middle of the body of the whorl.

Shoulder flat or very gently concave, the shoulder angle about $90^{\circ}$, and marked by a rounded, well defined, peripheral band which occupies the apex of the angle, and is defined by an impressed line on either side. Lower part of whorl divided into two parts by the strong body carina which is rounded and nearly equal in strength to the shoulder angle. This earina is partly shown just above the suture in the earlier whorls. That part of the whorl between the shoulder angle and the lower carina is concave, while that below the earina is gently coneave near the carina but becomes gently convex towards the umbilicus, which is narrow. Lines of growth deflected backwards on the periphery, where they indieate a noteh of moderate depth.

This species is the Chinese analogne of the North American L. pulchella Ulrich and Scofield, which is found in the Black River horizon of the central States. The apical angle of our species is somewhat larger, being $60^{\circ}$ as against $50^{\circ}$ to $56^{\circ}$ in the Ameriean form. The lower earina in our speeies is also somewhat lower down on the whorl than in the American form. Nevertheless the two are very much alike.

Honizon and Localities: In the upper part of the Actinoceras or Machiakou limestone at T'angshan, several specimens, collected by Survey expedition; also one from the same section collected by Geo. B. Barbour. 


\section{Lophospira trochiformis Grabau (sp. nov.)}

Plate III Figs. 5a, 5̌b.

Shell with trochiform spire, the whorls embracing to the peripheral angulation. Shoulder concave, the periphery formed by a round band delimited by linear depressions above and below. Body of whorl without earina, concave below the peripheral band but convex for the greater portion; umbilieus small. A pical angle about $75^{\circ}$. shoulder angle $100^{\circ}$.

This species resembles $L$. morrisi, but is more strongly embracing, so as to entirely cover the preceding whorl. There is, further, no indication of an aceessory carina on the body of the whorl.

Horizon and Iocality: In the upper part of the Actinoceras or Machiakou limestone at Tangshan.

Lophospira acuta Grabau (sp. nov.)

Plate III Figs. 6.

Shell small, high-spired, apical angle about 57 degrees, whorls embracing to lower carina, which is pronounced and sharp. Shoulder coneave, characterized by revolving spirals, and forming an acute angle with the body of the whorl. Shoulder angle sharp. There are indications of rather sharply pronounced growth-lines which cancellate the spirals. Umbilieus minute.

This species differs from L. pulchelliformis, in the more acute shoulder angle, and in the sharp peripheral and lower carina. The apieal angle is also somewhat smaller in L. acuta than in L. pulchelliformis.

This species resembles in form, acuteness of whorl, and sharpness of carina the American L. acuminata (Ulrich and Scofield) from the Upper Ordovician (Riclimond) of the central United States, and like that form, appears to have strong growth lamella. Our species is however characterized by a ninute umbilieus, which is absent in the American species.

Honizon axd Localtry: This species was collected by the Survey party in the upper Actinoceras limestone (Nachiakou limestone) near Chaokouchuang, provinee_of Chilli (Kaiping coal basin). Its age is early Upper Ordovician. Cat. Mus. Geol. Survey Nos 47 and 48. 


\section{Lophospira gerardi Grabau (sp. nov.)}

Plate III, Fig. 7.

Shell of less than medium size, with an apical angle of 65 to 70 degrees. Whorls embracing to a point about midway between the two carine, exposing the lower portion of the whorl for an amount equal to about half the shoulder width. Shoulder flat to very gently concave, with a well-marked peripheral carina, bordered above and below by a distinct spiral line. The upper of these spiral lines is separated from the median carina by a distance about twice that between the carina and the lower bordering spiral, produeing the appearance of a peripheral band on the margin of the shoulder. Shoulder angle about $95^{\circ}$. Lower carination generally well marked, its distance from the periphery being somewhat less than the width of the shoulder. The space between the two carinations is gently concave or nearly flat, while below the lower carina, the whorl slopes rather abruptly to the umbilical region. Aperture subquadrate; umbilicus not observed.

Lophospira gerardi has many of the characters of $L$. perangulata Hall, from the Stones River and Lowville-Black River groups, of the central United States, New York, and Canada, the chief differences being the greater apical angle of our species. In the American form the final whorl is also often laxly coiled, and the peripheral carina is trilineate.

Horizon and Locality: This species and its variety were found by the Survey expedition in the Machiakou or Actinoccrns limestone of the Chaokouchuang region in the Kaiping coal basin. The specific name is given in honor of M. Jaques Gérard, geologist and engineer of the Chaokouchuang mines of the Kailan Mining Administration.

\section{Lophospira gerardi}

variety laxa Grabau (var. nov.)

Plate III, Fig. 8.

This is a gerontic mutation of $L$. gerardi. The early whorls are slightly more embracing than in the normal form, making a greater apical angle (nearly 80 degrees), but the later whorls become slightly separated, producing a lax-coiling adult. This results in a pronounced sutural channel, bounded without by the sliarp upper angle of the 
shoulder. The shoulder itself at the same time becomes more pronouncedly concave, and the peripheral carina becomes more prominent. The trispiralled character of the peripheral carina is still maintained, with the median spiral thickest, but the lower spiral becomes more distant, so that the space between it and the median one is slightly wider than that between the median and upper spirals. The space between the peripheral and lower carina has also become more pronouncedly concave. Umbilicus not observed.

Horizor axn Locality: Occurs with the preceding.

\section{Lophospira terrassa Grabau (sp. nor.)}

Plate III, Fig. 9.

Shell of medium size, and somewhat robust aspect; apical angle ahout 62 degrees. Earliest whorls not preserved. Neanic whorls with a shoulder angle of about $95^{\circ}$ which in the adult becomes between 100 and $110^{\circ}$. Whorls moderately embracing, leaving the body exposed to a height equalling about half the shoulder width, or somewhat less. Shoulder moderately convave, with a broad and rather ill-defined upper (subsutural) carina and a well-defined sutural shelf or terrace, which.is flat or may slope slightly inwards. Shoulder angle marked by a rounded carina bounded by impressed lines. Body of whorl, below shoulder-angle, gently convex, without lower carina. Lines of growth sharp and crowded, bending at first gently backwards on the shoulder, and then crossing the periphery with a pronounced backward curve. After crossing the periphery, they bend forward, and then more abruptly downwards. They thus indicate a pronounced peripheral notch. Axis with a minute median hollow, as seen in the broken apex. Diameter of final whorl $15 \mathrm{~mm}$.

This species differs from $L$. gerardi in the absence of the lower carina, and in the terrassiform sutural shelf. From $L$. morrisi it differs in the presence of this shelf, and the lesser amount of embracing. It is closely related to Lophospira ampla Ulrich of the Lorraine and Richmond (Upper Ordovician) of the central United States, but that species has a less developed subsutural shelf, and the whorls embrace somewliat more, giving the shell a slightly greater apical angle. The two species are however very similar.

Honizox axd Locality: In the Machiakou limestone oi Tangshan, Chihli. Survey collection. 


\section{Lophospira obscura Grabat (sp. nov.)}

Plate III Fig. 10

Shell turreted, consisting of about 5 whorls which expand rapidly and are angulated by a pronounced shoulder angle and a less marked lower carina. Apical angle about 60 degrees. Shoulder flat, bounded below by a heavy carina and embracing to the lower carina of the preceding whorl. Exposed part of the body of the preceding whorl somewhat less than the width of the shoulder. Shoulder angle about 115 degrees, characterized by a rather strong rounded carina or keel. Lower carina moderately strong, the surface of the whorl between it and the shoulder angle being flat or slightly concave. Below the lower carina the whorl is rounded. Umbilicus apparently closed. Surface characters not ascertained.

In its genfral form and character this species resembles L. bicincta of the Stones River and Trenton groups of the central United States, but it is without the marked carina near the upper end of the shoulder. That is however faint in some cases in the American species. It differs from $L$. gerardi in the greater shoulder angle, smaller apical angle and less degree of embracing.

The mold of the interior of our species presents rounded outlines owing to the thickening of the shell on the interior.

Horizon and Locality: In the Actinoceras beds of the Machiakou limestone at Tangshan. Collected by Survey expedition.

\section{Genus Pagodispira Grabau (gen. nov.)}

Shell with comparatively small apical angle and subrectangular whorls, giving the shell a pagodiform aspect. Whorls without slit, but bearing a peripheral earina like that of Lophospira. One or more additional carine may be present. Aperture subquadrangular to trapezoid, generally with a faint anterior emargination. Umbilicus generally covered by the reflexed inner lip.

This genus is closely related to Lophospira from which it differs primarily in the much drawn-out form of the spire, and the resultant small apical angle. It may indeed be regarded as a more primitive branch of the Lophospira series in which the whorls embrace only to a very small degree, or better as a lateral branch from the ancestral stock, in which the embracing of the whorls remains in the primitive state. This is suggested by the fact, that in other gastropod series the more specialized members show a larger amount of embracing, while further, members of a degencrating series, show a. 
tendency towards a decreasing amount of embracing in the adult, which in certain cases is followed by a loosening or laxness of the coil.

Genotype: Pagodispira derwiduii Grabau, Ordovician.

Of foreign species referable to this genus, we may mention Pagodispira boudeni (Safford) from the Upper Ordovician of North America. So far as known the genus is confined to the Ordovician.

\section{Pagodispira derwiduii Grabau ( $\left(\mathrm{p}_{1}\right.$. nov.)}

I'late III l'ig. 11 .

Shell slender, with the apieal angle varying from 28 to 32 degrees; whorls 8 to 10 (at least 9 in the holotype) angular, and divided near the center of the exposed part by a sharp peripheral carination which consists of a median strong rounded spiral, closely flanked by a fainter and mucl weaker spiral on each side. Shoulder gently concave, apparently smooth, though there is a suggestion of faint spiral lines. Shoulder angle varying from about 95 degrees in the young, or in more retarded individuals, to about 112 degrees in the adult. Exposed portion of whorl below the shoulder angle of the same width as the shoulder, and like that gently concave. A lower carina, situated just below the suture of the whorls is present at least in the adult portion, where it is of moderate strength on the body-whorl. Umbilicus covered by reflexed inner lip. Length of holotype about $35 \mathrm{~mm}$. (the apex is imperfect), dianeter of last whorl $14 \mathrm{~mm}$.

This species differs from the American P. boudeni (Safford) (Lophospira boudeni Ulrich and Scofield) from the Lorraine and Richmond of the central United States, in the sharper shoulder angle (that of $P$. boudeni being from 122 to 125 degrees) and in the more strongly concave shoulder, that of $P$. bowdeni becoming convex near the suture, forming an obscure carina. The whorls of our species also embrace to a lesser degree than is the case in P. bowdeni, where the part below the periphery is only about two thirds as wide as the shoulder. Finally the Chinese species has a sharper peripheral carina and a stronger lower carina, the latter in $P$. bowdeni being faint or alsent. From $P$. dorothea Grabau, it differs in the sharper shoulder angle and peripheral carina and the lesser degree of emluracing.

Honizor axd Locatutres: In the Machiakou or Actinoceras limestone near Chaokouchuang in the Kaiping conl basin, Chihli province. Collected by the Survey expedition. Also in the same horizor at Tangshan, collected by George B. Barbour. 
The specifie name is given in honor of M. Maurice Derwidnee, chief of the Chaokouchuang mines, whose interest in, and recognition of the practical value of geological and palæontological seience, has contributed not a little to the distinguished success of the great mining operations under his charge, and who gave us every facility and aid in his power, in our investigation of the stratigraphy and palrontology of the Chaokouchuang region.

\section{Pagodispira dorothea Grabau (sp. nov.)}

Plate III Fig. 12

High spired, with apical angle of about 24 degrees; consisting of about 8 angular whorls. Shoulder flat or very gently coneave, without change of slope at suture; shonIder angle in the young whorls about 90 or 95 degrees, increasing in the adult to $117^{\circ}$ degrees. Exposed portion below peripheral earina, about two thirds as wide as the shoulder in the adult, apparently more nearly equal to it in the young; flat, or appearing slightly coneave because of the strong peripheral earina, which is somewhat thickened. Lower carina strong, situated at the suture, and exposed in the penultimate whorl, because of the slight separation of the final whorl.

The species differs from $P$. derwiduii in the greater shoulder angle and more pronounced embracing of the adult whorls, as well as in the laxity in growth of the final whorl. From P. bowdeni it differs in the character of the shoulder and in the sharper peripheral, and stronger lower carinæ.

Honizon and Locality: In the upper Machiakou or Actinaceras limestone of Tangshan. The specific name is given in honor of Mrs. Dorothy Dickinson Barbour, wife of Prof. George B. Barbour the discoverer of the holotype, and by whom it was presented to the museum of the Survey.

\section{Pagodispira dorothea var. laxa Grabau (var. nov.)}

Plate III Fig. 13

This variety differs from the species in the laxness of coiling characteristic of the whorle. This is shown in the submature whorls ly the fact that the lower carina shows above the suture and in the last whorl by actual looseness of the whorl. The apical angle is about 18 degrees. The lower carina is strong. 
The earlier whorls, some of which are shown on the same rock fragment, have the normal character of the young of $P$. dorothea, which is also essentially like that of the adult $P$. derwiduii.

Horizon and Locality: This variety occurs in the upper beds of the Machiakou or Actinoceras limestone of Chaokouchuang, where it was collected by the Survey party.

\section{Genus LiOsPiRA Ulrich \& Scofield Liospira barbouri Grabau (sp. nov.)}

Plale III, Figs. 14a, b., 15a-c.

Shell of medium size but somewhat higher spired than in the majority of species of that genus. Height of spire somewhat variable, the apical angle ranging from $110^{\circ} \mathrm{in}$ the lowest to $95^{0}$ in the highest spired individual. Whorls subrhomboidal, with a gently coneave shoulder and a sharp shoulder angle which varies from $60^{\circ}$ in the more strongly conical to $55^{0}$ in the more depressed forms. Lower part of the whorl very gently convex or alnost flat; with a sharp angle at the rather large umbilicus.

Peripheral band on the outer margin of the shoulder fairly well defined by a low but sharp carina or spiral, the succeeding whorl embracing to the outer edge of the peripheral band, i. e. to the shoulder angle; so that the suture is not depressed. Lines of growth nearly vertical or slightly oblique backwards in the upper half of the shoulder, after which they are strongly deflected backward to the peripheral band which they cross with a definite curve, producing a pronounced marginal notch (Plate III, Fig. 15c). Aperture not fully preserved in the known specimens.

This species has the rather flat base and subtrochoidal form of a Euconia, but the sharp shoulder augulation, the usual concavity of the shonlder, the large umbilicus with angular margins, and the slightly defined band on the peripheral margin of the shoulder, indicate its relationship to the genus Liospira. The character and position of the peripheral band, and the deep noteh are features also suggestive of Luconia.

I am not acquainted with any American or European species with which this species is likely to be confounded. It has many of the characters of L. vitruvia (Billings) of the Middle and early Upper Ordovician (Stones River to Trenton) of Canada and the United States, but the spire is higher and the apical angle thejefore less, in our species, while the shoulder angle of our form is also sharper and the lower part of the whorl flatter. 
Measuminasts. The following are the measurements of the types:

$\begin{array}{cc}\text { Diameter of } & \text { Diameter of } \\ \text { body-whorl } & \text { umbilicus }\end{array}$
1. (Fig 14), $12.5 \mathrm{~mm}$.
19. $5 \mathrm{~mm}$.
5.5
2. (Fig 15), 11. $5 \mathrm{~mm}$. (approx.)
20. $0 \mathrm{~mm} . \pm$
6.

Horizon and Locality: In the upper portion of the Actinoceras or Machiakou limestone at Tingshan, provinee of Chihli. Collected by George B. Barbour, Professor of Geology in Peking Christian University, in whose honor the shell is named. Also Survey collection.

\section{Family MURCHISONIDA Koken}

Gents HoRMOTOMA Salter

\section{Hormotoma doquieri Crabatll (sp) nov.)}

I'ale III Figs. 16a-b

Shell small, high spired with 7 or more whorls (the apex is imperfect), which embrace very slightly, leaving the larger part of the preceding whorls exposed. Apical angle about $16^{\circ}$. Shoulder flat or gently convex. Shoulder angle obtuse, characterized by a revolving band, which is bordered by a spiral on either sicle. Lower part of whorl rounded, and broader than the shoulder. Lines of growth prominent, producing in subdued surface ornamentation. Aperture not fully shown, but apparently with an anterior notcls.

This shell has the general character of Hormotoma gracilis Hall, from the Clazy and Stones River, and the Trenton of North America, but the shoulder is flatter in the Chinese form and the lower exposed part of the whorl proportionately higher than in the American species. The lines of growth are also more prominent in the Chinese form.

Horizon axd Locality: In the Liangehiashan limestone of the Shih-Mun-Chai region, eastern Chihli province, collected by F. F. Mathieu. The specific name is given in honor of M. Alexandre Doquier chief of mines of the Kailan Mining Administration. 


\section{Fanily BUCANIDAE Ulrich \& Scoficld}

Gemus Salpingostoma Rocmer

\section{Salpingostoma terrilli Grabau (sp, nov.)}

Plate II, Figs. 10a-c

Shell bellerophontoid with rather rapidly enlarging whorls, coiled in a single plane; the earlier whorls embraced by the later, so as to produce a rather small and deep umbilicus. Outer contour of whorls rounded, exeept where this is interrupted hy the pronounced slit, the sides of which are slightly elevated. Apertural portion suddenly and flaringly expanded into a broad bellerophontoid lip, which extends on all sides of the whorl, and eloses the slit in front. Surface markings not preserved.

The only specimen so far known is crushed on one side and on the front, but shows all the essential characters of the genus. The slit is wider than is usually the case in this genus and its borders are somewhat thickened. How much of this is due to silicification cannot be stated.

Compared with other species of this genus, the whorls of this form expand more rapidly and embrace nore closely; thus giving a much smaller and deeper umbilicus than is usually found in this shell. The lip also appears to be broader and more extended than in other species. This genus is well represented in the Stones River (Chazy), and Black River formations of interior Nortl Ameriea and in the Trenton of New York and Canada. It also extends into the Richmond group of the highest American Ordovician. The genus is further well represented in the Upper. Ordovician of Esthonia (formations C1, C2 and F1)

Our species is more nearly of the type of those found in the Echinospharites limestone (C1) of Europe and those of the Trenton limestone of Ameriea, but is distinet from all of these forms.

Hontzon and Locality: Associated with Lophospira morrisi and Actinoceras tani in the upper Machiakou or Actinoceras limestone of T'ungshan, province of Chihli. At present represented by only one specimen. Collected by Messrs. Morris, Terrill and Barbour.

Holotype in the collection of the Chinese Geological Survey, Cat. No 32. Named after Mr. Arthur C. Terrill, Professor of mining in Peiyang University, the discoverer of the specimen, 


\title{
Order Ctenobranchiata Schweigger \\ Family PYRAMIDELLID $A$ Gray \\ Genus Fusispira Hall
}

Fusispira sp.

Plate III, Figs. 17, 18.

Among the material collected by M. Mathieu from the Peilintze limestone, are two specimens of a gastropod, which, from the general form of the spire and the contour of the whorls, is referable to the genus Fusispira. The apical angle is 11 or 12 degrees, and the shell consists of about 10 whorls if not more, the apical portion of both specimens being imperfect. The whorls are of somewhat greater diameter than their length, uniformly rounded, and gradually enlarging. The amount of embracing is slight, producing a loose-coiled shell, with a deep suture, which is very oblique, and forms an angle of 51 to 57 degrees with the axis of the shell. Character of aperture and nature of surface markings not ascertained.

This shell has the general form and proportions of Fusispira angusta Ulrich and Scoficld, from the Trenton of the central United States, but the apieal angle of the Chinese species is smaller by perhaps 5 degrees, the whorls shorter, and the suture deeper.

Horizon and Locality: In the Peilintze limestone of the Shih-Mun-Chai region, associated with Oplileta squamosa. Collected by F. F. Matlieu.

\author{
Class CEPHALOPODA \\ Order NAUTILOIDEA Zittel \\ Suborder Holochoanites Hyatt \\ Family ENDOCERATID $\boldsymbol{E}$ Hyatt \\ Genus Proterocameroceras Ruedemann \\ Proterocameroceras mathieui Grabat (sp. nov.)
}

Plate 1V, Figs. 1-3

Orthoceracones of unknown size, represented so far only by fragments, which suggest that the shell had a length of a foot, and probably much more. Moreover the fragments may represent only the earliẹ part of the conch. 
Shell oval in section, the largest fragment known having a derso-ventral diameter of $23 \mathrm{~mm}$., while the transverse diameter is something over $30 \mathrm{~mm}$. At the same point the siphuncle has a diameter of 12 and $15 \mathrm{~mm}$. respectively, thus being at this stage about one half the size of the shell. The ventral side is distisctly flattened, this being shown both in the shell and in the siphuncle, which lies in close juxtaposition to the flat ventral sicle of the shell. The thickness of the shell-wall at this point is half a millimetre. The camer:e average $3 \mathrm{~mm}$. apart at this stage, and their concavity, as nearly as can be ascertained, is equal to about twice their distance apart at the center, or a little more.

Siphuncle distinctly flattened on the ventral side where it is in contact with the shell, the flattened part in the apical portion of the largest specimen being $9 \mathrm{~mm}$. It tapers at the rate of about $1 \mathrm{~mm}$. in 16 . There is a well-defined and distinct wall, which cncloses the siphuncle (endosipholining of Ruedemann). This siphuncular wall or inner shell is obliquely annulated by the edges of the siphonal necks, which are slightly but distinctly constricted just before reaching the next lower septum. The suture forms a distinct ventral saddle on the flattened surface of the shell. The anterior empty portion of the siphuncle (the endosiphocylinder of Ruedemann, i. e. the inner living-chamber) is broken away to the edge of the last-formed endosiphoshenth (inner conical septum). The depth and apical angle of the endosiphocone, delimited by this last sheath, cannot bo ascertained, but the former is at least 20 or $25 \mathrm{~mm}$. which would make the latter about $25^{\circ}$. The interior of the siphuncle below this cone is filled by crystalline calcite which has a distinct radial structure as in belemnites. In its center or nearly so, lies the subtriangular endosiphocoleon, flattened on the ventral side to correspond to the flat ventral fice of the siphuncle. Its ventral diameter at the lower end of the specimen is about $2.5 \mathrm{mim}$.

Another specimen (Plate IV fig 2a-c) shows an earlier portion of the shell, apparently of a different individual. The shell is strongly oval, the maxinum transverse diameter being $18 \mathrm{~mm}$. while the dorso-ventral diameter is only $11 \mathrm{~mm}$., though the shell appears to be somewhat crushed dorsally. The corresponding diameters of the siphuncle are 8 and $7 \mathrm{~mm}$. respectively.

The septa are a little over $1 \mathrm{~mm}$. apart. The siphuncle is in close juxtaposition to the flat surface of the shell, which is about $6 \mathrm{~mm}$. wide. The sides of the siphuncle are olliquely annulated by the septal necks, which form an angle of $70^{\circ}$ with the ventral surface of the siphuncle, this being essentially the angle formed by them in the larger specimen. The endosiphocoleon lies somewhat dorsad of the center. Rate of tapering of siphuncle $1 \mathrm{~mm}$. in 26. 
On the exterior of the shell there appear to be broad very shallow and ill-defined concentric constrictions, but these are observed only on the ventral side, the rest of the shell not being visible.

Three fragments of the collection appear to represent parts of $a^{-}$single siphuncle of this species (Plate IV fig 3a-c). This is long and slender, but its entire length is not known, though the fragments preserved indicate a length of over $80 \mathrm{~mm}$. At the smallest end preserved, the diameter is $6.5 \mathrm{~mm}$, at the largest $9 \mathrm{~mm}$. The rate of tapering is about $1 \mathrm{~mm}$. in 25 . The youngest fragment is slightly flattened ventrally and shows broad ill-defined undulations. It has a sub-central endosiphumele, and the organic limefilling (stereoplasm) of the remainder is obscurely radiate. In the larger fragments, the shell is cireular in section, and appears entirely smooth, and is half a millimeter in thickness. In'certain positions, however, very faint oblique lines are visible, suggesting septation. Within it, is at least one well-defined thick-walled conical sheath, tapering at the rate of $1 \mathrm{~mm}$. in 10. Around this the crystalline lime has a radiating structure. The interior of the cone, formed by the sbeath, is also filled with crystalline calcite, except at the larger end (3b), where an open semilunar cavity exists, due to removal of softer filling. At the upper end of the largest fragment this has a vertical diameter of $1.6 \mathrm{~mm}$. and a basal width of $4.8 \mathrm{~mm}$. On the other side of the fragment, which is $20 \mathrm{~mm}$. long, this semilunar tube, here still retaining its filling, has been reduced to about half these dimensions. The structure of the interior filling of caleium carbonate is also raiiate. The presence of three other sheaths is indicated by concentric tubular interruptions of the crystalline (generally radiate) lime-filling, but these were exceedingly thin walled, possibly membranons. *

Except for the very faintly indicated oblique ridges these siphuncular fragments suggest the preseptate apical end of Proterocameroceras, and for such they were at first taken. This is also suggested by the circular cross-section, but on the other hand, their size agrees with that of the siphuncle of the species where still surrounded by the camere (Plate IV fig, 2).

Horizor and Locality: This speeies occurs in the Lower Ordovician Peilintze limestone of Pei-lin-tze, Shih-Mun-Chai region near Chingwangtro eastern Chilhli. It is associated with Chihlioceras, Archrocyathus ete. Collected by F. F. Matlieu, in whose lonor the specific name is given.

* This supports Ruedemann's contrniion that endoshaaths aro present in Cameroceras (including Proterocameroceras), below the final thick-ralled shcath of the adult living chamber. At least ore of these in the prescnt specimcn, is thickwalled and of well defined character. 


\section{Genus Cameroceras Conrad (emend. Hyatt)}

Cameroceras styliforme Grabau (sp. nov.)

Plate IV Figs, $4 \cdot 6$

A small slender siphuncle of Cameroceras occurs in the upper or Liangehiashan beds but no portion of the shell remains in the specimens so far obtained.

A specimen (Plate IV fig. 4) measuring $30 \mathrm{~mm}$. in length, and of suboval section, measures $3.5 \mathrm{~mm}$. in transverse, and $2.5 \mathrm{~mm}$. in dorso-vental diameter at the lower end. The corresponding measurements at the upper end are $6.6 \mathrm{~mm}$. and $4.8 \mathrm{~mm}$. respectively. The vental side is distinctly flattened. The siphuncle was evidently enclosed by camerse. Their distance apart near the upper end, as shown by the annulations, was $2.2 \mathrm{~mm}$. and the angle which these annulations form with the ventral line of the siphuncle is about 68 degrees. Wall of siphuncle of moderate thickness; interior filled with crystalline calcite, but showing in the center, at the smaller end of the siphuncle, an empty endosiphocoleon of semi-lunar section, its flat base corresponding to the flat side of the siphuncle. The width of this side is $1.3 \mathrm{~mm}$. while its dorso-ventral diameter is $0.5 \mathrm{~mm}$. (Plate IV fig. $4 \mathrm{~b}$ ). There are three other lumens irregularly placed around the periphery, but equi-distant from the outer wall, indicating that they represent part of an endosiplosheath. *

Another fragment (Plate IV, figs. 5a-c) representing a larger portion of the siplunncle, measures 7.3 and $5.9 \mathrm{~mm}$. respectively in lateral and dorso-ventral diameters. The ventral side is not so much flattened, but is more broadly rounded than the dorsal. The siphuncle at this point was not absolutely in contact with the shell, for the septal odges form a distinct, broad, rounded saddle upon the ventral side. Septa $2.2 \mathrm{~mm}$. apart. Siphuncular wall (silicified) rather thick, the interior filled with crystalline caleite, except for a central sheath of similar section as that of the wall of the siphuncle, and like that, silicified. Its diameters, at the upper end are: lateral, $5 \mathrm{~mm}$., dorso-ventral, $3 \mathrm{~mm}$., the dimensions of the siphuncle at this end being 7.3 and $5.9 \mathrm{~mm}$. respectively. At the other end, $8 \mathrm{~mm}$. distant, where the dimensions of the siphuncle are 6 and $5 \mathrm{~mm}$. the inner tube measures 3 and $1.8 \mathrm{~mm}$. respectively. Thus, while the lateral tapering of the siphuncle is $1.64 \mathrm{mn}$. in $1 \mathrm{~mm}$. and the dorso-ventral tapering $1.12 \mathrm{~mm}$. in $1 \mathrm{~mm}$., that of the inner tube is 2.5 and 1.5 in 1 , respectively.

A third specimen (Plate IV figs. 6a-c) represents a still larger portion of the siphuncle of apparently the same species. Its length is $13 \mathrm{~mm}$., while the diameters at 
the larger end are 10 and $9 \mathrm{~mm}$., and the corresponding measurements at the smaller end 8.2 and $8 \mathrm{~mm}$. respectively. The corresponding measurements of the endosiphuncle are: - upper end, $5.7 \mathrm{~mm}$. and $4.7 \mathrm{~mm}$., lower end, $2.5 \mathrm{~mm}$. and $2 \mathrm{~mm}$., respectively. Although somewhat compressed, there is no flattening of the siphunele and the septal ends, which still adhere to the siljeifield siphuncle, form only a very gentle obliquity with its axis. This indicates that the siphuncle at this stage was no longer in contact with the wall of the shell, but had been surrounded by the cameræ on all sides, including the ventral. This is further shown by the fact that the ends of the septa still remaining, are stronger on the ventral side (side of forward convergence) than elsewhere. The septa average about $2 \mathrm{~mm}$. apart.

In spite of the variations here shown, I am disposed to think that we are dealing with one species only. This is however quite distinct from the species found in the lower İorizon (i. e. Proterocameroceras mathieui).

Horizon and Locality: A number of fragments were obtained by Dr. F. F. Mathieu from the upper or Liangehiashan limestone of Liang-Chia-Shan, near Chingwangtao, eastern Chihli. The age is late Lower or perhaps early Middle Ordovician. Geol. Survey collection cat. nos. 103 to 107 .

\title{
Genus Suecoceras Holm
}

\section{Suecoceras yehliense Grabau (sp. nov.)}

\author{
Plat IV, Figs. 7a, b.
}

Represented only by the apical portion of the endosiphuncle which shows the slight but distinct inflation characteristic of the genus. The most perfectly preserved specimen (Plate IV, fig. 7), has a length of about $40 \mathrm{~mm}$. Its apex is pointed and its diameter increases rapidly at first, then more slowly, until at a point about $20 \mathrm{~mm}$. from the apex, it has a diameter of $13.2 \mathrm{~mm}$. Then it decreases slowly, its diameter at the upper end of the specimen being $12.5 \mathrm{~mm}$. A second specimen shows a maximum diameter of 11.3 $\mathrm{mm}$. at a point about $20 \mathrm{~mm}$. above the apex and then decreases to $10.5 \mathrm{~mm}$. at a distances of about $28 \mathrm{~mm}$. from the apex.

Neither specimen has the surface well preserved, but on the larger one the oblique septal lines are indicated in the apical portion. At first they are $1.5 \mathrm{~mm}$. apart, this distance increasing to nearly $2 \mathrm{~mm}$. shortly after. The obliquity of the septal lines, with reference to the axis of the sluell, is 55 degrees. 
Horizon and Locality: In the lower Yehli limestone of Lower Ordovician age, at Yeh-li, northern rim of Kaiping coal basin. (Y. C. Sun coll.).

\section{Suecoceras attenuatum Grabau (sp. nov.)}

Plate IV, Figs. 8, 9.

Like the preceding, this is known only from the siphuncle, which clearly shows it to be a more slender form, and one which never reaches the siphuncular diameter of the preceding species.

The siphuncle (in fig. 8) gradually increases in diameter from the initial point, reaching its maximum of $9 \mathrm{~mm}$. at a point distant about $20 \mathrm{~mm}$. from the apex. After that it decreases again, until at the uppermost preserved end, it is $7.5 \mathrm{~mm}$., this being about $40 \mathrm{~mm}$. from the apex. In another specimen, the greatest diameter is $9.3 \mathrm{~mm}$. at a point about $25 \mathrm{~mm}$. from the apex, narrowing subsequently to $8.9 \mathrm{~mm}$.

In one specimen, apparently of this species, the diameter of the siphuncle is 9.8 $\mathrm{mm}$. at the upper end, this being the aperture of the endosiphocone or uppermost one of the conical fillings (endosiphosheaths) of the siphuncle (see Plate IV fig. 9). The position of the endosiphosheaths in the siphuncle seems to be oblique, their axis not coinciding with the median line of the siphuncle as a whole.

Horizon and Locality: In the lower beds of the Yehli limestone near Yeh-li northern border of the Kaiping coal field, Chihli. (Y. C. Sun coll.).

\section{Genus VAGINOCERAS Hyatt \\ Vaginoceras tsinanense Grabau (sp. nov.) \\ Plate IV, Figs. 10a, b.}

Represented at present only by the siphuncle, which however has certain very definite characters from which some of the other characters of the shell can be deduced.

The form of the siphuncle is sub-cylindrical, increasing from $9.6 \mathrm{~mm}$. at the lower preserved end, to $10.8 \mathrm{~mm}$. at the upper, the distance being $40 \mathrm{~mm}$. This gives a rate of tapering of $1 \mathrm{~mm}$. in a length of $331 / 3 \mathrm{~mm}$. 
The siphuncle is filled solidly with the endosiphosheaths but these have been converted into crystalline lime. The upper portion of the specimen however shows the endosiphocone or funnel-like prolongation of the living-chamber into the siphuncle, bounded by the last endosiphosheath. This part of the specimen is partly filled with the lime matrix in which the shell is embedded. Endosiphuncle unknown.

The sides of the siphuncle are distinctly marked by the necks of the septa, and these show that the later ones extend heyond the upper edge of the preceding one, thus showing that the shell belongs to the genus Vaginoceras. The direction of the septal lines is strongly oblique, forming an angle of about $50^{\circ}$ with the axis of the siphuncle and meeting on the ventral side in an angle of about $70^{\circ}$. This indicates that the siphuncle is subventran in position. The septa average about $3.3 \mathrm{~mm}$. apart.

The subcylindrical character of this siphuncle is its most marked feature, and this together with the obliquity of the septal lines, and their relative closeness, serve to differentiate this species from others found in the Ordovician beds of China.* In the characters noted, our species is not unlike the early stages of Vaginoceras oppletum Ruedemann, from the Chazy beds of the Lake. Champlain region of the eastern United States, but there is no indication that the Chinese species ever reached the size of the adult American form.

Horizon and Locality: In the upper quarry beds of the Machiakou limestone, associated with Actinoceras, Lophospira etc., Cement quarry Tangshan. Survey expedition coll.

\section{Family PILOCERATIDAE Hyatt}

\section{Genus Piloceras Salter \\ Piloceras platyventrum Grabau (sp. nov.)}

Plate IV, Figs. 11 a-c, $12 x \cdot c$. Text figures 1 a-e.

Siphuncle with broadly subconical apex with endosiphuncular sear or slightly protruding endosiphuncle; enlarging rapidly until at a point $15 \mathrm{~mm}$. from the apex (in one specimen fig 11), it has reached a diameter of $24 \mathrm{~mm}$., after which it enlarges more gradually at the rate of about $15 \mathrm{~mm}$. in 10 of length, while later on it appears to be subeylindrical. The apical portion of the siphuncle (for about $35 \mathrm{~mm}$. in the only specimen showing this part) appears smooth, this part ending in a faint broad but

* Several spccies occur in the Ordovician rocks of south China. These will be described in a future number of 
unmistakable constriction, after which the expanding shell of the siphuncle becomes annulated. This suggests that the apical portion of the siphuncle was not enelosed by eameræ. The amuulations (shown well in specimen fig. 12) are oblique, forming on the side an angle of about $60^{\circ}$ with the axis of the siphuncle. They become fainter on the ventral side, meeting in a broadly rounded forward curve or saddle. About five of these annulations occur in the space of $20 \mathrm{~mm}$.

In transverse section, the siphuncle appears slightly broader than high, the ventral surface being somewhat flattened.

Interior of siphuncle with endosyphosheaths and crystalline lime-filling between them. 'Two or possibly more of these older endosheaths are indicated. The endocone formed ly the final (last-formed) sheath of the most mature individual seen (fig. 12e), is of subcircular section in the upper part, with the ventral surface slightly flattened. In the lower part, or at least in the earlier sheaths, this ventral surface becomes strongly flattened and the greater part of the endocone lies dorsad of the center (fig. 11e). It is continued posteriory in the dorso-ventrally compressed endosiphuncle. The thickness of the last endosheath (the wall of the endocone) is about equal to that of the wall of the siphuncle.

In the specimen shown in fig. 11, the dorso-ventral diameter is $31 \mathrm{~mm}$., the corresponding diameter of the endocone is $11.5 \mathrm{~mm}$., the space between it and the ventral surface being $11.5 \mathrm{~mm}$., while that between its dorsal surface and the corresponding surface of the siphuncle is $8 \mathrm{~mm}$. This point is about $13 \mathrm{~mm}$. from the apex of the endocone.

A series of sections of another specimen shows the following relationship. (Text figs. 1a-e).

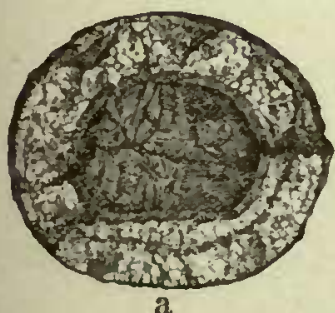

a
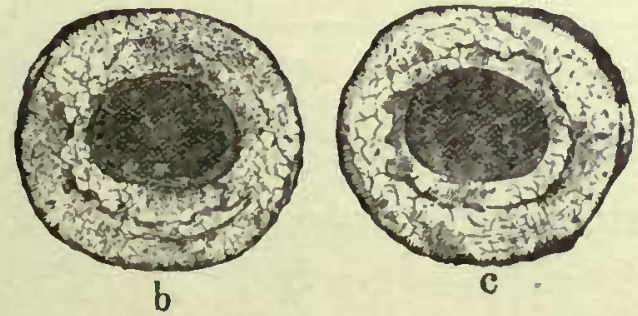
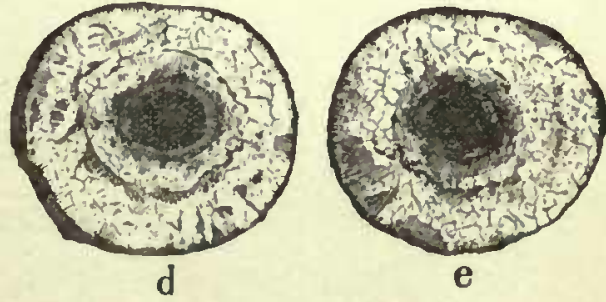

Figs 1 a-e. Succesire ernss sections of the siphuncle of Piloceras platyrentrum (For distances apart, and measurements see table p. 4t); 1a, largest section preserved; 1e, last section before end of endoeone. Natural size. 


\begin{tabular}{|c|c|c|c|c|c|c|}
\hline \multirow{2}{*}{$\begin{array}{l}\text { Section } \\
\text { No. }\end{array}$} & \multirow{2}{*}{$\begin{array}{c}\text { Distances between } \\
\text { Sections }\end{array}$} & \multicolumn{2}{|c|}{$\begin{array}{l}\text { Dorso-ventral } \\
\text { diameters }\end{array}$} & \multirow{2}{*}{$\begin{array}{c}\text { Distances } \\
\text { between } \\
\text { ventral } \\
\text { surfaces } \\
\text { of siphuncle } \\
\text { \& endocone }\end{array}$} & \multicolumn{2}{|c|}{ Lateral diameters } \\
\hline & & $\begin{array}{c}\text { of } \\
\text { Siphuncle }\end{array}$ & $\begin{array}{c}\text { of } \\
\text { Endocone }\end{array}$ & & $\begin{array}{c}\text { of } \\
\text { Siphuncle }\end{array}$ & $\begin{array}{c}\text { of } \\
\text { Endocone }\end{array}$ \\
\hline a & $15 \mathrm{~mm}$ & & $15.3 \mathrm{~mm}$. & & & \\
\hline b & $2 \mathrm{~mm}$. & $26.8 \quad$, & & & & $13.2 \quad$, \\
\hline $\mathrm{c}$ & $6 \mathrm{~mm}$. & & & & 29.5, & $12.3 \quad$, \\
\hline$d$ & $2 \mathrm{~mm}$. & & & & 28.5, & 8. " , \\
\hline e & $6 \mathrm{~mm}$. & 25.5 & $5.5 \quad$, & 11.3 & 28. ," & 7. \\
\hline f & & $23.7 \quad$, & - & - & 26. , , & - \\
\hline
\end{tabular}

In the specinen from which these sections are taken, the annulations of the shell of the siphuncle are finer, there being 5 in the space of $10 \mathrm{~mm}$. This specimen is recorded as from the lower horizon, the Peilintze limestone, whereas the others oceur in the upper or Liangehiashan limestone of the Shih-Mun-Chai district. The specimen in question may represent a distinct species.

Horizons and Locality: Two specimens of this species were obtained by Dr. F. F. Nathieu from the Liangchiashan limestone at Liang-Chia-Shan, Shih-Mun-Chai near Chingwangtao, eastern Chihli province. Another specimen with finer annulations and siphuncle less flattened ventrally, was obtained from the Chillioceras or Peilintze limestone of the same region (this may possibly be a case of mislabelling). The former horizon is the upper part of the Lower Ordovician.

\section{Family CHIHLIOCERATIDAE Grabau (fam. nov.)}

Genus Chihloceras Grabau (gen. nov.)

Text Figures 2-16

Breviconic orthoceracones with large and stout siphuncle, which is surrounded by a definite wall or siphuncular shell; with rounded apical end, the center of which is marked by a nuammillary elevation with a circular scar, representing the beginning of the endosiphuncle. Siphuncle filled with endosheaths and organically deposited mineral matter as in Piloceras. Endosheaths flattened ventrally, at least in the adult. In the final one, this flat face is produced anteriorly in the form of a blade-like prolongation, which is 
either flat or slightly arched inwards with depressed sides. In its general form and character the final endosheath suggests the eonotheea of the Belomnite which is prolonged forward into the delicate blade-like proöstracum, or the similar blade of the odern cuttle-fish. This blade-like prolongation slopes ventrad until it apparently joins the wall of the siphuncle on the ventral side. On the dorsal side, the blade may have been covered by the shell of the siphuncle, but of this there is no positive evidence. Indeed the sections negative it, although it is of course conceivable that the shell was broken away before burial.

The endocone is triple in character. In the genotype the main part has a sub. quadrangular to sub-crescentric cross-section, but appears to taper into a more or less flattened conical alveolus towards the apex. On the ventral side, where the wall of the endocone is prolonged into the blade, the inner surface is gently convex i. e. arehed upward

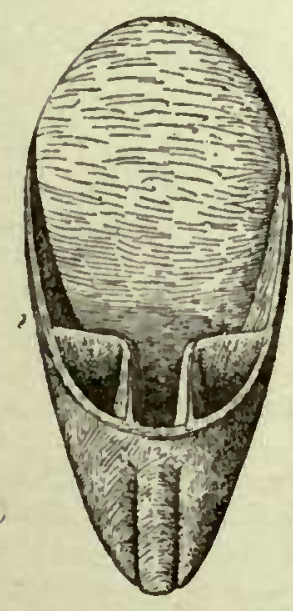

Fig. 4.

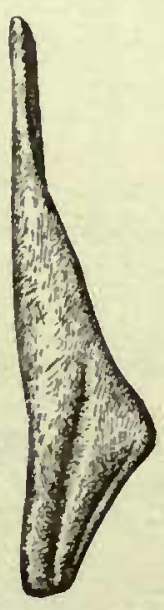

Fig. 5 .

Fig. 4. Chihlioceras nathani. Dorsal view of a model of the final endosheath, which forms the compound endocone of the siphuncle of this species. Two thirds natural size.

Fig. 5. Chihlioceras nathani. Side view of the model of the endocone shown in fig. 4. Two thirds uatural size.

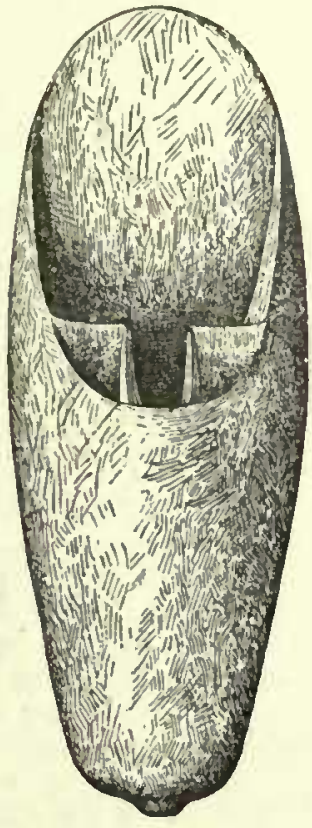

Fig. 2.

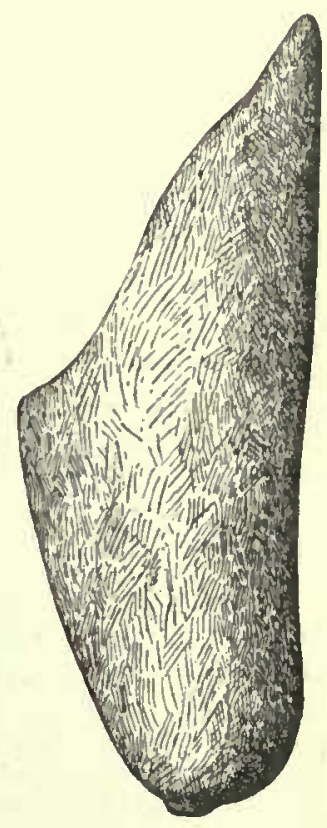

Fig. 3.
Fig. 2. Chihlioceras nathani, Dorsal view of a model of the siphuncle of this species with the compound endocone in place. Two thirds natural size.

Fig. 3. Chihlioceras nathani. Side view of the same. (The annulations of the surface are not represented.)

(dorsally) with the sides sharply depressed (see text fig. 7). The upper surface of this cavity is flat or nearly so, exeept for the median portion, which is prolonged dorsally into a broad noteh or emargination, on either side of which lie the dorso-lateral alveoli. The outer wall of these is rounded, but the inner wall consists of two limbs, approximately at right angles to each other, one, the dorsoventral limb, separating it from the median prolongation of the main eavity, the other being horizontal and dividing the lateral and main alveolar eavities (see text figs. 4 and 7 ). The position of this 
final endosheath is nearer the dorsal than the ventral side of the siphuncle (text fig. 6) as is shown by the two parallel sections (text figs. 8 and 9 ), taken essentially parallel

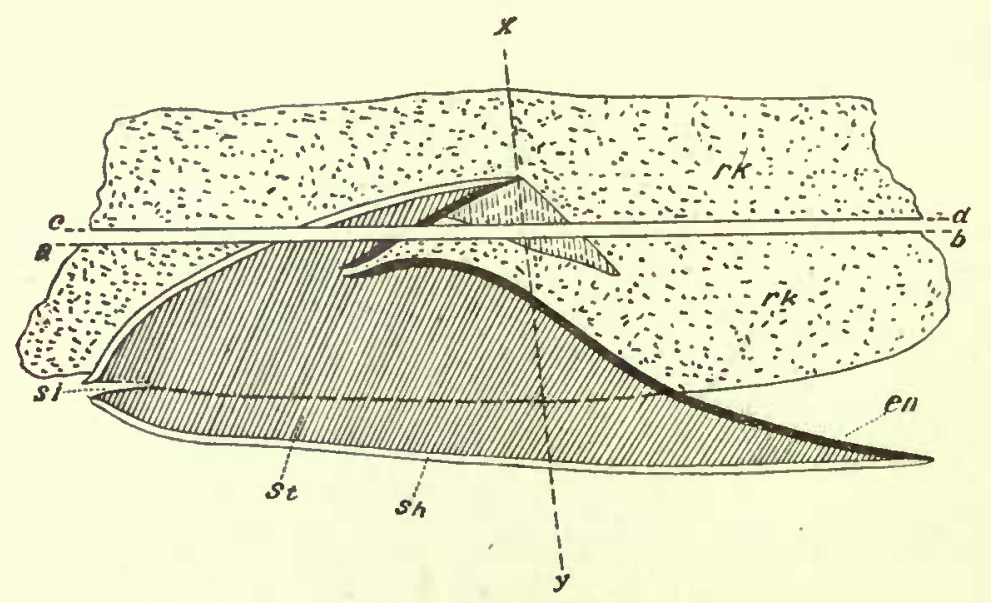

Fig. 6. Chihlioceras nathani. Restored longitudinal section, constructer from actual measurements along section $a-b$ and $c-d$, and tlie exposed worn surface of the ventral side (lower dotted line), and with the aid of other specimens. $x-y$ line of section shown in fig. 7. Two thirds natural size. en-final sheath, or endoconic lining; sh-ghcllwall of siphuncle (ectosiphuncle). st-stereoplasmic filling of siphuncle; si-endosiphotube; rk-section of rock matrix.

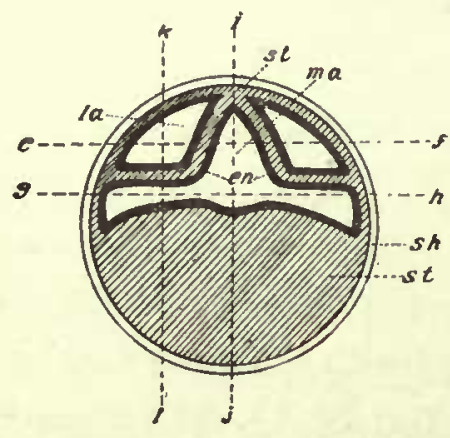

Fig. 7.

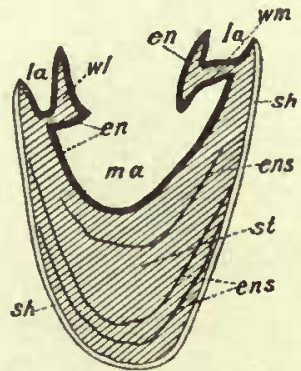

Fig. 8.

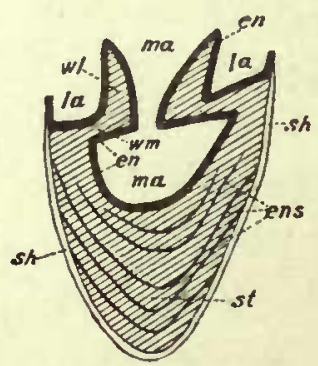

Fig. 9.

Fig. 7. Chihlioceras nathani. Transverse section along line $\mathbf{x}-\mathrm{y}$ of fig. $6 ; 2 / \hat{s}$ natural size. e - f. line of section of fig. $10 ; \mathrm{g}-\mathrm{h}$. line of section of fig. $11 ; \mathrm{i}-\mathrm{j}$. line of section of fig. $12 ; \mathrm{k}-1$. line of section of fig. 13 ; en-parts of endoconic lining or final sheath; la-lateral alveolus; ma-median alveolus; $s h$-shell of siphuncle (ectosiphuncle); $s t$-stereop'asmic filling.

Fig. 8. Chihlioceras nathani. Somewhat restored section along line $a-b$. fig. 6 . (For actual appearance of section see Plate II, fig. 11.) - 2/3 natural gize. The spetion is cut obliquely to the axis of the lateral alveoli (sce text fig. 2), and cuts the lateral walls $(w l)$ as well as the lower walls ( $u m$ ) of the lateral alveoli; ens-older endosheatlis buried in the filling of stereoplasm st. (Other notations as in figs. 6 and 7.) 2,3 natural size.

Fig. 9. Chihlioceras nathani. Corresponding restorerl section along the line $\mathrm{c}-\mathrm{d}$ in fig. 6 . This section is here reversed, so that the parts have the same orientation as in fig. 8 . Notation as in fig. 8 . 2/3 natural size (Sce Plate II, fig. 12).

to the ventral surface of the siphuncle, as indieated by the lines a-b and e-d in text fig. 6 , which is drawn to seale, and is two thirds natural size. The sections (text figs. 8 and 9) show that the walls of the alveolar cavities are infolded portions of the sheath, which, when considered separately i. e. as if freed from the enclosing organic lime-deposit, represents the aspect shown by the model, illustrated in text figs. 4 and 5. The walls, 
which separate the lateral from the main alveolar cavities, are thus double, with the addition of the crystalline, organically deposited lime (stereoplasm) between the two layers. This is diagrammatically represented in text figures 7 and 10 , which represent respectively transverse and longitudinal sections through these walls, (for location see text fig. 7), and can be recognized from an inspection of figs. 8 and 9 , which represent the actual oblique sections through both walls.

That an endosiphuncle extends from the base of the main alveolus to the apex of the siphuncle is suggested by the occurrence of the apical endosiphuncular scar seen on all the specimens, and is further suggested by the appearance of what seems to be a part of this tube in the natural section shown in fig. 13, Pl. IV, i. e. the specimen from sections of which the reconstruction of the sheath is mainly developed.

A consideration of the structure of the final endosheath

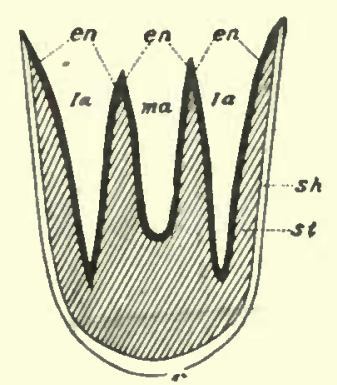

Fig. 10. Chihlioceras nathani. Diagrammatic longitudinal section along line $e-f$. in fig. 7 , parallel to axis of lateral alveoli. (Notation as in fig. 7.).

in the second species (C. chingwangtaoense (Plate II, figs. 13a, b.) shows very striking differences, but nevertheless a unity of plan. The main or median alveolar cavity has been much reduced, being subtriangular in outline, and only occupying the central

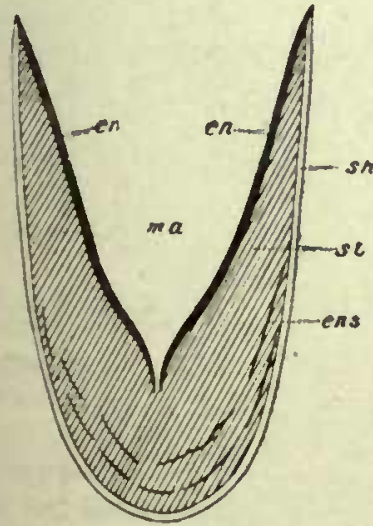

Fig. 11. Chihlioceras nathani. Diagrammatic longitudinal section through the broadest part of the median alveolus, along the line $g \cdot h$. in fig. 7. (Notation as in fig. 7.) third of the endosheath. The cavity too is short, though probably prolonged in the endosiphuncle. The dorso-lateral alveolar cavities are deep, and lenticular in section, the inner side being gently concave instead of rectangular. The partitions between the cavities are very thick, formed by the bent-over endosheath, with a thick filling of crystalline lime between. The crystalline filling (probably aragonite) has a radial structure where seen in section of the entire siphuncle. 'The outer wall of the dorso-lateral alveolar cavities was apparently formed liy the wall of the siphuncle. The sections (text figs. 14, 15 and 16) show this structure. The length of the two lateral alveoli may be quite different on opposite sides as shown in the specimen figured (Plate II, fig. 13a).

In none of the specimens so far obtained has a camerate portion been preserved. All the specimens are annulated, the annulations being essentially of the type seen on the siphuncle of Piloceras. This suggests a camerate structure but does not prove it. The annuli appear to be slightly oblique, converging forward on the ventral side. This suggests, that if camera were present they were mainly developed on the dorsal and lateral 
surfaces of the siphuncle, as would naturally be the case in a structure which, as these evidently did, rested upon the ventral surface. No specimen is however known with a complete ventral surface, and the convergence is only shown by a slight obliquity upon the sides.

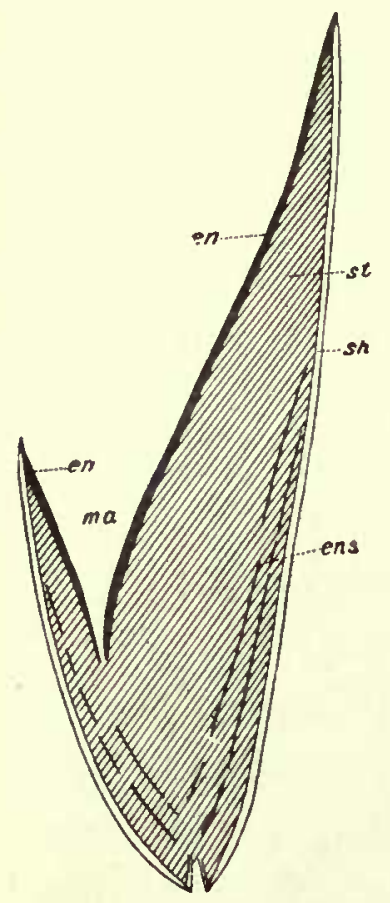

Flg. 12. Chihlioceras nathani. Diagrammatic Jongitudinal section in the median plane along the line $i-j$. in fig. 7 . (Notation as in fig. 7.)

As indicative of the position of the specimens, it may be noted that in one slab of rock, both sides of which were weathered, and in which four specimens of $C$. nathani were found, three, on the same side of the slab, exposed the dorsal side (Plate V.) (this was apparently the upper surface of the slab though sufficient care was not taken at the time of collecting to determine this) while the fourth, on the opposite side of the stratum (apparently the under side), exposed the weathered ventral surface (Plate IV fig. 13). This slab was cut apart, essentially parallel to the bedding plane, and the two cut surfaces show the sections of the dorsal portion of the lower specimen, these being shown in Plate II, figs. 11 and 12. The position of the longitudinal axis of the lower specimen was however approximately at right angles to that of the upper specimens.

The remarkable character of the siphuncle warrants the placing of this genus into a distinct family, that, of the Chinltoceratide. The characters of this new family may be summarized as follows:

Relatively short and stout holochoanitic othoceracones (and cyrtoceracones?) with large siphuncle, generally divided by endosheaths, and filled with organically deposited calcium carbonate. Final endosheath prolonged into a ventra] blade, and characterized by median and lateral endocones. Cameræ unknown, but if present, apparently as in Piloceras. Ordovician.

\section{Chihlioceras nathani Grabau (sp. nov.)}

Plate I fig. 10; Plate II, figs. 11, 12; Plate IV, fig. 13; Plate V; Text figures 2-13.

Siphuncle beginning with a regular rounded end, characterized by a subcentral mammillon with a large central scar, which marks the beginning of the endosiphuncle. The expansion is rapid so that in the space of about $16 \mathrm{~mm}$. from the apex (in the 
central specimen shown in Plate V) it has reached a diameter of $30 \mathrm{~mm}$. From this point the expansion is regular, until at about the point near the apex of the median endocone, about $40 \mathrm{~mm}$. farther (or $56 \mathrm{~mm}$. from the apex of the siphuncle) the lateral diameter is $40 \mathrm{~mm}$. This gives a rate of tapering of $1 \mathrm{~mm}$. in 4 . The earlier portion is regularly rounded, while the part occupied by the endocone is somewhat flattened on the ventral side. The endocone oceupies something more than one half the length of the shell, inelusive of the anterior blade. The apical portion in the center is rounded dorsally and flat or gently concave on the ventral side, its section thus being semi-eircular or compressed suboval, with the ventral side curved to a greater radius. Proceeding forward, the coneave central portion narrows and flattens, while the sides of the blade hecome strongly and sharply depressed, until near the anterior portion of the blade they form less than a right angle with the side. The aperture of the endocone, i. e. the edge formed by its meeting with the shell of the siphuncle, is oblique to the axis of the siphuncle, the most projecting portion being the center of the blade (see the restoration, text figs. 2 and 3 ). Lateral alveoli of the endocone shorter than the main cavity. In the specimen shown in the center of Plate $\mathrm{V}$ the alveoli are not seen, but in the somewhat crushed right hand specimen of that group, they are recognizable (Plate I fig. 10), being displaced somewhat to one side. The inner walls of these lateral alveoli form approximately a right angle, and consist of the reduplication of the endosheath with crystalline calcium carbonate filling between.

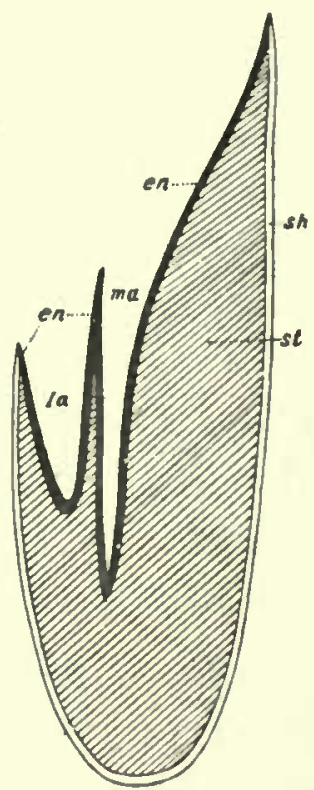

Fig. 13. Chihlioceras nathani. Diagrammatic longitudinal section half way between median plane and lateral markin, aloug line $k-l$. in fig, 7 , passing through lateral part of median, and one lateral alveolus (Notation as in fig. 7.) The outer wall of the lateral alveoli is convex and between it and the wall of the siphuncle, there is a thick layer of crystalline lime (organic deposit) which decreases wedge-like towards the rim of the endocone. (Text figure 10).

These lateral alveoli of the endocone hold a position above the base of the main endoconic eavity, so that there are distinct lateral chambers proceeding from this main median ehamber, and in position ventral to the lateral alveoli. This is elearly shown by the sections (Plate II figs. 11 and 12) and is represented in the model of the endosheath illustrated in text fig. 4. The endosheath itself (i. e. the wall of the endocone) has a thickness of half a millimeter or less, but beeause of the filling of erystalline lime between the reduplicated portions, which form the lateral and median alveoli, the thickness of the compound wall separating these alveoli may be from 2.5 to $6 \mathrm{~mm}$. (See the sections of these walls in figs. 11 and 12 Plate II). 
The older portion of the siphuncle is filled solidly with crystalline calcium carbonate, this occupying the entire space between the wall of the endocone (final endosheath), and probably its endo-siphuncular prolongation, and the wall or shell of the siphuncle. There are however indieations of one or more earlier endosheaths (See sections figs. 11 and 12 Plate II, and Plate V middle figure). The difference in the character of the outer zone of the solid portion of the siphuncle from that forming the inner portion, observable both in the worn specimen (Plate V, middle figure) and in the sections (Plate II figs. 11 and 12) suggest that at first the siphuncle was filled with closely set endosheaths (which in the large specimen of the group on Plate $V$ formed a thickness of about $7 \mathrm{~mm}$.), and then crystalline calcium carbonate (aragonite?) was deposited by the animal, without further formation of definite endosheaths, until the final one was formed by the adult animal. The appearance of these older endosheaths suggests their similarity to those of Piloceras, or to a primitive form from which both Chillioceras and Piloceras were derived.*

The wall or shell of the siphuncle is thin but continuous. It is annulated, though indistinetly so, near the apical portion, while forward, the anuulations become pronounced and regular. The annuli present a long gently convex forward slope and a shorter more abrupt, but still convex apical slope. There are 10 of these annuli in the space of $35 \mathrm{~mm}$., giving them an average width of $3.5 \mathrm{~mm}$. There is however a gradual increase in the width, the posterior ones being less than $3 \mathrm{~mm}$. wide. The depressions between the annuli are very shallow. While this is the character in the earlier portion of the siphunele, continuing for varying lengths in different specimens, it gradually changes in the later - formed portion, where the annuli become narrowly rounded, with broad gently concave interspaces. In the specimen shown in fig. $13 \mathrm{Pl}$. IV, this type of annulation begins about $30 \mathrm{~mm}$. from the apex, and there are 10 , annuli in the space of $38 \mathrm{~mm}$., these also inereasing slightly in width forward.

The annuli are oblique, bending forward on the ventral side. The angle which they form with the axis of the siphuncle on the side of the siphuncle, was found in one case to be about 30 degrees, but less than that in another specimen. Their ventral aspect is unknown.

Camere not known, none of the specimens showing any indications of them other than the annulations of the siphuncle. Though this annulation is suggestive of a camerate nature of the shell, it is not a positive indication, as camerate shells with

* In the locality from which these specimens were obtained, they are restricted to the lower division, while Piloceras occurs in the higher division, with one doubtful representation in the lower. 
obliquely annulated outer wall are found in higher Ordovician beds of this region. The general similarity of the annulations to those of the siphuncle of Piloceras may indicate, however, a similar camerated shell.

Horizon and Locality: This species has been found in the Peilintze limestone associated with Archicocyathus, Ophileta squamosa etc., in the Shih-Mun-Chai region near Chingwangtao, Lingyühsien district, Chihli province. Several specimens were collected by Dr. F. F. Mathieu of the Kailan Mining $\Lambda$ dministration. The horizon is Lower Ordovician. The specific name is given in honor of Mr. W. S. Nathan, president of the Failan Mining Administration, in appreciation of his keen interest in the development of Chinese geology, and his recognition of the important place which stratigraphic and palæontologic problems hold in the practical development of mining interests.

\section{Chihlioceras chingwangtaöense Grabau (sp. nov.)}

I'late II, Figs. 13a b. Text figures 14-16.

Sipluncle longer and more cylindrical than in the preceding species, tapering at the rate of $1 \mathrm{~mm}$. in 6 ; section subcircular. Interior filled with erystalline calcium carbonate, which has an indistinct radial structure. This occupies the space between the shell or wall of the siphuncle on the one hand, and the wall of the compound endocone (final endosheath) on the other. There are no indications of older sheaths, though these may occur in the apical portion which is unknown. Endosiphuncle apparently central, but the indications are faint. Wall of the endocone prolonged forward in a flat blade which slopes forward, forming an angle of 12 degrees with the dorsal surface of the siphuncle (See text fig. 14). If the rate of tapering is uniform, the length of the anterior blacle would approximate $110 \mathrm{~mm}$.

The blade is flat, except for a slight median longitudinal depression, most. marked in the alveolar portion. The lateral margins of the blade form a sharp angle with the sides of the siphuncle, and the wall or shell of the latter was evidently continued over at least the posterior part of the blade. Posteriorly the blade ends in the median alveolus, the base of which occupies one third of the width of the siphuncle. Its height is slightly less than the basal width, and its form is subtriangular but with curved sides. Its position is approximately in the center of the siphuncle or slightly above it. Its deptlı has not been ascertained, as some of the matrix which filled it, has not been removed. The partition between it and the laternl alveoli is thick, heing from 7 to $8 \mathrm{~mm}$. at the 
rounded forward end, and increasing in thickness apicad. (See section, text figures 15 and 16). It consists of the thin endoconic walls (reduplications of the endosheath) and the filling of crystalline calcium carbonate between these.

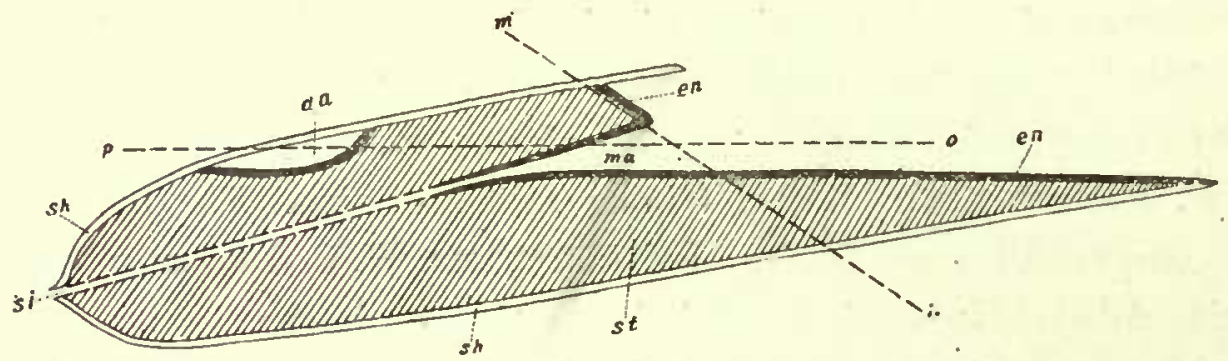

Fig. 14. Chihlioceras chingwangtaoense. Diagrammatic longitudinal section along the median dorso-ventral plane of a restored individual; $m$-n.-section line of fig. $15 ; 0$-p.-section line of fig. $16 ; s h$.-shell (ectosiphnncular wall); st. stereoplasmic filling; si.-endosiphotube; en.-endoconic lining or terminal endosheath; da.-dorsal alveolus; ma.-median alveolus.

The lateral alveoli are lenticular in section, only the inner, gently concave wall being formed by a part of the endosheath, while the outer is formed by the wall of the siphuncle, and in the type specimen, as preserved, is broken away. In this specimen the

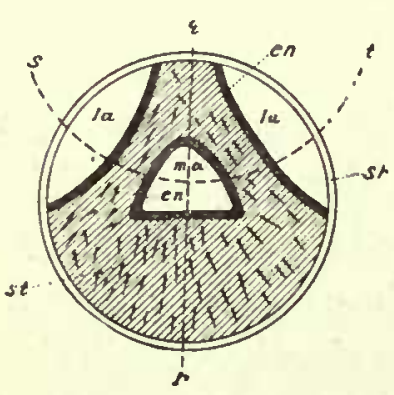

Fig. 15. Chihlioceras chingwengtaoense. Diagrammatie crosssection along line $m-n$. in fig. 14; $q-r$-median dorso-ventral plane (line of section of fig. 14); 8-t.-line of section of fig. 16; la.-lateral .alveoli; other notations as in fig. 14.

from the slopes of the lateral alveoli, this being indicated in the restored longitudinal section (text figure 14).

The inner shell or siphuncular wall, is about $0.3 \mathrm{~mm}$. in thickness and strongly and regularly annulated upon the sides, these annulations forming an angle of approximately $82^{\circ}$ with the dorsal surface, or $70^{\circ}$ with the plane of the anterior endoconic blade.

* The sliell is oriented with the apex to the observer, the aperture or anterior end pointing away, and the ventral side, (i.e. flattened side of endocone), downwards. The right and left sides then correspond to the ouserver's right and left hand. In the figures on Plate II the position is reversed, so as to show the structure more elearly; therefore the references must also be reversed from those here given. 
This indicates that on the ventral surface they formed a broad, low, forward arching curve or saddle, though the actual condition has not been observed. The annulations are broadly and regularly rounded and separated by concavities of equal form and width. There are six annulations in the space of $18 \mathrm{~mm}$. giving an average wirth, between the centers of adjoining concavities, of $3 \mathrm{~mm}$. Camere unknown, but their existence is apparently indicated by the annulations of the siphuncle.

Measurements: Diameter at aperture of alveoli $35 \mathrm{~mm}$. ; at point of confluence of lateral alveoli $28 \mathrm{~mm}$. Wilth of median alveolus at base $13.5 \mathrm{~mm}$; beight of same 10 nim.

Horizon and Locality: A single specimen of this speeies (Pl. II figs. 13 a-b) was obtained by Dr. F. F. Mathieu from the weathered, iron-stained Peilintze linıestone at Peilintze, associated with the preeding species and with Archacyathus

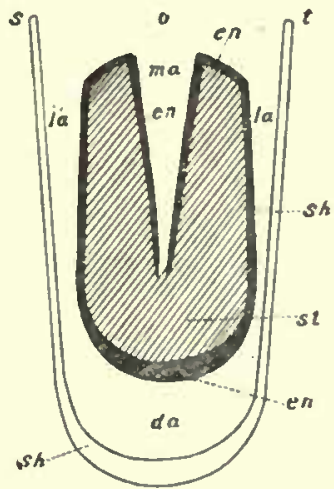

Fig. 16. Chihlinceres ching. wanglaoense. Diagrammatic section along line $a-p$. in fig. 11 and line $8-2$. in fig. 15 (notations as in figs. 14 aud 1 i). ete. The horizon is Lower Ordovieian.

\section{PHYLOGENE'IC SIGNIFICANCE OF THE SIPHUNCLE OF THE HOLOCHOANITES.}

It has long been known that in certain members of the suborder Holochonnites the early part of the siphuncle, so-called, is entirely devoid of surrounding eamer:e. The genus Proterocameroceras shows perhaps the most extensive pre-eamerate development of this part of the shell. This has been fully deseribed by Whiteaves and especially by Ruedemann, who in diseussing the siphunele of Proterocameroceras brainerdi from the Fort Cassin or upper Bceknantown (Lower Ordovician) of Lake Champlain (U. S. A.) spenks of the apieal portion as " projecting beyond the chambered shell for a distant of alout 75 mm., gradually expanding from the blunt apieal end, which here has a diameter of about $3 \mathrm{~mm}$, to $11.5 \mathrm{~mm}$. at the beginning of the phragmocone, where it contracts to $10 \mathrm{~nm}$. and then gradually expands agnin".*

* 1R. Ruedenuan - Ceplialoporla of the Beckmantown and Chazy formations of the Champlain Region. New York State IIuseum, Bulletin 90 p. 407, 1906. See also R. Ruedemann, Structure of some primitive Cephalopoda. Annual Report State Palcontologist N. Y. 1903, N. Y. State Nuseum Bull. 80 p. 296. I regret that I have not lian available, until after this paper was in type, this most searcling study of the structure of the primitive Ceplialopcha hy this eminent palreontologist, and that $\mathrm{my}$ reference conld, therefore, not be as extensive as was desirable. 
In Cameroceras on the other hand the nepionic bulb or swollen end of the siphuncle, is largely or wholly surrounded by camere, and this is also the case in Lndoceras, and generally in Vaginoceras except in such forms as Vaginoceras belemnitiforme Holm. These two genera differ from Cameroceras and Proterocameroceras in the absence of the siphuncular wall or shell, (the endosipholining of authors).

Another genus in which this preseptal cone or nepionic bulb exists before the camerate portion begins, is Nanno Clarke, also of Middle and early Upper Ordovician (Chazy and Black River) age. In this genus the siphuncle is strongly contracted at the beginning of the camerate portion, after which it remains in contact with the outer shell of the camerate portion, on the ventral side.

The presence of the siphonal wall or shell (endosipholining) in the more primitive genera is of marked significance. This wall is known to occur in Proterocamerocerus, Cameroceras, Nanno, Piloceras and Chillioceras, and perhaps in others. Where the shell begins with a non-camerate apical portion, i. e. with only the siphuncle, this siphuncular wall is the outer shell of the cephalopod hard structure. In other words the young cephalopod began shell-building with the "siphuncle" which consisted of the siphuncular shell-wall and the filling within it.

When we consider the length of this preseptal portion in Proterocameroceras (75 $\mathrm{mm}$. in $P$. brainerdi) it is evident, that the filling of the interior by endosheatlss and solid lime matter (stereoplasm), must have been carried on pari passu with the building of this shell, after the formation of a short initial hollow conical tube. For not only would such a long hollow tube be an element of extreme weakness, and therefore not likely to be preserved, but also, it is difficult to conceive that the cephalopod grew into such a long rod-like body, before it began the building of cameræ, and that this body soon thereafter began to shrink into the slender thread which occupied the endosiphuncle. But if the endosheaths and solid calcareous mattor were formed progressively as the tube grew in length, then it appears that these endosiphonal structures are more primitive shellfeatures than the cameræ. In other words, for a considerable period of its early history the cephalopod built only a slender shell, which it progressively filled with calcareous matter, marked at certain periods by resting stages, when the conical endosheath 1 sere built. If that is the case, the endosheaths have the same significance, in these primitive shelle, as the septa have in a shell of Orthoceras, and must be considered the homologues of these septa, whereupon the endosiphuncle becomes the homologue of the siphuncle of Orthoceras, and the shell of the "siphuncle" of the young Proterocameroceras the homologue of the shell of Orthoceras. That the endosheaths, or septa of the primitive Proterocameroceras are deeply conical, while those of Orthoceras are saucer-shaped, is only a detail 
of structure, which cannot effect the general question of homology. Again the filling with solid lime in the primitive shell of Proterocameroccras (and of the socalled siphuncle of the majority of the Holochoanites), while the outer septal spaces of Orthoceras are generally empty, is another detail, not relevant to the general question of homology. Indeed there is sometimes the beginning of such an organic deposit about the siphuncle of Orthoecras, while in Stereoplasmoccras and in Actinoceras this is the rule. In these genera too, a secondary septum terminates the deposit of organic lime, this supplementary septum or pseudoseptum being comparable to the sheaths of the "siphuncle" of the Holochoanites (see Plates VI - IX, and discussion on a subsequent page of this mernoir). Moreover such deposits are also found in certain Endoceratide such as laginoccras oppletum * where both erystalline lime and "pseudosepta" are formed. This, according to our interpretation, is a new feature, developed in the outer camere, and homaomorphic with, rather than homologous to the filling of the cameræ of Stereoplasmoceras and Actinoceras. It apparently represents a repetition of a structure which had its inception in the formation of the inner shell or "siphuncle" of the Holochoanites, and may perhaps indieate plyylogerontism in the group.

We may here consider briefly the subject of lime deposition by the mollusks, and its bearing upon the problem before us. On the basis of some experiments, and the consideration of others by Murray and Irvine, Steinmann (1889) concluded that the precipitation of calcium carbonate ly organisms was a purely chemical process, and was due to the formation of ammonia and carbon dioxide through the processes of decay which are constantly going on in the organism. These substances will precipitate ealcium carbonate from the sea water where it is present in the form of calcium sulphate ( $\left.\mathrm{Ca} \mathrm{SO}_{4}\right)$ and chloride $\left(\mathrm{Ca} \mathrm{Cl}_{2}\right)$. Because of the relatively small amount of lime salts which the animal takes into its body, Steinmann assumed that a part of the lime was directly derived from the surrounding medium. Such precipitation could of course take place only on the edge of the slsell if the mantle were free, and its shell-building surface in contact with the sea water. It has however been shown that this is not the case, at least not in those forms, chiefly fresh-water mollusks, which have so far been studied, for there the periostracum or outer horny covering, bends over the edge of the shell and joins the mantle-border by which it is indeed secreted. Thus lime deposition at the growing edge of the shell goes on entirely under cover of organic structures, and unless it can be shown that by some process of osmosis the sea water finds its way into the spaces between the mantle and the shell, direct precipitation of lime salts seems impossible. Physiologists 
generally appear to stand on the ground that all the lime of the mollusk shell is furnished by the animal, being derived from the food-supply (see especially Stempell 1900, and Biedermann 1901), but it must be recognized that their generalizations are based on the investigation of only a limited number of types. That marine mollusks derive all their lime from the food, seems highly questionable when we consider the vast amount of lime deposited by some of these organisms, especially sedentary types such as oysters, hippurites etc. The conclusion seems unavoidable, that in some way the animal appropriates lime from the sea water direct, or that in some manner the sea water gains access to the region where lime is deposited. If this is the case, we must allow that the calcium is precipitated as carbonate by the $\mathrm{C}_{2}$ produced by the animal itself, together with some other product to satisfy the $\mathrm{S}_{4}$ ion. For the sea water does not contain a sufficient quantity of $\mathrm{CO}_{3}$ ions ready to combine with the $\mathrm{Ca}$ ions and there is an excess of $\mathrm{S}_{4}$ ions which must be taken care of. Steinmann's hypothesis of the formation of ammonium carbonate, through normal decay of tissues, satisfies these requirements. The whole matter is a problem for the physiological chemist, and its solution must be left to him.

One thing, however, seems certain, namely that in different organisms there is a vast difference in the ability to deposit lime. Moreover in sedentary forms, lime deposition is far more active than in free moving types, being least in planktonic types. One need recall only the giant Tridacna shells of the Great Barrier reef, or the Hippurites of the Cretaceous. Furthermore, other classes of organisms, normally thin-shelled, bave sedentary members in which the shell is enormously and grotesquely distorted by excessive lime deposition. Such is Richthofenia among the brachiopods, an organism originally classed as a coral because of its remarkable form. Again, types such as the oyster, which are thin-shelled when very young (prodissoconch stage), become heavy-shelled by abundant lime deposition after attachment, while the related Pecten, which leads a freeswimming existence, only builds a relatively thin shell. Any one who has seen the ponderous oyster shells of the Tertiary, sometimes several inches thick, must agree that lime deposition here has passed beyond the normal stage required for the protection of the individual.

Of course it may be argued that the nature and abundance of lime-secreting cells, and their relative activity serves to determine the habitat of the organism. That, in other words, types with a tendency towards excessive lime formation will assume a sedentary life, and so give rise to genera and species normally of sedentary habit. In this connection it is noteworthy that many mollusks will build excessively heavy shells in old age, and from this it might be argued that types which in normal adulthood deposit 
much lime, belong to phylogerontic series. Why senile individuals and senile races (if such they are) should have their lime-secreting mantle cells over-stimulated so that they deposit an excess of lime, is not quite clear. Nor is it easy to understand why they should absorb more lime salts from the sca or from the food (if that is the sole source of the lime salts, which is very doubtful) in old age than in their younger stages, especially as there is often no corresponding increase in size of the shell-building mantle. If on the other hand, deposition of lime is more or less a purely chemical process, as Steinmann holds, and that its rate and amount of formation depends upon the rate of production of reagents which precipitate the salts, either from the normal secretion of the animal, or from sea water, which in some way (by osmosis?) has gained access to the regions of deposition, then we can understand that with increasing old age, or increasing senescenee of the race, increased decay of organic cells brings with it the increased production of ammonium carbonate, with the result that lime deposition also becomes augmenter.

The fact that lime is not deposited upon the periostracum, which both Stempell and Biedermann cite as ample refutation of Steinmann's theory, can in reality not be regarded as such, for the completed priostracum, though of conchyolin, has essentially the character of an inorganic body, and does not produce the necessary reagents.

I am not advocating the direct precipitation theory of Steinmann, but it appears to me that the pure secretion theory, which refers lime deposition in molluscan shells solcly to the epithelial cells of the mantle, or to special lime-secreting glands, meets with great difficulties when it is invoked for the explanation of excessive lime deposits, especially if all the lime salts are regarded as derived from the food of the animal and none from the sea water direct.

If in a cephalopod shell, the processes which make for lime deposition are most active at the growing edge of the mantle, the shell is rapidly elongated, while, by the rest of the mantle surface, only a thin nacreous shell-layer is formed. If the growth at the mantle edge is so rapid that the length of the shell eventually exceeds the stretching power of the animal, a periodic forward movement of the whole animal in the shell takes place, whereupon the continued separation of lime over the now free basal portion of the mantle-enclosed body, results in the formation of a septum. If the lime-separating processes are uniform all over the mantle surface of a cephalopod, (as they are in oysters among pelecypods), the basal part of a tubular or conical shell, such as an orthoceracone, will be filled solidly by successive layers of lime. These may have the form of consecutive endosheaths, or of crystalline lime with definite layers marking resting stages at intervals, $i$. e. of successive distant endosheaths with crystalline lime-filling or stereoplasm 
between. Thus viewed, the filling of the shell, whether with air-chamber-enclosing septa, with successive close-set endosheaths, or with solid lime, punctuated at intervals by endosheaths, is a matter of the relativity in the intensity of the lime-depositing ability, between the edge of the mantle and the entire surface.

Viewed in this light, the structure of the Holochoanites appears to be the natural result of a sedentary life-habit, or perhaps the tendency towards rapid lime deposition all over the mantle-surface, foreed the animal to assume a benthonic mode of life, which eventually must have been sedentary to all intents and purposes. That the Holochoanites, or the majority of them, led such a life on the bottom of the sea, is abundantly attested by their structure (especially the ventral flattening), and by their general morle of occurrence in the rocks (vide position of Chihlioceras as discussed on p. 48).

The building of cameræ in the Holochoanites must on this view be regarded as a newly acquired character, these structures being analogous to, but not homologous with, the camerre of the Orthpehoanites (Orthoceras etc). They must represent an expansion and reflexion of the mantle-edge, resulting in the addition of a new shell outside of the shell proper (the so-called siphuneular shell or wall, or the endosipholining), and we thus have the original shell enclosed by a secondary one, analogous to, but of course not strictly homologous with, the so-called shell of the Argonauta, the guard of belemnites, and the "apical cap" of Orthoceras truncatum. These new shells would thus form sub-annular structures of triangular, and later, more or less rhombic sections, like an automobile tire or a life preserver compressed into a triangular or rhombic section; but in most cases not extending entirely around the original shell, because this rested upon the bottom. The first of these veritable life-preservers, which probably aided the animal in keeping its oral end from sinking into the mud of the sea-bottom, formed the new shell by its outer or exposed side, and its first "camera", by its upper and inner side, which latter lay next to the original (inner) shell, and formed the so-called siphonal funnel of the camere.

This interpretation meets with the difficulty of conceiving the modus operandi of the building of such an outer, closed air chamber around the shell. Especially would it seem hard to explain the manner of building of the inner wall of this chamber, i. e. the so-called siphonal funnel of the camerre, that part next to the inner shell or endosipholining. This difficulty may perhaps be obviated by assuming that the animal built at first a sub-annular or semi-lunar trough around the margin of the shell, by a compound reflexed portion of the mantle-edge as shown in the following sketches (Figs. 17 and 18). Such a structure is entirely analogues to the lateral alveoli of the final endosheath of Chihlioceras. (Plate II, figs. 13 a, b., also text-figs. 4, 5, 7, 10, 13 pp. 45-49). The second outer trough, built in this manner, would then ciose the preceding one and convert it into an 
air-chamber, first by effecting the elongation of the outer part, that which forms the new shell built by the mantle edge, and then, by the subsequent withdrawal, for a space, of the base of the reflexed part of the mantle, effecting the building of the basal layer of lime, which is the so-called septum of the camerate portion of the Holochoanites.

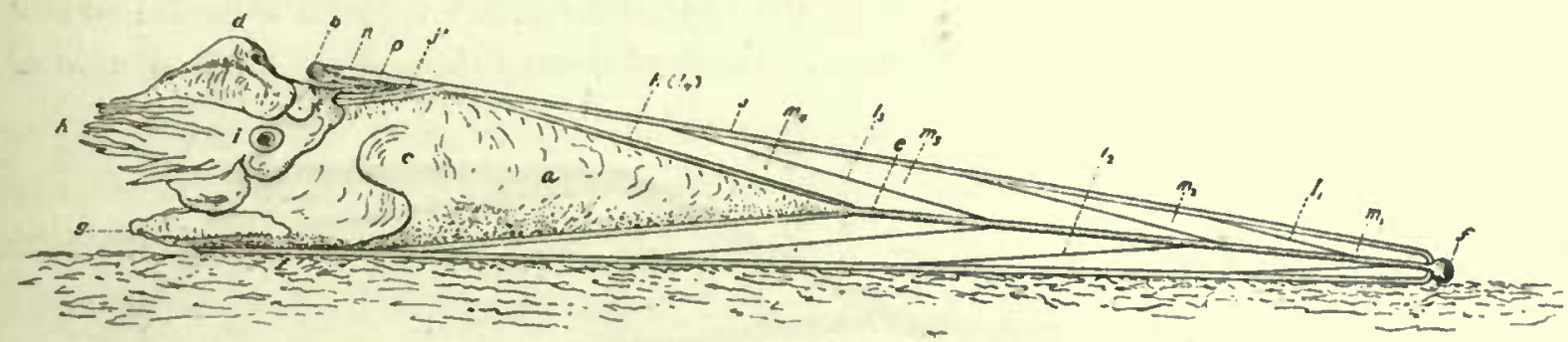

Fig. 17. Hypothetical restoration of a primitive lolochoanitic cephalopod, represented as resting with its ventral or hyponomie side upon the sea-floor, and with the shell sectioned. The stage here represented is at the beginning or the building of the camerse, previous to which it consisted only of the precamerate portion of the "sipliuncle". This is here represented in seetion with several conical endosheaths, the spaces between which are filled with solid stereoplasm, except the median tube or "endosipho-tube", which ends in the embryonic bulb, this being however non-calcareous and not preserved. The animal rests upon the final endosheath of the stage which surrounds the endocone of this period. The hypothesis of camera-building by a reflexed fold of the mantle, analogous to the dorsal fold of the mantle in Nautilus, is liere illustrated, the beginning of the first camera on the dorsal side being shown.

ANIMAL: $a$, mantle; $b$, marginal reflexed fold of the same, which is assumed to be functional in camera building; $c$, shell-muscle; $l$, hood; $e$, sipho, occupying the "endosipho-tube"; $f$, embryonic bulb, non calcareous (when calcifield it forms the protoconeh); $g$, hyponome; $h$, tentacles or arms; $i$, eye (left side). SHELL: $j$, ahell of early stage $i$. $e$. of preseptal part of "siphuncle", (ectosiphuncle of Ruedemann); $j$, continuation of came into camerate state at the contraetion of the "sjphuncle", forming the "endosipholining" of authors; $k$, last-formed endosheath at this atage, enclosing the "endocone" which is continued in the "endosipho-tube"; $l l-l 3$, earlier sheatlis (septa of primitive shell); $m 1-m 4$, "siphonal" chambers (camerse of primitive shell) filled solidly with stereoplasm; $n$, new shell or ahell of camerate portion; $a$, shell-lining of first eamera, deposited next to the continuation of the "old shell" (i. e. the continuation of shell of "siphuncle", the co-called endosipholining) and forming on the liypothesis here suggested the "siphonal funnel" or "neck" of the first "scptum" which has not jet been built.

I am perfectly well aware that this interpretation meets with a grave objection because of the fact that in Endoceras, Vaginoceras etc., the septal portion of the camerre is continued downwards in the siphonal neck, not upwards as such a mode of construction would require. But it must be remembered that in these forms, the septal necks take the place of the inner shell or the endosipholining, which is absent in these genera. Whitfield has recorded the observation, that the septal necks of Vaginoceras are continuous with the sheaths of the siphunele though Ruedemann holds that this needs verification. If it is correct, then the septa merely mark the rapid outward expansion of the mantle above the edge of the endosheath (which is really the upper edge of the siphonal neck) there being no further need for a reflex of the mantle on the suppression of the inner shell.

That such a reflexing of the mantle has occurred in some of these ancient cephalopods, is shown by the structure of Oithoceras truncatum Barrande, from the Ordovician and Silurian rocks of Bohemia and England. In this form the earlier camere 
are frequently dropped off or destroyed, whether ly accident or design, remains undetermined. The truncated end of the shell is then covered over ly a new deposit of calcareous material of distinctive form and design. 'This " apical cap" or calotte conique, is evidently formed by the animal, and for its formation a reflexed shell-secreting portion of the body is necessary. Barrande supposed that the animal possessed long palmate brachial appendages more or less analogous to those of Argonauta. These were capable of

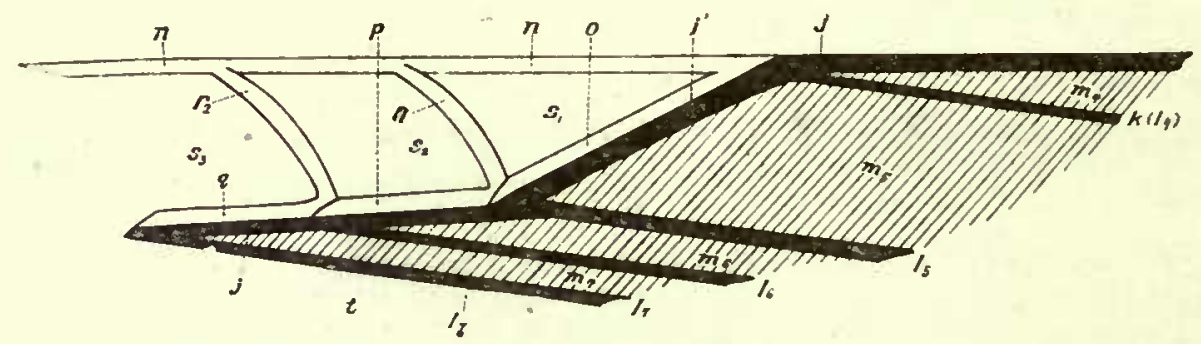

Fiy. 18. Diagram to illustrate the dorsal portion_of the early camerate part of the slell of a lolochoanitie nantiloid cephalopod. (See fig. 17). $j$, "old" shell or shell of "siphunele". $j$, $j$, continuation of same into eamerate portion forming the endosinholining; 44 , endosheath which at the stage represpnted by fig. 17 was the last one formed enclosing the endocone, $(k$. fig. 17$) ; 15, l b, l 7$, endosheaths since formed, 17 representing rle last-formed one at this stage, and enclosing the endocone of this stage; $m \neq$ to $m 7$, intersheath spaces filled with stereoplasm; $n$, and $o$, as in fig $17 ; p$, $q$, inuer shell-lining of canterx, forming the septal necks or fumels; r1, r2, septa of camerate portion; (o. forms septal neek of $r 1 ; p$, of $r 2 ; q$, of $r 3$ which has not yet been formed); $81,82,83$, first second and third eamera the last still open in front, and forming with the endocone $t$, a part of the living chamber.

reaching the basal portion of the shell, and having the power of secreting lime, they repaired the broken apex, reproducing the characters of the shell. Hyatt, on the other hand, considered that this outer shell-secreting organ was homologous with the fold of the mantle in Nautilus "This" be says, "is an active shell-secreting organ, which was certainly present, and also functionally active, in the Ammonites and Nautiloids, and probably more important in these ancient forms than it is now in the modern Nautilus. This is also more consistent with the structure of the Belemnoid, which, as is easily seen in the famons example of the preserved animal, had no sich pair of enlarged arms and yet deposited exteriorly, a solid covering, the guard, which is in our opinion the homologue of the solid filling of the truncated end of Orthoceras." *

A similar organically deposited layer of lime covers the initial end of Vaginocerns belemnitiforme Holm, before the commeneement of the outer cameræ.

It has been frequently noted, that when the outer camere begin building, the diameter of the inner shell or "siphuncle" is more or less abruptly contracted. 'This is found in Cameroceras in Nanno and in Vaginoceras belemnitiforme. This can be accounted for by the alsupt elongation of the animal's body necessary at this stage, if the animal 
forms a reflex fold of a part of its mantle, that which builds the initial outer "collar", which eventually becomes the first outer camera.

Whether this suggestion regarding the mode of building of this outer series of camere will be shown by future discoveries to be correct or not, I believe that the very existence of the initial precamerate stage of the "siphuncle" with its own shell-wall and with conical, septa-like sheaths, prolonged into an endo-siphuncle, indicates that it is a primitive shell-type which was complete in itself, and that the development of outer camere at a later stage adds a new feature to the shell as a whole. The continuance of the "siphuncular wall" or the shell of this primitive non-camerate organism, into the camerate portion in primitive forms, further emplasizes the independence of this inner structure. The homology of this inner shell with the shell of Orthoceras, and of the sheaths with the septa of Orthoceras, would therefore seem to admit of little doubt. Moreover, as we have learned to take ontogeny as an infallible guide to phylogeny, if rightly applied, we are forced to conclude that the most primitive Holochoanites were without the outer camerate portion, thus representing in their adult stages, the condition seen in the young of Proterncameroceras, Nanno and others of this type of structure. That the existence of such has not been absolutely determined, signifies little, for our knowledge of the earliest cephalopod faunas is still very meager. As noted in the description of Chillioceras, it is possible that that genus was non-camerate, the annulations being merely surface "ornamentations" such as are found in the shells of many later ceplalopods. Certainly there is no indication whatever in these shells, of the presence of camerse, such as in found in other annulated "siphuncles" in our rocks, where portions of the "septal necks" still adhere to the shell of the "siphuncle", though there is no other trace of the cameræ. Furthermore the remarkable form of Chillioceras, its oblique aperture, and the long anterior ventral blade, are hardly consistent with the idea of the former presence of camere. Possibly the same holds true of the rapidly expanding "siphuncles" of Pilocerus platyventrum Grabau, of our rocks (Plate IV figs. 11 and 12), for although some specimens are annulated, these annulations show no trace of adhesion of "septal necks", while the apical portion shown in Plate IV fig. 11 is entirely without such amulations. It seems at least likely that this species too began with a nor-camerate portion, and if camere were added, this took place only in the later stages, when the "sipluuncle" had become cylindrical.

If we now enquire into the genetic rela tionships between the Holochoanites and the Orthochoanites, it would seem to be evident, that they can only represent divergent branches from a common ancestral stock. I have elsewhere suggested $*$ that this 
ancestral stock is represented by the sub-order, Protochoanites Grabau and Shimer, to which we have referred the only known Cambrian cephalopod Volborthella. This genus has been defined as a small orthoceracone with conical-shaped septa, pierced by a simple hole in the apex, though the presence of such a siphuncular hole has been questioned. Whether or not it occurs is of secondary importance as it appears that in some of the Holochoanites the "endo-siphuncle" is not present in the earliest part. But whether the known Cambrian protochoanite is the direct ancestor of both Orthcceras and the Holochoanites is of little moment. Certain it seems that shells so distinctive must represent divergent evolutional lines, one the orthochoanite branch becoming successful by the assumption of the chambered type of shell, the other, the holochoanite type disappearing with the close of the Ordovician, because its heavily weighted shell made active migration impossible in spite of the secondarily adopted device of outer camere. The extinction of the various genera of this group is in general coincident with great changes in physical geography, notably the extensive withdrawal of the seas at the end of the Palreo-Ordovician, and again at the end of Neo-Ordovician time, when practically the laist members of the group perished. Nor is it an unwarranted assumption that the excessive development of the sedentary habit may have affected the reproductive powers of these animals in one way or another, so that extinction may be in part due to this cause.

We would then interpret the phylogeny of the early cephalopods in the following manner:

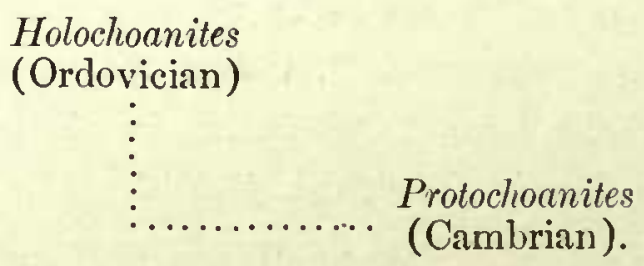

(to Trias.)

Orthochoanites

(Ordovician)

The Cyrtochoonites, represented in our rocks by Stereoplasmoceras, Actinoceras, Cyrtactinoceras, and Gonioceras, may have been derived from primitive Orthochoanites, or they may represent an independent line of evolution from the ancestral stock. The discovery of the genus Stereoplasmoctias, with characters intermediate between Orthoceras and Actinoceras, makes the former view the more likely one.

We may here briefly refer to the remarkable early Ordovician cephalopod Diphragmoceras Hyatt. This has the "siphuncle:" divided by tabuli alternating witl the septa of the camerate outer shell. Both the camerx and the chambers of the siphuncle are empty. This genus has sometimes been referred to as representing a transition from the Holochoanites (Endoceran type) to the Orthochoanites (Orthoceran 
type), but it is difficult to see how it can be so regarded. It represents really an Endoceran type in which the sheaths have assumed the form of tabulic separated by interspaces, and as such rather supports the explanation of the relationship between the endosheaths of Holochoanites and the septa of Orthochoanites given above. Thus it is a case of parallel development to Orthoceras, or the assumption, by the inner or true shell in a holochoanitic type, of the orthoceran character. Unless we assume that the outer shell is suppressed in the development of the Orthoceran type, we cannot regard this form as in any way showing ancestral characters. Moreover, if such were the origin of Orthoceras, the close genetic relation of the endosheaths of the one to the septa of the other type, would be demonstrated.

\section{Suborder Orthochoanites Hyatt \\ Family CYCLOCERATID $A$ E Hyatt}

Genus CyCloceras McCoy

\section{Cycloceras (?) peitoutzense Grabau (sp. nov.)}

Plate VI, figs, 1-4

A number of fragments of an annulated orthocerncone have been oltained from the upper beds of the Actinoceras limestone a short distance west of Chaokouchuang. Although they belong to different individuals and show considerable variation in size, they are nevertheless regarded as representing a single species. As this is the only annulated orthoceracone known from north China, it will be deseribed despite the imperfect claracter of the material.

The smallest shell fragment (PI. VI, fig. 1) is about $30 \mathrm{~mm}$. long, the diameter ranging from $5.3 \mathrm{~mm}$. at the lower (partly concealed) end, to $7.2 \mathrm{~mm}$. at the upper end. Eight annulations are shown in a distance which is $23 \mathrm{~mm}$. from the center of the first to the center of the eighth annulation. The annulations appear to be straight, encireling the shell without deflection, rounded, but separated by broad, strongly concave interspaces which gradually increase in length with the growth of the shell. Very faint longitudinal lines are visible upon the early portion of this fragment, but the gieater part seems destitute of them. Siphuncle somewhat excentric, its diameter at the upper end of the fragment being $1.25 \mathrm{~mm}$. Sutures and septa not visible.

A second fragment (Plate VI, fig. 2) shows 7 annulations the distance between the centers of the first and seventh being $26 \mathrm{~mm}$. 'The diameter of the shell at the upper end is $12.2 \mathrm{~mm}$. 
This fragment too shows no longitudinal lines, but in some of the interspaces occur very faint indications of concentric lines. The specimen appears to represent the. filling of the living chamber, as a longitudinal section shows a total absence of septa.

A still larger specimen, which is a partly crushed and incompletely exposed shell, has a diameter of about $13.5 \mathrm{~mm}$. and is characterized by abrupt annulations, the centers of which range from 4.5 to $4.8 \mathrm{~mm}$. apart. The annulations themselves have a thickness of about $1 \mathrm{~mm}$.; the summit is rounded, and the interspaces are very nearly flat in some parts, though they show a concavity in others. No longitudinal sculpture is shown, but there is again a faint indication of fine concentric lines in the interspaces.

Only a few septa are indicated, their position corresponding apparently to the annulations. Their concavity is about equal to half the distance between the anuulations. Siphuncle slightly excentric, large, its diameter being about $2.5 \mathrm{~mm}$. where the diameter of the shell is about $13.5 \mathrm{~mm}$.

Another specimen of this type (Plate VI, fig. 3) has the annulations slightly oblique, but sharply elevated, compressed and separated by deep flat interspaces. The distance between five annulations (including 4 interspaces) is $24 \mathrm{~mm}$. the width of the annulations being a little over $1 \mathrm{~mm}$. at the base but only about half that at the top. The diameter of this fragment is approximately $14 \mathrm{~mm}$. and it appears to be slightly curved.

A still larger fragment apparently a part of the same individual as the preceding (Plate VI, fig. 3) shows annulations $8.5 \mathrm{~mm}$. apart, their thickness being nearly $2 \mathrm{~mm}$. at the luase, and their height alout the same. This specimen shows fine sharp concentric strix somewhat narrower than the interspaces between them, covering the entire shell, including the annulations (Plate VI, fig. 4). There are about five of these strix in 1 $\mathrm{mm}$. The diameter of this fragment was probably between 18 and $20 \mathrm{~mm}$. Siphuncle unknown.

The last three specimens described differ rather strongly from the fragments illustrated in figs. 1 and 2 of Plate VI especially in their narrow compressed and high annulations, and the very broad and nearly flat interspaces. It is quite possible that two species are represented, but the material is too incomplete to warrant such a separation, especially as the internal characters are not ascertainable.

The generic position of this shell is in doubt. The entire absence of longitudinal sculpture except in the very young stages, would suggest that it belongs to the genus Protocycloceras of Hyatt. The faintness of the longitudinal sculpture on the young, however, together with the pronounced character of the annulations, and further the 
general weathered charaeter of the surface, suggests the possibility that if more perfect material were obtained, the longitudinal sculpture would be found to persist into the later stages as discontinuous ridges in the interspaces. In that ease the shell would he referalle to the genus Cycloceras. One might also argue, from the fact, that these fossils are associated with Actinoceras, and other late Middle and carly Upper Ordovician fossils, that they belong more likely to Cycloceras, rather than to Protocycloceras, which is most distinctive of the Lower Ordovician. Nor does the siphuncle help in the proper determination of the generic position of the form, as it is at present known only in section o: on the septal surface. 'The presence, in the largest fragment, of fine sharp concentrie strix, without indications of longitudinal striæ, however, makes reference to Cycloceras doulutful. Indeed this feature rather suggests Daw'sonoceras, but the concentric striæ are regular, instead of being the frilled edges of the growth-lines as in that genus. Such a surface character has not been recognized in other Ordovician eephalopods, and it is possible that we are dealing here with a new genus. However, as the material is too incomplete, and as too little can be ascertained of the septa and the character of the siphuncle, it seems best for the present to place the specimens in the genus Cycloceras, especially as in species of that genus the longitudinal seulpture is not always preserved.

Honizon and Localitirs: In the upper beds of the Actinoceras or Machiakou limestone, in Limekiln Ravine, near Pei-tou-tze N.W. of Chaokouchuang, Kaiping hasin, Chihli. (Coll. Geo. B. Barbour) also in the same formation in other outerops near Chaokonchuang and Pei-ton-tze. (Collected by the Survey expedition).

\section{Suborder Cyrtochoanites Hyatt Family LOXOCERATIDAE Hyatt}

Genus STEReoplasmoceras Grabatı (gen. nov.)

Non-annulated, regularly expanding orthoceracones with nummuloidal siphuncle, the nummuli more or less irregular and extending from septum to septum, widest near the centers of the cameræ, but without secondary annular deposits, or if these are present, they are irregular. Septa generally compound, or eomplicated by pseudosepta which extend only partway across the phragmocone, and join the preceding or succeeding septum. The space thus enclosed by the pseudosepta is commonly filled with crystalline stereoplasm deposited by the animal, this being present in varying amount, sometimes filling the whole or nearly the whole camera, especially in the older (earlier) parts of the phragmocone. 
This genus is closely related to Loxoceras, McCoy, with which it agrees in the character of the siphuncle. Its distinctive character however is seen in the development of the compound septa, or septa and pseudosepta, with stereoplasmic deposit between. In these respects the genus is related to Actinoceras. Indeed this genus may be considered as intermediate between Loxoceras, and Actinoceras, partaking of some characters peculiar to the one and of others characteristic of the other.

The exterior of the shell is unknown except that it is not annulated. So far as can be ascertained, the surface is smooth. Expansion is regular, and although the living chamber is still unknown, there is no reason for assuming that it is other than in Orthoceras.

Genotype. Stcreoplasmoceras pseudoseptatum Grabau, Ordovician.

It is highly probably that the specimen figured by Crick as Orthoceras or Actinoccras (Geol. Mag. New Ser. Dec. IV. Vol. X, Pl. XXII fig. A) belongs to this genus, for as far as can be ascertained from the reproduction of the photograph it shows the pseudosepta and stereoplasmic filling of $S$. pseudoseptatum.

\section{Stereoplasmoceras pseudoseptatum Grabaı (sp. nov.)}

Plate VI, figs. 5-7. Plate IX, fig. 11.

Shell regularly tapering, apparently at a variable rate, though this may be due to the variation in direction in which the sections are cut. In a specimen from Lincheng, Shantung (cat. no. 80) the rate of tapering appears to be 1 in 6.5 while in a sectioned specimen from Ningyang Shantung (Plate VI, fig. 6 cat. no. 57) it is only 1 in 12.5. Still another section of an typical specimen from Tangshan (Plate VI, fig. 5, cat no. 58) shows a rate of tapering of $1: 9.75$. These variations are probably due to the fact that the sections are cut somewhat obliquely and so do not give the true rate of tapering. The true rate lies probably between the two extremes - i.e. about 1:9.

Section subcircular, apparently a little flattened on one side. Septal distance about $4.6 \mathrm{~mm}$. (varying in the different specimens from 4.5 (rarely 4 ) to 4.7 , the shell diameter varying from $25-30 \mathrm{~mm}$. but not in the same proportion). Towards the apertural end in the longer specimens, the interval increases to $5 \mathrm{~mm}$. or to a little more, the maximum shell diameter observed being somewhat less than $40 \mathrm{~mm}$. The depth of the septa is from $1 \frac{1}{2}$ to $1 \frac{3}{4}$ camera. The septa are conspicuously compound, owing to the numerous pseudoseptr. On the upper side of the septum, the pseudosepta extend about 
one third the diameter of the shell towards the center. At first they are more or less parallel to the septum, then slope more or less abruptly to the septal surface near the center where they either join the septum, becoming confluent with it, or continue as an independent layer in contact with the septum at the center. At the shell margin these pseudosepta again join the main septum. The pseudosepta on the under side of the true septa are more irregular. As seen in section, some are annular, joining the main septum in the center as do the pseudosepta above. In other cases the pseudosepta diverge from the main septum some distance in from the shell-margin, and eontinue across the center to within a similar distance of the opposite shell-margin. These pseudosepta thus have a greater curvature than that of the true septa. When the pseudoseptum is confined to the marginal portion of the section, it is in close contact, for a space, with the psendoseptum which joins the next preceding septum on the upper side. Again, the pseudoseptum on the under side may become irregular, as it approaches the center, being abruptly bent down, before it bends up again to join the under side of the septum above it. The space between the pseudosepta and the septum to which they belong both above and below this true septum, is filled solidly with stereoplasm in the form of crystalline calcium carbonate (probably aragonite, at least originally). Thus in general the septa appear thickened on both upper and lower marginal portions by nearly equal amounts of stereoplasm, while the center is free from such thickening, the camere being filled only ly the lime-mud in which the shell was buried. In the older parts, where the lower pseudosepta seem to extend across the center (possibly due to the position of the section) nearly the whole of the camere appears filled with the stereoplasm.

The siphuncle is excentric, situated alout half-way between the center and the margin of the slightly flattened side, or a little nearer to the latter. Around it the camere are often free from stereoplasm for some considerable space. The siphuncle is nummuloidal, expanding to $7 \mathrm{~mm}$. in the center, where the septal distance is $4 \mathrm{~mm}$. but it does not appear to be regular. At the septa it contracts to about $2.5 \mathrm{~mm}$. There are either no stereoplasmic deposits, or, when present, they are irregular, and have the nature of a norrower tube within the more expanded outer nummulus. Characters of exterior of shell and of living chamber unknown.

A section of a specimen of Stereoplasmoceras from the Machiakou limestone of Wên-nan, Shantung (Plate IX fig. 11), appears to belong to this species, representing the earlier portion of the conch. The shell tapers at the rate of 1 in 6 . The siphuncle, though appearing centran in the section, is only about $4 \mathrm{~mm}$. from the ventral margin at the lower end of the specimen, and $5.5 \mathrm{~mm}$. at the upper end. The diameter of the nummuli is $7 \mathrm{~mm}$. where the shell section is $28 \mathrm{~mm}$. wide, in the upper end of the 
section, and $5 \mathrm{~mm}$., where the section is $18 \mathrm{~mm}$. wide. The septal interval ranges from about $3.8 \mathrm{~mm}$. in the lower, to $4 \mathrm{~mm}$. in the upper part. The concavity of the septa is equal to nearly 2 camera lengths. In the median portion of the specimen, the nummuli show a distinct narrow central tube, which extends from septum to septum. Around these septal necks, there is an irregular deposit of stereoplasm which partly fills the nummuli, the remainder being filled by crystalline calcite of secondary origin. The central tukes or septal necks, stop abruptly at a septum about one-third the length of the fragment from the bottom, this abrupt cessation suggesting that they are not present in the earlier nummuli, which contain only an irregular deposit of stereoplasm. The pseudosepta are of the type deseribed for the larger specimens of this species.

Horizon and Localities: So far as known, this species is confined to the Machiakou limestone where it is associated with Actinoceras. Characteristic specimens have been obtained from Lincheng in Shantung (F. F. Mathieu), from Ningyang, Shantung, and Tangshan and Lushan, Chihli, (Survey collection), from Wên-nan, Mon-Yin-Hsien Shantung (V. K. Ting coll.) and from Chaokouchuang, Chihli (Survey expedition of 1921). It is thus seen to be a widespread species.

\section{Stereoplasmoceras machiakounense Grabau (sp. nov.)}

Plate VI, Figs. 8

Shell subcylindrical, tapering very gently, section apparently circular, siphuncle subcentran.

Septa moderately concave, the depth equal to about one camera. Septal distance varying from $4 \mathrm{~mm}$. in the lower part of the fragment, to $6 \mathrm{~mm}$. in the upper, the diameter of the shell being about 20 and $21 \mathrm{~mm}$. respectively. Pseudosepta irregularly developed, occurring in one part of a chamber but absent in another. Some cameræ are without pseudosepta, and are solidly filled with stereoplasm. In other cases, the camera on one side of the section is without stereoplasm, while on the other side, where a pseudoseptum is present, it may be partly filled by this deposit. So far as can be ascertained the stereoplasm is confined to the upper surface of the septum.

Siphuncle gently nummuloidal the nummuli swelling to a diameter of $5.3 \mathrm{~mm}$. in the center, and contracting to $3 \mathrm{~mm}$. at the septal ends. There is no stereoplasm in the siphuncle which is filled only with the matrix. 
Another specimen from Lincheng Shantung, referred to this species, lias a septal distance of $7 \mathrm{~mm}$. where the shell is $21 \mathrm{~mm}$. in diameter. The rate of tapering of this specimen, as indicated in the section, is 1 in 8.5 . There is comparatively little stereoplasm in the cameræ, and it appears to be confined to the upper surface of the septum and bounded above by a pseudoseptum. The siphuncle is not shown in this specimen.

This species differs from $S$. pseudoseptatum in its proportionately more distant and somewhat shallower septa, in the narrowly nummuloidal siphuncle, the comparatively few pseudosepta and the frequent complete filling of the camerre with stereoplasm.

Horizon and Localities: In the Machiakou limestone at Machiakou Chihli province, (H. C. I'an, cat. no. 15, ) and in the same horizon at Lincheng, Shantung province (F. F. Mathieu, cat. no. 79). In both places the species is associated witl Actinoceras richthofeni, A tani etc. and is of early Upper Ordovician age. A specimen referred with some hesitation to this species, because of its narrower septal interval (4 where the diameter is $14 \mathrm{~mm} ., 4.5$ where it is $18 \mathrm{~mm}$.) came from Tse-yan, Ning-yang Hsien, Shantung. It has the same rate of tapering, and slight amount of stereoplasm found in the Lincheng specimen. (Survey collection cat. no. 82).

\section{Stereoplasmoceras actinoceriforme Grabau (sp. nov.)}

Plate IX, figs. 9a-b, 10a, b.

Shell rather strongly tapering, the rate varying from about 1 in 6 , to 1 in 7 , with the cross-section either subcircular to suboval, and the siphuncle nearly centran, or circular with the siphuncle slightly excentric. The dimensions of the lower end of a well-preserved section (Plate IX, fig. 9b) are: transvese diameter, $17 \mathrm{~mm}$., distance from center of siphuncle to ventral (?) side, $7 . \mathrm{mm}$..

Siphuncle strongly nummuloidal, giving the shell an Actinuceras-like appearance, but without the regular siphonal fillings characteristic of that genus. In one speeimen (Plate IX, fig. 10a) the siphuncle appears to have been wholly empty, becoming filled with the fine matrix of calcilutyte, in which the shell was embedded. This, in the lower two nummuli preserved, las separated out, showing the inside of the wall of the nummulus which is quite regular and fairly smooth. In a second, larger, specimen (Plate IX, fig. 9a, b) the nummuli are filled with coarsely crystallized calcite, the outlines of which are distinct from the walls of the nummuli. 
Diameter of nummuli varying from 5 to $5.5 \mathrm{~mm}$. and their length, which is also the septal interval, from $2.7 \mathrm{~mm}$., where the diameter of the shell is from 16 to $18 \mathrm{~mm}$. (Plate IX, fig. 10a), to $3 \mathrm{~mm}$. or a little over, where the diameter is $20 \mathrm{~mm}$. (Plate IX, fig. 9a). Depth of septa a little more than one camera length. Pseudosepta and stereoplasmic deposits in the camerse very irregular.

This species differs from the others of this genus in its suboval section, nearly centran siphuncle, and short septal interval, as well as in its irregular pseudosepta and stereoplasmic deposits. From S. machiakounense it differs, moreover, in the strongly nummuloidal siphuncle, the nummuli of which are much broader than long, whereas it is the reverse in S. machiakounense. From S. pseudoseptatum it differs in its smaller size, in the subcentran position of the siphuncle, and in the irregularity of the pseudosepta and stereoplasm; also in the regularity of the siphonal nummuli, and their complete freedom from deposits of stereoplasm. The species might easily be mistaken for an Actinoceras, but the absence of annular deposits shows that it belongs to the Loxoceratidie.

Horizon and Localities: In the Machiakou limestone of early Upper Ordovician (Black River) age at Kushan, Chihli, and at Wên-nan Mon-Yin-Hsien Shantung (V. K. Ting coll.).

\section{Family ACTINOCERATIDAE Srmann.}

\section{Genus ACTINoceras Bronn}

The type of this genus is Actinoceras bigsbyi Bronn, a widely distributed American species, which oceurs in the late Middle and early Upper Ordovician (Stones River, Black River and Trenton). It ranges from Tennessee northward to aretic America (Iglook Island, Fox Channel), westward to Iowa and Lake Winnipeg, and eastward to New York. The shell expands rapidly at first forming an irregularly conical apical end which is characterized by a large foramen, surrounded by a distinetly swollen ring. This feature has been figured by Foord for A. bigsbyi from aretic America and Canada, and it is equally well shown in a specinen of $A$. tani in the survey collection (Plate VII, figs. 7a, b). The apical cone of Actinoceras, in the specimens figured by Foord, and in our form, is somewhat asymmetrical. In the American form the apical foramen or scar is moreover situated obliquely, while in the Chinese form it is normal to the axis. This foramen apparently marks the point of decortication of the embryonic chamber or protoconch. 
After the initial rapid expansion, the rate of increase of the tube is diminished, being in some cases more nearly that of an ordinary Orthoceras, but more rapid in others so as to produce a very stout structure. In some cases as in $A$. vichthofeni the rate of expansion diminishes again after a while so as to produce a more cylindrical final portion. In rare cases the form is slightly curved. The cross-section varies from circular to oval.

The siphuncle. This is generally large and inflated in the camerse so as to produce a pronounced nummuloidal character or a succession of nummuli. * In size the siphuncle varies from less than one fourth to more than half the diameter of the conch. In the rapidly expanding apical end of the shell the siphuncle quickly reaches a large size and thereafter expands very little if at all, although the diameter of the shell may increase. Thus in the older part of $A$. richthofeni the siphuncle may occupy more than half the diameter of the shell, while in the expanded portion it does not occupy much more than one third that diameter. In position the siphuncle is centran or excentric even submarginal, though it is not always possible in sections to determine with certainty that the centran appearing position is not due to the manner in which the section is made.

The walls of the siphuncle are thickened by secondary deposits of carbonate of lime. Frech (Richthofen Vol. V. Plate 2 fig. 1) has illustrated a section of A. crassiventrum Wahl. which shows the manner of thickening of the siphuncular wall. According to this, the portions opposite the ends of the septa and those in the inflated portions in the camere are thickened independently, the former in advance of the latter. As a result of this addition of new material, the central cavity is reduced to a narrow central tube or endosiphuncle, from which lateral annular diverticula extend into the inflated portion of the siphuncle. Frequently the thickening has progressed so far that the whole or nearly the whole of the inflated portions (i. e. the diverticula) become filled solidly, leaving only a central more or less cylindrical tube, the endosiphuncle. This is the case in the majority of specimens of $A$. tani and $A$. richthofeni though the specimen figured by Frech (Richthofen V. Plate 2 fig. 8a,) still shows the presence of these lateral diverticula.

In some forms, as in $A$. richthofeni, the deposition of stereoplasm in the siphuncle is more pronounced in the anterior portion, this resulting in the formation of oblique diverticula from the central tube. This is fully described and illustrated under $A$. richthofeni (See text fig. 19, p. 79, and Plate IX, fig. 4.)

$\Lambda$ specimen of A. richthofeni in the collection of the Survey, shows the interior of the siphuncle in a fair state of preservation and unfilled by foreign material, the former 
filling having been removed by weathering. From this specimen it appears, that the thickening is not uniform all around the periphery of the siphuncle but rather in the form of bead-like enlargements. (Plate VII, fig. 3). This seems to be analogous to the structure of the siphuncle of $A$. bigsbyi figured by Foord (Cat. Foss. Cephalopoda Brit. Mus. Plate I. pp. 164-165 figs. 20-22) where a series of tubuli run from the endosiphuncle to the outer rim of the intra-cameral expansions, $i$. e. the nummuli. These tubuli have also been observed in specimens of $A$. tani from the Chinese rocks, and probably represent a feature usual in this genus.

According to Foord, the central tube or endosiphuncle is provided with a distinct wall of which the tubuli are diverticulations. Their number has been estimated by Bronn as 16 in $A$. bigsbyi, but the number of foramina figured in this species by Foord is very much greater. Those so far observed in Chinese specimens are few, probably not more than 16.

The significance of these tubes and foramina is not clear. Owen (Palæontology, 1860 p. 85) suggested that they may have served for the passage of blood-vessels to the living membrane of tise septal chamber, which would imply that these chambers were not merely empty spaces, cut off as in Nautiloids generally. The thickenings of the wall of the siphuncle were regarded by Hyatt "as strictly homologous with the successive sheaths of the endoseptum of Piloceras and Endoceras". I would however interpret the endocones of the Holochoanites as the crowded septa of an inner shell, comparable to an orthoceracone, which would make them entirely distinct from the thickening of the siphuncle of Actinoceras.

Suggestions have repeatedly been made regarding the significance of these siphuncular thickenings. Frech suggests that the thickening represents an attempt to render mechanically weak cylindrical structures more resistant against wave and current attack, the siphuncle thus being transformed into a supporting structure, or into a species of back-bone. That the solidified siphuncle became such a supporting structure, and that because of it the genus Actinoceras was a long-lived one, extending from the Ordovician to the Carboniferous, may be conceded, though it is by no means certain that Actinoceras as now understood is monophyletic. In other words it is not improbable that the Actinoceras type of siphuncle was independently developed in more than one phyletic series, representing thus parallelism in development, rather than genetic relationship. The origin of the structure however must be sought in the purely mechanical processes of lime separation as the result of the decay of the cells of the older part of the siphuncle, the gradual contraction of which was a concomitant plsenomenon of the functional detereoration of that part of the animal's anatomy. I would regard this excessive lime 
separation rather as evidence of senescence, and consider the Actinoceran type a phylogerontic phase of orthoceraconic development.

The apertural end of the siphuncle. A specimen of A. richthofeni from Huo-Luh, Chihli provinee, presented to the Survey collection by Miss Clarke, shows a section of the apertural end of the siphuncle (Plate VII, fig. 2). This has a maximum diameter of $12 \mathrm{~mm}$. and shows a conical depression about $25 \mathrm{~mm}$. in depth and $8 \mathrm{~mm}$. across at the upper end. The sides of the apertural cone are formed by the obstruction rings or rosettes of stereoplasm deposited about the septal necks, this deposit being slight in the upper part and increasing in thickness downward. This gives the inner surface of the cone an undulating appearance, contracting at the septal nęcks, and expanding between the septa, in conformity with the expansion of the siphuncle. The continuation of the cone in the endosiphuncle is not shown in the section, but undoubtedly existed. The funnel-shaped apertural end of the endosiphuncle resembles that of the Silurian genus Discosomes Hall, but there is no lining membrane or sheath as in that genus. It merely represents the still unfilled portion of the siphuncle and shows that the filling by "obstruction rings" progressed regularly from behind forward. There are indications in the specimen that the camerre of the shell continued beyond the upper end of this cone thus suggesting that the upper end of the siphuncle consisted of a series of hollow nummuli. If this was the case, the upper portion corresponds in character to the genus Stereoplasmoceras and as it represents a more primitive stage in development through which the shell passed as a whole (the filling being subsequent to the formation of the nummuli) the suggestion lies near that Actinoceras is a derivative from Stereoplasmoceras, which in turn is derived from Loxoceras, and that from Orthoceras.

The septat thickening. In practically all of the specimens of Actinoceras from the Machiakou limestone, a striking thickening of the septa by stereoplasm or organic deposits of carbonate of lime has taken place, so that the camere are more or less completely filled by this calcareous deposit. Complete filling is rare, but has been observed in some cases, while in others the thickening has proceeded only far enough to fill about one half of the camerd. The thickening is most generally produced by addition of lime to the upper surface of the septum, but in other cases it appears to be added to the under side as well. It is however possible that this appearance is deceptive, and due to the irregularity of the septum, which bends forward before reaching the inter-nummuloid contractions of the siphuncle (see A. coulingi, Plate VIII, fig. 1 cat. no. 4). The deposit is very often thickest near the siphuncle, close to which it frequently thins away abruptly, leaving a subtriangular area next to the outer margin of the 
nummulus, which area was vacant space and has been filled in by the lime mud after burial of the shell. (Plate VII, fig. 6).

The material which forms the thickening of the septa is crystalline carbonate of line, similar in all respects to that which fills the nummuli of the siphuncle. It is readily distinguished from the mud-filling of the open spaces, which is a uniform dark calcilutyte.

The thickening of the septa is not uniform. In a specimen of A. coulingi (Plate VIII, fig. 1) it is comparatively slight in the young or apical part of the shell, becomes most marked in the middle portion, and is comparatively slight in the apertural or last-built portion of the shell. This feature is also shown in a specimen of $A$. tani (Plate VII, fig. 6). In this specimen the upper surface of the organic deposit is smooth though somewhat undulating, having the appearance of a definite secondary septum. In this species, the thickening increases slightly near the siphuncle, and then thins away very rapidly, generally with a concavity of surface.

That this lime-deposit is of organic origin, i. e. deposited by the animal which occupied the shell, is beyond question, for only by such an origin can the uniformity of the deposit be explained. That it was formed on successive floors of the living-chamber, $i$. e. that each deposit was formed before the next covering septum was built, seems to me also evident, for there is absolutely no indication that the cameræ were in subsequent communication with the animal, the small tubuli of the siphuncle notwithstanding. I would interpret the filling of the camere as a process strictly analogous to the filling of the "siphuncle" by similar crystalline lime in the Holochoanites, the "supplementary septum" or "pseudo-septum" which commonly terminates it, being comparable to the endosheaths (as are also the true septa). Thus after the formation of each septum, deposition of lime continued upon it for a time, after which, during a resting stage, a pseudoseptum in close contact with the crystalline lime was formed. This was followed by a forward movement of the animal in the shell, and the formation of a new septum, which thus was distant for a certain space (generally less than half the height of the camera) from the pseudoseptum and crystalline deposit. After that the deposition of crystalline lime recommenced upon the surface of the new septum.

Distribution. Actinoceras appears abruptly in the Ordovician rocks of Nortl America and north China. A doubtful species ( $A$ ? mendax Salter) has been described from the Durness limestone of Sutherlandshire (north Scotland), where it occurs in the higher beds (Balnakiel and Croisaphuil groups), a horizon representing essentially the Beekmantown or perhaps early Chazy of eastern North America. * The species has also been reported from Skye, and doubtfully from Newfoundland and the Mingan Islands. 
Most of the American Ordovician species occur in the Black River or early Trenton formations, though some range down into the Stones River (late Chazyan), and others up into the Galena limestone (late Trenton) or eveu into the Cincinnatian. Their geographical distribution ranges from the south central United States to the Arctic regions. No species is known from the Ordovician of Europe with the exception of the Scottish form noted, but the formation in which this occurs, is an extension of the North American, not of the typical European Ordovician. * In the Silurian on the other hand, this species is not uncommon in western Europe as well as in North America, and it again occurs, though less abundantly, in the Lower Carboniferous (Mississippian or Dinantian) of these countries, though this may possibly be a distinct development of Actinoceran characters in another genetic series.

In China the genus appears to be practically confined to the northern provinces, though Yabe describes and figures two fragments of undetermined species from Hsingshou Hsien, northwest of Ichang, Hupeh province. As the Ordovician of south China is much better known than that of north China, and as these are the only fragment so far obtained from the neighbourhood, though still to the north, of the Yangtze, it would appear that the genus is unrepresented in the south of China.

\section{Actinoceras richthofeni Firech}

Plate VII, figs. 1-3, Plate IX, figs. 4.8.

1911 Actinoceras richthofeni Frech, in Richthofen, China, Vol. V., p. 8, PJate II, fig. 4a (4b?).

This species was figured but scarcely described by Frech, who merely states that the siphuncle is subcentral in position and occupies about one-third of the diameter of the shell. His illustration shows rather strongly concave septa about $3.4 \mathrm{~mm}$. apart, while the siphuncle has a fairly rogular diameter of $14 \mathrm{~mm}$. in the large end, which is 36 $\mathrm{mm}$. in diameter, and $12 \mathrm{~mm}$. in the smaller end, which is $20 \mathrm{~mm}$. in diameter. The distance betwcen the two measured points is $46 \mathrm{~mm}$., giving a rate of tapering of nearly $1 \mathrm{~mm}$. in 3 , though this is only approximate, as it is not certain that the section is parallel to the axis of the shell.

Shell oval in section, the two diameters being as 1 to 1.4 in the younger, and as 1 to 1.5 in the more mature portion; tapering at the rate of 1 in 3, or 1 in 3.5 laterally, but 
only at the rate of 1 in 6 or 7 dorso-ventrally. Shell-surface apparently with longitudinal flexuous strie; sutures somewhat flexuous, slightly arching forward on one of the sides. Average distance between camere $3.75 \mathrm{mrn}$., less in the younger stages. Depth of camere, in center, equal to about 3 canera-lengths or slightly more. Siphuncle nummuloidal, large, centran, and oval in section, corresponding to the section of the shell. It increases less rapidly in diameter than does the shell, its lateral diameter being $14 \mathrm{~mm}$. where that of the shell is $41 \mathrm{~mm}$., (Plate IX, fig. 7); and $10 \mathrm{~mm}$. where that of the shell is $30 \mathrm{~mm}$. while its dorso-ventral diameter is $11.5 \mathrm{~mm}$. where that of the shell is 28 $\mathrm{mm}$., and $9 \mathrm{~mm}$. in the younger stage, where that of the shell is only $24 \mathrm{~mm}$. (Plate IX, fig. 8). It is thus more nearly circular in section in the younger stages. Siphuncle as a rule only partially filled by rosettes of stereoplasm, leaving a large central tube, from which lateral, more or less forward-bonding diverticula extend into the nummuli.* Camere only partially (seldom entirely) filled with secondary stereoplasm.

The most complete specimen obtained is a fragment of the lower part of a large eonch preserving 12 cameræ complete and portions of 3 others. This specimen is shown on Plate IX, figs. 7a-7e, and clearly shows the oval section which in the upper part is 41 $\mathrm{mm}$. in lateral, and $27 \mathrm{~mm}$. in dorso-ventral diameter. Three views of the specimen were drawn $(7 \mathrm{a}-7 \mathrm{c})$, after which it was sectioned, the two sections being shown in figs. $7 \mathrm{~d}-7 \mathrm{e}$. The form of the siphuncle corresponds to that of the shell, and its two diameters at the upper end of the fragment are each about one third that of the corresponding diameter of the shell. The nummuli are only partially filled with rosettes of stereoplasm, lenving a large median tube from 2 to $2.5 \mathrm{~mm}$. in diameter. At the lower end of the specimen the diameter of the lower nummulus is $11.5 \mathrm{~mm}$., the form being practically circular. At the upper end, the nummulus, next to the highest complete nummulus, has a diameter of $15.3 \mathrm{~mm}$. while the highest completely preserved one, has a diarneter of only $14 \mathrm{~mm}$. Here the dorso-ventral diameter is also $11.5 \mathrm{~mm}$. This shows that while there is in general an increase in diameter laterally, there is also some variation. From the median tube, a lateral tube traverses the center of each nummulus, in some cases extending outward approximately at a right angle, in others bending slightly forward. Again it may bend forward and then outward as seen in the second nummulus from the top (fig. $7 \mathrm{e}$ ). In a few cases the opening of this tube in a pore on the periphery of the nummulus is well shown in the sections.

The septa are thickened by secondary stereoplasm, which appears to occur both on the upper and under side of the septum, though this feature is somewhat obscured by 
the development of crystalline calcium carbonate of inorganic origin in portions of the camers, especially on one side of the siphuncle. Pseudosepta generally define the stereoplasm. Some cameræ were however empty, having been filled by the matrix only (a fine brownish calcilutyte) which also fills the median tube.

Only traces of the shell are preserved which appears to have been rather thin, and marked by more or less flexuous longitudinal strix.

In a fragment of a smaller (younger) individual from the same locality (Plate IX, fig. 8) the sides are more sharply acute (slightly aceentuated by pressure in the specimen), while the siphuncular nummuli are proportionately larger and have a nearly circular transverse section. The dorso-ventral diameter of the interior of the shell (the septate stone-mold) at the largest end preserved, is $24 \mathrm{~mm}$., and its transverse diameter about $34 \mathrm{~mm}$. while the corresponding diameters of the siphuncle are 9 and $10 \mathrm{~mm}$. respectively. The depth of a single camera in this specimen is $12 \mathrm{~mm}$. where its short diameter is $22 \mathrm{~mm}$. The septal interval at this stage is slightly smaller than usual, being on the average $3.33 \mathrm{~mm}$.

Becnuse of the oval transverse section of the shell, the specimens practically always lie upon one of their broader sides, and hence the weathered sections always expose the transverse diameter of the shell, and the tapering seen is that of the lateral margins, and hence the greater of the two. A dorso-ventral section, if obtained, would show a very different rate of tapering, and a much narrower shell. The great depth of the camerse would however appear in such a section as well.

A larger specimen of this species from Tangshan (Plate VII, fig. 1), is $111 \mathrm{~mm}$. long but incomplete at both ends. At the widest part preserved, it is $46 \mathrm{~mm}$. in width, while at the lower end it is $24 \mathrm{~mm}$. wide, the distance between these points being 66 $\mathrm{mm}$. This gives a rate of tapering of $1 \mathrm{~mm}$. in 3, essentially the same as that of Frech's figured specimen. The diameter of the siphuncular nummuli in this wider part is about $16 \mathrm{~mm}$., or about one third the width of the shell. In the lower part it is about 13.5 $\mathrm{mm}$, and therefore more than half the width of the shell.

The septa are about $3.8 \mathrm{~mm}$. apart in the upper, and $3.6 \mathrm{~mm}$. in the lower part. In a specimen on the same slab with the one just described, the interior of the siphuncle is well preserved (Plate VII, fig. 3). This shows that the secondary deposits at the inner ends of the septa are not continuous all around the siphuncle, but form a series of rounded thickenings, there being about six of these to the circumference, judging from the number shown in the specimen, which is one longitudinal half of the shell. This accounts for variation in thickness of these inner deposits, as observed in different 
sections; seetions through the centers of two opposite beads would show the greatest amount of thickening, while sections through the depression between the beads would show the least, others falling between these.

In the majority of specimens the septa show secondary thickening, either on one or on both sides. This is however seldom if ever as extensive as in A. tani. In some cases, indeed, it is scareely developed, or is strongly developed on one side only, as in the type figured by Frech (loc. cit. Plate 2 fig. 4a). The bowl-shaped depression which is formed around the siphunele by the abrupt oblique truncation of the deposit near the siphunele, in such species as $A$. tani and some others, is seldom developed. I have not seen it in perfection in any specimen of this species, though it occurs in individual septa. Not infrequently the deposit widens towards the siphuncle, and comes in close eontaet with it. One or two pseudosepta are commonly present in each eamera charaeterized by such deposit. One may divide the deposit into two parts, and the other terminate it, after which there is an interval represented by an empty space (filled, except in weathered specimens, by the rock matrix $*$ ) and then a new septum follows.

In some eases the stereoplasm is included between the septum and a pseudoscptum next in front (see fig. 6 Plate IX). Again there may be a slight deposit of stereoplasm both on the upper and under sides of the septum, but this is generally irregular, especially on the under side, as if the septum had been broken. Thickening by stereoplasm on both sides of the septa is indieated in Frech's figure of the type, but I have not seen any specimen in which the thickening is as regular as is shown on the right side of his figure. A fragment which I refer to this species (Plate IX, fig. 5) has the eameræ nearly filled with stereoplasm, the septa appearing out of position, ending apparently against the nummuli. This would give the appearance of Frech's figure, if we assume that the septa are pseudosepta, and that true septa oecur in the midst of the stereoplasm deposit. Of this there is however no indieation. In fact, the septa are strongly bent backwards, so as to rest for a space against the upper or frontal surface of the next preceding nummulus. If a deposit of stereoplasm exists on the under side of the septum it could hardly be explained otherwise, than by assuming its formation to have taken place after the formation of the septum, in which ease there must have remainer some organic connection between the eamera and the animal.

* It is a notewortliy fact, that the originally empty portions of the camerre are almost always filled with the rock matrix (generally in our specimens a calcilntyte) in which the shell as a whole is embedded. It does not seem likely that the lime-mud, fine though it was, could filter through the "endosipluncle" and the radiating tubules into there camera (no mud-filled tubules have been observed), and we therefore must conclude that it entered tlirough fractures in the onter shell, formd 110 doubt by crusling after burial. In some cases the shell is seen to have been worn away before final burial, and in such specimens of course all empty spaces were filled by the lime-inud, and in some cases even other foreign substances, such as fragments of other fossils, are enclosed. 
The inner tube of the siphuncle (endosiphuncle of authors) varies in diameter with the progress of siphuncular filling. In a specimen (Plate IX, fig. 4) in which the siphuncle has a width of $15 \mathrm{~mm}$, it is only $1 \mathrm{~mm}$. wide. In another (Plate VII, fig. 3), where the diameter of the siphuncle is about $11 \mathrm{~mm}$., the open central tube has a diameter of about $5 \mathrm{~mm}$. In the latter specimen, broad open diverticula diverge laterally, terminating in the centers of the nummuli, apparently in fine tubuli. In the former example, where the central tube has been narrowed to a diameter of $1 \mathrm{~mm}$., the diverticula are reduced to tubes which curve obliquely downwards and outwards. Thus the tube which terminates in a pore in the center of a nummulus, reaches the endosiphuncle at a point almost in the median horizontal plane of the nummulus next forward. This peculiar structure is seen in a weathered section from Lincheng, province

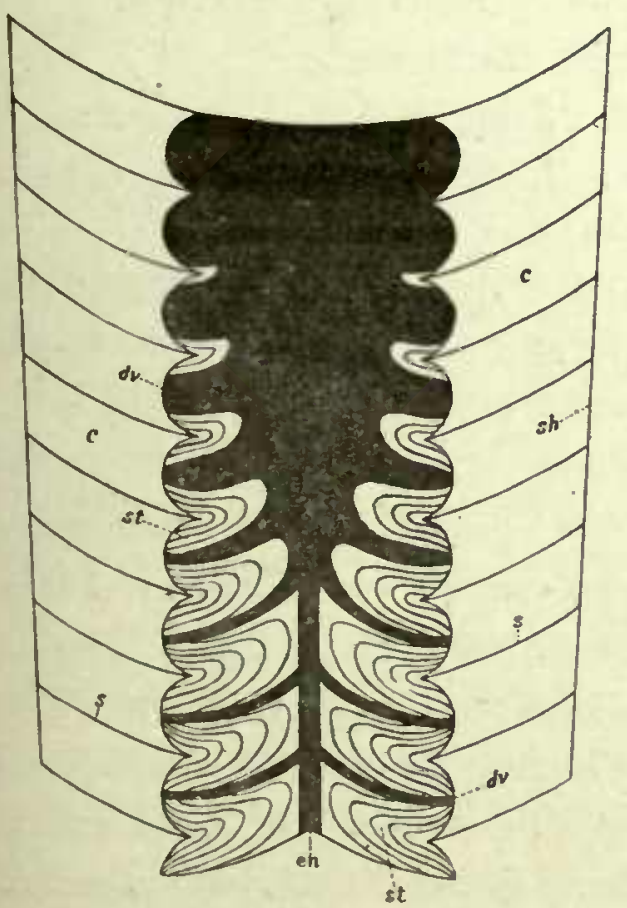

Fig. 19. Diagrammatic section of the part of a sliell of Actinoceras richthofeni represented on plate 1., tig. 4. drawn to scale. The by stercoplasm. In the upper part it is shown empty, suecessive layers of stereoplasm are aclejed, in sucl a way that the diverticnla from the central tube curve from the periphery of the nummuli forward or orad, as shown in the lower part of the figure, and in the drawing of the specimen (plate IX, fig. 4). Twice natural size. ( $c$, camerse; $d r$, diverticula of endosiphotube; en, endosiphotube; $s$, septa; $s h$, shell; st, stereoplasmic filling of nummuli). siplnuncle is here shown in the process of filling of Shantung, and appears also, but in a less marked degree, in the type specimen from Manchuria figured by Frech. It indicates that the deposition of material, was most pronounced on, and finally practically confined to, the anterior part of the floor of each nummulus as illustrated in text fig. 19. The deposits on the bottom of a single nummulus may be likened to a series of closely approximated superposed septa, the first slightly but normally concave, with a well-marked siphonal funnel, and thickened at the funneledge; each sueceeding septum becoming more thickened at the funnel-edge, and having its funnel end invaginated into that of the preceding one. In consequence of the thickening of the septum at the funnel-edge, the central portion would rise more and more, the septum curving upwards from the rim to the funnel-edge, until the center of the septum, still picreed by the funnel-holes, is higher than the rim. This would mean a progressive collapse of the siphonal expansions, until they represented only a thin double membrane. Some slight additions of lime have meanwhile been made to the inside of the upper (forward) surface of the inside of the nummuhis, by the upper surface of the siphonal expansion. Thus, what appears as a lateral tube in section, may in reality be the section of the space occupied by this collapsed siphonal 
expansion, which is more or less continuous across the siphuncle, and into which the several pores of the siphonal wall open. This is well shown in the specimen illustrated in fig. 4 Plate IX, where the end of the siphuncle has been severed off along one of these planes of weakness.

Aperturally the endosiphuncle terminates in a conical expansion, as described on page 73. It may continue beyond this in a series of hollow nummuli.

The mural pores of the siphuncle, if they are present in this species, are not well preserved. In a specimen in which they might be expected to appear prominently there appears to be no positive indication of them. This may be merely due to the manner of preservation, or the pores may in reality be absent, or may have been completely filled during the progress of shell growth.

So far as can be determined from the fragmentary material, the exterior of the shell is without ornamentation exeept fine flexuous longitudinal lines.

Comparisons. Frech compares this species with a fragment figured by Barrande * under the name Orthoceras (Actinoceras) richardsoni from Little Manitoulin or Cockburn Island Lake Huron, Canada, and ealls attention to the fact, that Barrande's specimen can not be regarded as belonging to $A$. richardsoni Stokes. This would suggest that the Chinese species, or a closely allied but unnamed species, also oecurs in the early Upper Ordovieian (Trenton) of North America. I know of no other deseribed species with which our Chinese form ean be compared.

Horizon and Localitirs: In the Machiakou (Upper Tsinan) or Actinoceras limestone, widely distributed in north China. The type comes from Hsiau-sörr, Fengtien, (Manchuria), and was collected by von Richthofen in 1869. Yabe cites the species as common at Kwa-sen-do, Ko-to-gun, Hei-an-nan-dö, in Korea.** In Chihli province it has been obtained from Tangshan, Machiakou, and Chaokouchuang, all in the Kaiping basin, and from Huo-Luh Hsien in the southwestern part of the province (by Miss Clarke). In Shantung provinee it has been found near Lin-cheng by Dr. F. F. Mathieu and at Seng Chuang, Ningyang district and Wên Nan, Monyin-Hsien, by Dr. Ting.

\section{Actinoceras tani Grabau (sp. nov.)}

Plate VII, figs. $4-7$.

Shell slender, tapering at a rate varying from 1 in 5 to 1 in 7 according to the direction of the section measured. Cross-section faintly oval. Siphuncle excentric, on 
the shorter axis of the section, and distant from the nearest shell-margin a variable amount, this ranging from about half, to a little more than its full diameter. From the opposite shell-margin it is separated between two to three times this amount. In a specimen from Tingshan (Plate VII, fig. 5, cat. no. 26) the diameter of the siphuncle is $5 \mathrm{~mm}$. where the shell is $22.3 \mathrm{~mm}$. in diameter, while in another specimen from Shantung, the sipluuncle has a diameter of 4.5 , the shell diameter being $17.5 \mathrm{~mm}$. (cat. no. 66). In the specimen illustrated in figure 6 Plate VII, (cat. no. 1), where the siphuncle is apparently centran, because of the position of the section, it retains a very uniform diameter of $6 \mathrm{~mm}$. while that of the shell ranges, at the point of the section, from 16 to $20 \mathrm{~mm}$. As this is a shell with excentric siphuncle,* the section does of course not represent the maximum diameter nor the true rate of tapering.

In a specimen from Chihli (Plate VII, figs. 4a, b, cat. no. 69) which shows the greatest rate of expansion observed ( 1 in 5 ), the siphuncle appears centran in longitudinal section, but the transverse section shows it to be about one half its diameter from the margin. The siphuncle is $8 \mathrm{~mm}$. in diameter where the shell in the same section is 24 $\mathrm{mm}$. The endosiphuncle (endosiphotube) is about $1.5 \mathrm{~mm}$. in diameter or a little more, and appears as a regular cylindrical tube. The septa average $2.6 \mathrm{~mm}$. apart. They are sometimes double, and the camera are largely filled with stereoplasm.

The nummuli, or expansions of the siphuncle in the camers, are generally regular and symmetrical, though now and then one is shorter, or of smaller diameter. When well exposed, the peripheral mural pores may be seen, ranged around the ambitus of the nummulus. In a specimen from Tangshan (Plate VII, fig. 7c), they are small, and each is situated at the summit of a low pustule, the pustules being separated by a space equal to about twice their diameter. I estimate their number on a single nummulus to be about 24 .

The septa are strongly thickened by the addition, on the upper side, of stereoplasm, which has a crystalline structure and is terminated by a smooth-surfaced supplementary septum or pseudoseptum in each camera. . The thickening proceeds to within a short distance of the siphuncle, when it dies away abruptly, the pseudoseptum sloping steeply and generally concavely to the septum, which latter joins the siphuncle in the constriction between the nummuli. Thus a sort of saucer-like depression is formed around each nummulus, which appears to lie in it like the pudding in a disls.

The thickening, by stereoplasm, is not uniform inflsuccessive camerx, nor within the same camera. As will be seen from the natural section of the specimen illustrated in 
figure 6 on Plate VII, the same camera may show a thickening on one side to the extent of half the height of the camera, while on the opposite side the thickening may fill nearly the whole of the camera. In a general way, there is a decrease in the amount of the deposit from the older septa forward to the younger.

The apical end of this species is shown in a specimen from Tangshan (Plate VII, figs. 7a,b). This begins with a somewhat asymmetrical subconical initial chamber, about $9 \mathrm{~mm}$. in depth. At its apex is the large siphuncular foramen, surrounded by a swollen annulus, the whole producing an apical mammelon, about $7 \mathrm{~mm}$. in basal diameter. The central scar or siphuncular opening is about $3.5 \mathrm{~mm}$. in diameter. At its upper end the initial chamber has a lateral diameter of $16.6 \mathrm{~mm}$. and a dorso-ventran of $16 \mathrm{~mm}$. The mammelon lies to one side of the lateral, but, on the dorso-ventral axis. Above the initial chamber the ventral (?) side (side nearest to which the siphuncle lies) becomes faintly concave longitudinally as if the shell were taking on a cyrtoceraconic form. This continues for about five chambers after which it disappears and the surface slope is normally orthoceraconic. Almost from the first the septa average $3 \mathrm{~mm}$. apart at the suture, their concavity being equal to about the depth of one camera. This early portion of the shell has a somewhat greater angle of divergence than is characteristic of later stages, being about 1 in 4 .

\title{
Surface features of shell unknown.
}

This form is readly distinguished by its slender character, gentle rate of tapering, septal distance, character of stereoplasm and excentric siphuncle. The latter is not however always seen in its true relation in longitudinal section, for if this is normal to the dorso-ventral axis the siphuncle appears centran as in fig. 6 Plate VII.

Horizon And Locality: A. tani is probably as common as, if not more so than A. richthofeni, and occurs in practically the same localities, in the Machiakou limestone. Specimens have been obtained from Tangshan (F. K. Morris, G. B. Barbour), Machiakou (H. C. T'an), and Chaokouchuang (Survey expedition) Chihli; from Lincheng, from Chan-chin-Hsien, and elsewhere in Shantung (F. F. Mathieu, J. G. Andersson and V. K. T'ing) and from Chilio, south of Shih-T'ou Chiang, Chibli (G. B. Barbour). The specific name is given in honor of Mr. H. C. T'an of the Chinese Geological Survey.

\section{Actinocerás coulingi Grabau (sp. nov.)}

\author{
Plate VIII, figs. 1, 2.
}

1903 Actinoceras (Ormoceras) aff. tenuiflum Hall. Crick, Geological Magazine N. Ser. Dec. IV, Vol. X, p. 481, pl. XXII fig. C. 
1920 Actinoceras (Ormoceras) sp. indet. Yabe, Palæontology of Southern China, pl. XIX fig. 9. (not pl. XVIII fig. 12).

Shell large, tapering at the rate of about 1 in 5 to 1 in 5.5. Siphuncle centran or nearly so, increasing very slowly in diameter, the nummuli strongly flattened above and below so as to be in contact with the septum for nearly one fourth their width on all sides. At a point where the shell is $24.2 \mathrm{~mm}$. in diameter, the siphuncle is $8.5 \mathrm{~mm}$. (Plate VIII, fig. 2, eat. no. 27). In another specimen (Plate VIII, fig. 1, eat. no. 4) the diameter of the siphuncle is $9.5 \mathrm{~mm}$. where that of the shell is $25 \mathrm{~mm}$; and $11 \mathrm{~mm}$. where that of the shell is $31 \mathrm{~mm}$. the rate of tapering being about 1 in 20 to 1 in 22 . Septa regularly concave, their depth at the center being equal to $1 \frac{1}{2}$ or $1 \frac{3}{4}$ camera, and their distance apart about $3 \mathrm{~mm}$. or somewhat more, where the shell is about $30 \mathrm{~mm}$. in diameter. Camerre mostly filled with stereoplasm which often has the appearance as if it were deposited on both sides of the septum (See Plate VIII, figs. 2, cat. 12o. 27). I have, however not been able to satisfy myself that this is actually the case. Instead it would appear that the septa are more or less undulating, partly so away from the sipluuncle, but more usually near it, where there is sometimes a marked annular depression of the septum, so that it ecmes to lie almost opposite the ambital portion of the nummulus. In other cameras again this depression is not seen, and sometimes in section one side appears regular while the other shifts backwards. Commonly the stereoplasm fills the camera almost or quite to the siphuncle and completely to the next succeeding septum. In other cases however, where the septa maintain their normal position, the stereoplasm stops before reaching the siphuncle, leaving a saucer-shaped depression around the nummulus as in $A$. tani.

The specimens on which this description is based, agree in all essentials with the photograph of a specimen collected by Samuel Couling M. A. near Ching Chow Fu, Kiao-chow, provinee of Shantung, and figured by G. C. Crick (loc. cit.) on his Plate XXII, fig. C. His specimen may have been larger than ours, for the scale is not indicated, but the proportions are essentially the same, the siphuncle being $15.8 \mathrm{~mm}$. where the shell is $47 \mathrm{~mm}$. and the septa $3.3 \mathrm{~mm}$. apart. Crick compares his specimen with $A$. tenuifilum Hall of the Black River beds of North America. In that species, however, the sipluncle is proportionately broader (the proportions being about as 1 to 1.9, whereas in the Chinese species, they are as 1 to 2.8). The septal interval is also greater, being in the American species 7 to $7.5 \mathrm{~mm}$. where the shell is $27 \mathrm{~mm}$. wide, the proportions of depth of camera to diameter being approximately as 1 to 6.5 instead of ranging between 1 to 8 and 1 to 10 , as in the Chinese species. In $A$. tenuifilum the septa are also 
frequently displaced apicad and made to appear double by the development of pseudosepta.*

Crick describes a specimen from the Couling collection, apparently of this species, which bas a length of $95 \mathrm{~mm}$., and a maximum width of $50 \mathrm{~mm}$. tapering very slowly, and with a siphuncle at that point about $24 \mathrm{~mm}$. in diameter. He describes the cameræ as $11 \mathrm{~mm}$. high, but that seems out of all proportion to the shell, (boing as 1 to 4.5 as compared with 1 to 8 or 1 to 10 in the typical forms) and would argue a rapid elongation of the chambers with the growth in length of the shell.

Horizon and Locality: This species has been obtained from the Machiakou (Actinoceras) limestone of Hsi-Hsien, province of Honan, (L. C. Taun), from Machiakoll, Luan Hsien, Chihli province (H. C. T'an), and.from Lincheng, Shantung provinec (F. F. Mathieu). The specimen collected by Samuel Couling, came from Ching Chow $\mathrm{Fu}$, Kiaochow, Shantung. Yabe (loc. cit. Plate XIX, fig. 9) figures a specimen of Actinoceras from No-lu-ping Hu-ch'i, Hsing-shan-Hsien, province of Hupeh, which may belong to this species, though the specimen is in a very imperfect condition. The other specimen figured by Yabe (Plate XVIII, fig. 12) from Pan-tse-ya, same district and province does not belong here, the septal interval being proportionately much greater than is normal for this species, while the siphuncle is submarginal.

The specific name is given in honor of Samuel Couling, A. M. Editor of the China Review, Shanghai, who first brought to the notice of scientific men the oceurrence of the genus Actinoceras in the Ordovician rocks of China, and to whom the Survey is indebted for courtesies in connection with these studies.

\section{Actinoceras suanpanoides Grabau (sp. nov.)}

Plate VIII, figs. $3 a, b, 4 a, b$; Plate IX, figs. $1 a, b$.

Shell slender, tapering at the rate of about 1 in 5.5 ; section apparently oval, with a slight flattening on the ventral side. Siphuncle excentric nearest the flattened side, from which it is separated by a distance equal to about half its diameter. In the early stages the siphuncle occupies more than half the diameter of the shell ( $\frac{2}{3}$ in some cases?) but later the proportional diameter is not much over one-third that of the shell. The nummuli are somewhat flatter on the forward as compared with the posterior end and the 
endosiphuncle scems to be obliterated by filling. Camere fairly uniform, their length averaging perhaps $3.5 \mathrm{~mm}$. where the shell has a diameter of $15 \mathrm{~mm}$.; nor do they materially increase with the increase in the shell diameter to $20 \mathrm{~nm}$. Their concavity is nearly equal to the depth of two chambers. Stereoplasmic filling of the camcra is pronounced in the earlier part of the shell, but becomes less so in the later cameræ. For the most part it is added to the anterior portions of the septa, but in some cases it appears also to be added to their posterior surfaces, but this is very irregular and may be a secondary deposit. The septa are sometimes undulating, in some cases bending back nearly to the center of the nummulus of the preceeding camera. In some cases the stereoplasm ends near the siphuncle in a saucer-like surface as in $A$. tani, while in other cases it extends nearly or quite to the nummulus. In still other cases it is more weakly developed in one part than in another of the same camera (see the section Plato VIII, fig. 3).

\section{Outer surface of shell unknown.}

This species has the general form and character of $A$. tani, but the camere are about half again as long as in specimens of that species of the same diameter, and the concavity of the septa is much greater. The stereoplasmic filling is also more irregular in the present species than in $A$. tani.

A fragment of a shell $8 \mathrm{~cm}$. in length, and apparently of this species was obtained from Wên-Nan, Mon-Yin-Hsien, Shantung. This is figured on Plate IX (figs. 1 a-b). The rate of tapering is not ascertainable with aceuracy because the shell is slightly crushed on one side, but appears to have been about 1 in 7 . At the lower end of the fragment, where the diameter is about $19 \mathrm{~mm}$, the siphuncle has a diameter of about 8.5 $\mathrm{mm}$. whereas that of the sections figured is about $7 \mathrm{~mm}$.

The distance from the ventral margin is $3.5 \mathrm{~mm}$. that from the dorsal $7 \mathrm{~mm}$. Where the dianeter of the shell is $24 \mathrm{~mm}$., the distance of the siphuncle from the ventral margin is still $3.5 \mathrm{~mm}$. The average distance between the septa is $3.5 \mathrm{~mm}$. The sutures visible on the exterior of the inner mold, are somewhat undulating, extending forward on the ventral side (the side to which the siphuncle is closest) in a gentle saddle, to the extend of about 1 camera-length beyond the lateral and dorsal sides. In the earlier portion, this saddle is less pronounced, its increase in length thus corresponding to the proportional approach of the siphuncle to the ventral side. The concavity of the septa in the larger portion of the fragment is equal to about the depth of two caamer.

Horizon and Localities: In the Machiakou limestone of Tai-an, Shantung province. Survey collection. A small specimen apparently representing the apical portion of this species was obtained from Sen Chuang, Ning Yang, Shantung, and 
another from Lincheng, Shantung (F. F. Mathieu), and a fairly well-preserved internal septate mold from Wên Nan, Mon-yin-Hsien, Shantung (V. K. Ting).

The specific name is given in allusion to the Chinese calculating frame or Suanp'an (算 盤), to the elements of which, $i$. e. the single row of Chii (珠) the siphuncle of this species shows a marked resemblance.

\section{Actinoceras submarginale Grabau (sp. nov.)}

Plate VIII, figs. 5a, $b$; Plate IX, fig. 3.

Shell of medium size tapering at the rate of about 1 in 4 , the siphuncle submarginal and occupying about one-half the diameter of the shell or somewhat less, regularly swelling between the septa, and constricted at the septal openings to about two-thirds its width. Endosiphuncle large, its diameter about $3 \mathrm{~mm}$. where that of the siphuncle is 15 $\mathrm{mm}$. with deverticula extending into the nummuli. Mural pores not observed. The section of the shell is apparently suboval while that of the siphuncle is cireular. It is so close to the shell on one side, that it appears almost to touch it, but the septa are continuous around it, showing that the contact is not absolute. In form the siphuncle tapers gently, the rate being approximately 1 in 19 in a characteristic specimen.

The septa range from 4 to $4.7 \mathrm{~mm}$. apart and are, as a rule moderately concave, though, in one specimen (Plate IX, fig. 3, cat. no. 56.) some of them exhibit rather marked curvature, involving in some cases as much as the depth of two chambers. The space between the septa ranges from 4 to $4.4 \mathrm{~mm}$. in specimens of about thirty $\mathrm{mm}$. diameter. In a specimen sectioned so as to give the siphuncle a subcentran appearance, although it is in reality close to the margin (Plate VIII, fig. $5 a, b$ ) the septa are at first rather flat-lying, and somewhat undulating, after which, near the margin, they bend strongly forward (upward). In this respect the two specimens figured show a marked contrast, but it must be remembered that they show the shell in sections practically at right angles to each other.

The stereoplasm is variable. In one specimen (fig. 5) it fills the grenter part of the camera leaving only a narrow space beneath the next septum. The filling extends to the siphuncle and makes the entire shell a very solid and compact mass. In another specimen (fig. 3 ) the filling is comparatively slight, and the septa hence have weathered out in relief from the section and were readily broken away. 
Sections of this species made so as to give the appearance of a centran siphuncle (Plate VIII, fig. 5a) might be taken for $A$. richthofeni. They can however be readily distinguished by the slight depth of the eamerie. In a transverse section of eourse, the subcircular outline and submarginal position of the siphuncle readily distinguish this species.

Honizox and Localities: This species has been obtained from the Machiakou limestone of the Kaiping basin in eastern Chihli provinec. It has been found at Tangshan and more doubtfully at Machiakou (Survey expedition). A natural section, apparently of this species, has also been obtained from the same horizon at Wên-Nan, Mon-Yin-Hsien, Shantung (V. K. Ting coll.).

\section{Actinoceras nanum Grabaı (sp. nov.)}

PJate VII, fig. 8; PJate 1X; fig. 2.

Shell slender, the longest specimen observed being about $70 \mathrm{~mm}$. in length and $10 \mathrm{~mm}$. in diameter at the basal end. It tapers at the rate of about 1 in 4 . A second specimen (Plate IX, fig. 2) about $45 \mathrm{~mm}$. long, has a basal diameter of $6.5 \mathrm{~mm}$. and tapers at the rate of 1 in 5.75. A third specimen (Plate VII, fig. 8), the most perfectly preserved, lias a length of about $18 \mathrm{~mm}$., its basal diameter is $6 \mathrm{~mm}$. and its rate of tapering 1 in 4 .

Siphuncle centran, small, the greatest diameter of the nummuli being $2.1 \mathrm{~mm}$. where that of the shell is $9.4 \mathrm{~mm}$; strongly nummuloidal, contracting at the septa to a dianeter of $0.7 \mathrm{~mm}$. Endosiphuncle subcylindrical, about $0.6 \mathrm{~mm}$. in diameter.

Septa gently concave. In the best preserved specimen they are $1.3 \mathrm{~mm}$. apart where the diameter of the shell is $10 \mathrm{~mm}$. and practically the same where the shell diameter is $8.5 \mathrm{~mm}$. In another specimen, (Plate IX, fig. 2) the septal interval is $1.6 \mathrm{~mm}$. where the shell diameter is $10 \mathrm{~mm}$. and that of the nummuli about $2 \mathrm{~mm}$.

Stereoplasm slightly developed or almost absent. When present, as in fig. 8 Plate VII, it is thickest near the siphuncle, but thins away rapidly before reaching this.

This species is readily recognized by. its tapering to a very narrow end which is 6 $\mathrm{mm}$. or less, a diameter found in no other species in these rocks; by the very approximate septa (from 1.3 to $1.6 \mathrm{~mm}$. where the shell is $10 \mathrm{~mm}$. in diameter); and by the minute centran siphuncle, which is smaller than that of any other species known from these rocks. 
Horizon and Localtir: This species has so far been found only in the Machiakou limestone of Tangshan in the Kaiping basin, eastern Chibli. It is less common than sone of the other spocies.

\section{Actinoceras curvatum Grabau (sp. nov.)}

Plate VIII, fig. 6.

Shell gently curved, with large siphuncle close to the convex side, though not in contact with the shell. The diameter of the siphuncular elements or nummuli, in the only known specimen, is $12 \mathrm{~mm}$. and their length $2.4 \mathrm{~mm}$. giving a proportion of 1 to 5 . They are moderately contracted at the septal crossing so that their narrowed portion is about $8 \mathrm{~mm}$. in diameter. Diverticula from the endosiphuncle (the latter not exposed in the sepcimen) extend nearly to the outermost margin of the nummulus where there appear to be rather widely-spaced mural pores, which are, however, not well shown except now and then in one or another of the nummuli.

There is some variation in the length of the individual nummuli, but no appreciable change throughout the part of the shell shown, which is about $80 \mathrm{~mm}$. long. The average length of the nummuli remains the same so far as exposed, but the diameter apparently decreases somewhat apicad, but this can not be determined with certainty. The width of the shell cannot be ascertained but judging from the septa preserved, it could not be less than $20 \mathrm{~mm}$. in the lower part, and probably was $25 \mathrm{~mm}$. The septa are strongly oblique towards the siphuncular side. If the curvature was regular, with a sliell width of $25 \mathrm{~mm}$., the depth of the septa was equal to that of two cameræ.

Whilo the septal distance in the upper part of the shell was presumably that of the nummuli-length, or $2.4 \mathrm{~mm}$. on the average, it was somewhat greater in the earlier part of the shell, where the septa are preserved. There the average is $2.7 \mathrm{~mm}$., some of the septa being separated by as much as $3 \mathrm{~mm}$.

Stereoplasmic thickening of the septa is moderate, bcing confined to the upper surface of the septum and occupying one-half of the septal interspace or less. It is irregular, swelling in some parts, and thinning away in others. It seems to be least developed on the inner or concave side. It was apparently bounded above by a pseudoseptum.

Horizon and Locality: A single imperfect specimen has been obtained by Dr. F. F. Mathieu from the Machiakou limestone of Lincheng, province of Shantung. Though imperfect, it is thought worthy of description, as it is tho only curved Actinoceras 
known from these rocks. The species is placed in the genus Aclinoceras rather than Cyrtactinoceras, because of its slight curvature, moderate tapering, and large actinoceran siphuncle. Another smaller specimen with narrower siyhuncle ( $9 \mathrm{~mm}$. where shell is 15 $\mathrm{mm}$. wide), but otherwise similar, and also showing slight curvature, has been obtained from the same horizon, south of Wên-Nan, Mon-Yin-Hsien, Shantung. (V. K. Ting coll.)

\section{Genus Cyrtactinoceras Hyatt.}

This genus, founded by Hyatt, with Cyrtoceras rebelle Barrande as the genotype, was more fully defined by Ruedemann (N. Y. State Museum Bull. 90, 1906, p. 488), who referred to it two species from the Chazy limestone (Middle Ordovician) of the Lake Champlain region in eastern North America. They are rather short and stout cyrtoceracones with highly nummuloidal siphuncle, characterized as in Actinoceras, by stcreoplasm which is arranged as obstruction rings or "rosettes" around the septal necks. The camers too are filled with stereoplasm, this being very extensive in one of the Chazy species. In the type of the genus, the section is depressed, the septa rather elosely arranged, the siphuncle moderately nummuloidal shrinking somewhat in old age, and filled in the middle stages with rosettes. It is near the convex side of the conch, but somewhat variable in position, approaching the center again in old age (Ruedemann).

From curved forms of Actinoceras the species of this genus may be distinguished by their rapid enlargement, this producing relatively short stout shells. The siphuncle of the curved Actinoceras species is also much larger in proportion than is that of Cyrtactinoceras.

\section{Cyrtactinoceras frechi Grabau (sp. nov.)}

Plate VIII, figs. $7-10$.

Shell a comparatively small breviconic cyrtoceracone of subeireular or somewhat oval section and gentle curvature, the shorter of the two transverse axes in the plane of curvature. The shell tapers at the rate of 1 . in 2.5 in the early stage, having a transverse diameter of $10 \mathrm{~mm}$. at the second septum, below which it is rounded off acutely. Seventeen millimeters above the second septum it has a transverse diameter of $18 \mathrm{~mm}$. while the 
shorter axis measures $15 \mathrm{~mm}$. At this point the siphuncle is situated about $4 \mathrm{~mm}$. from the convex side and has a diameter of $4.5 \mathrm{~mm}$. being approximately circular in section. The increase of the shorter axis in another specimen (Plate VIII, fig. 7 eat. no. 2 ) is from $9 \mathrm{~mm}$. to $13 \mathrm{~mm}$. in the space of $17 \mathrm{~mm}$. giving a rate of tapering of $1 \mathrm{in} 4.25$. In this specimen the siphuncle has a diameter of about $4 \mathrm{~mm}$. at the lower end, not changing appreciably throughout. Its distance from the outer margin of the upper end of the specimen is about $4 \mathrm{~mm}$. but it is only about 2 or $2.5 \mathrm{~mm}$. from this margin at the lower end. In a specimen from Chaokouchuang (Plate VIII, fig. 8) with a shorter diameter of about $10 \mathrm{~mm}$. at the base, the siphuncle is $2 \mathrm{~mm}$. from the outside and has a diameter of $3 \mathrm{~mm}$. or a little more. The transverse diameter here is about $11.5 \mathrm{~mm}$. Fourteen millimeters higher, these diameters are 12 and $15 \mathrm{~mm}$. respectively, giving rates of tapering of 1 in 7 and 1 in 4 respectively. In a sectioned specimen from Shantung (Plate VIII, fig. 10) the diameter of the siphuncle is $4 \mathrm{~mm}$. where that of the shell is 15 $\mathrm{mm}$., and it is $2.5 \mathrm{~mm}$. from the convex side. In form it is strongly nummuloidal and filled with stereoplasm deposited in rosette form as in Actinoceras. There is a narrow subcentral endosiphuncle.

Septa from 2.6 to $2.75 \mathrm{inm}$. apart, of moderate curvature, and with comparatively little stereoplasm in the cameræ, this being most extensively developed on the convex side.

This speeies differs from the American Middle Ordovician (Chazy) species mainly in its excentric siphuncle, and longer cameræ in the young. It has much less stereoplasmic deposit in the chambers than has $C$. champlainense Ruedemann, and it curves less than does C. boycii Whitfield. A short section of the shell might easily be mistaken for a small species of Actinoceras.

Horizon and Localities: In the Machiakou limestone of early upper Ordovician (Black River) age at Tangshan, Machiakou, and Chaokouehuang, all in the Kaiping basin of eastern Chihli province, (Collections: 'T. C. Wang, H. C. T'an and Y. C. Sun respectively). Also from Chingchuang, Ning-yang district, Shantung province (coll. V. K. Ting).

The specific name is given in memory of the late Dr. Fritz Frech of Breslau Germany, to whom we owe the fifth volume of Richthofen's great work on China, and whose labors have done so mucl towards increasing our knowledge of the invertebrate fossils of China. 


\section{Genus Gonioceras Hall}

The presence of the genus Gonioceras in the Ordovician rocks of north China was first suggested by G. C. Crick * in his discussion of the fossils collected by Mr. Samuel Couling, M.A., Editor of the China Review, south of Tsing-tshou-fu (ChingChow-Fu) in Shantung. In his plate (fig. B) Crick gives a photographic reproduction of one of the specimens which, if uatural size, (the scale is not given) shows an actinoceran shell with apparently empty camere $2.2 \mathrm{~mm}$. long, and a strongly nummuloidal siphuncle, the nummuli of which are $15.5 \mathrm{~mm}$. in diameter. He further refers to a rubbing of another specimen, "about 25 centimeters long, displayed in section on the surface of a slab". Commenting on these specimens, he says "although the relative proportions of the parts of the shell, the relatively wide siphuncle and the very shallow chambers, agree fairly well with those of Actinoceras imbricatum Hisinger, sp. from the Silurian (Upper Ludlow) of the Island of Gotland, Sweden, it seems scarcely likely that an example of this species could be so worn down as to expose the siphuncle for a length of 25 centimerers ".** Crick therefore refers his specimen to the genus Gonioceras Hall.

I must confess that the evidence has scemed to me inconclusive, as the specimen might have been an Actinoceras with the siphuncle near one side. Nor is the photographic reproduction given by Crick entirely satisfying, as it leaves many of the characters of the specimen in an indeterminable state, especially the nature of the camerse. A specimen in the Survey collection showing a similarly wide siphuncle and short cameræ, appeared to be related to the form described hy Crick, but this too I was at first disposed to refer to Actinoceras, as aside from the proportions, it seemed to show no very decisive characters differentiating it from other species of that genus which occur in these rocks, except the empty camere, a feature not found in any other species of Actinoceras in the Ordovician rocks of China. This led to a more careful study of the specimen, with the result that several of the septa were found to show the true Gonioceras curvatures. This settles the question as to the presence of the genus Gonioceras in the Ordovician of north China, and it lends a strong measure of probability to the correctness of the interpretation suggested by Crick, and to him must be given the credit for the discovery of this unique organism in China, a discovery of very great importance, as already pointed out by Ruedemann. For, as this genus is otherwise only known in the Chazy, Black River and early Trenton of eastern and central North America, extending to the base of the Stones River group in Tennessee, it places beyond the question of a doubt the former intimate 
marine connection of these two districts, a connection which nearly all of the other fossils so far obtained from the highest Ordovician rocks of north China have persistently pointed to.*

The specimen of Gonioceras described below, came from Seng Chuang in NingYang, province of Shantung, about $190 \mathrm{~km}$. (315 li) southwest of the locality where Mr. Couling's specimens (described by Crick) were found. So far then this genus is only known from Shantung but its discovery in Chihli province may now be looked forward to with confidence.

\section{Gonioceras shantungense Grabau (sp, nov.)}

Plate VIII, figs. 11a, b.

cf. Gonioceras sp. Crick. Geological Magazine, New Series Dec. IV. Vol. X. pl. XXII, fig. B, 1903 .

Form of shell unknown, but apparently of the usual expanded and thin character of the genus. Siphuncle probably excentric, but the exact position in the shell not known, the only specimen in our possession having apparently been worn before embedding. The siphuncular elements (the nummuli) are apparently uniform or enlarge only very slightly forward. They are $11.5 \mathrm{~mm}$. in greatest diameter in the section shown, which is probably cut a short distance beyond the central plane, no evidence of an endosiphuncle appearing. From the fact that the transverse section shows only about $4 \mathrm{~mm}$. of thickness for the siphuncle, it would appear that, provided it was circular, its diameter was originally about $13 \mathrm{~mm}$. The stereoplasmic filling is distinctly actinoceran consisting of rosettes of obstruction rings at the septal necks. At this point the siphuncle contracts to $7.5 \mathrm{~mm}$.

The septa average $2.4 \mathrm{~mm}$. apart, and the cameræ are without stereoplasmic filling except for a very slight thickening at the points where they become free from the

* I may add that my reticence in accepting as conclusive the argument for the occurrence of this genus in the Chinese rocks, was to a large extent influenced by $\mathrm{my}$ hope of finding just \&uch satisfactory evidence of the former intimate connection of northern China and eastern North America, as this occurrence affords, for as the study of the Chinese material progressed, this connection became more and more evident, Still I was loth to accept any but the most conclusive evidence, and the discovery of an undoubted specimen of Gonioceras, coming as it did towards the close of these studies, affords therefore unparalleled satisfaction. I may further note, that a specimen of Columnaria, which I am unable to distinguisl from the common $C$. halli of the American Black River beds has come into my hands. This epecimen, found in the collection of Yenching college (Peking) is said to have come from the hills of eastern Szechuan, north of the Yangtse, and west of the sonthernmost locality (in Hupeh) in which Actinoceras has been found. As long however as the shadow of a possibility remains, that in the vicissitudes which a student collection suffers, an American specimen might have been substituted for the original specimen from central Clina, I am unwilling to include it in this memoir. A further note regarding it will, however, be published in the Bulletin of the Survey. 
siphuncle. Most of the septa are broken off a short distance beyond the siphuncle, but near the base of the section a few of them are found to continue outward, and although they are somewhat broken they show the undoubted rather sharp return curve, so characteristic of this genus. This is shown in the illustration.

In its gencral form and character this species comes nearer to Goninceras chaziense Ruedemann* from the middle Chazy limestone of Chazy N.Y. on Lake Champlain (U. S. A.) then to either of the other two known species from the higher rocks. The siphuncle of the Chazy species is however only $7 \mathrm{~mm}$. in diameter while the distance between the septa averages $2 \mathrm{~mm}$. The greatest width of that shell is a little over 70 $\mathrm{mm}$. that of our species can not be ascertained. In the Chazy species each septum rises within the body of the conch to the height of five cameras, before it forms the characteristic return curve. In our species this character is much less pronounced, the septum scarcely rising to the height of one and a half camera, and the angle of recurvature is rather chasp, while beyond it the septum continues with a gentle forward concavity. It is at or near the angle of recurvature, that most of the septa are broken away.

Horizon and Locality: The single known specimen came from Seng Chuang, (Shen Tsun) Ning-Yang, province of Shantung, where it was collected by Dr. V. K. Ting. The specimens described by Crick, which may belong to this species (though the fact that one of his specimens was $25 \mathrm{~cm}$. in length, makes this doubtful) were collected by Mr. Samuel Couling near Chingchow Fu, Kiaochow, also in the province of Shantung.

Class CRUSTACEA Lamarck Sub-Class TRILOBITA Walch Order Opisthoparia Beecher Family ASAPHIDAE Burmeister .

Genus ASAPHUS Brongniart

Asaphus boehmi Lorenz

Plate I, figs. 8, 9.

1906 Asaphus boehmi Lorenz. Beiträge zur Geologie und Palæontologie von Ostasien, Ir. p $84, \mathrm{pl}$. XVII, figs. $4,5 \mathrm{a}, 5 \mathrm{~b}$. 
Original Description:

"Wir haben hier zweifellos einen echten Asaphus und zwar die engere Gattung Asaphus vor uns, deren Grenzen Fr. Schmidt* umschrieben hat. Die Unterabteilungen Salters ** konnten keine passende Anwendung finden."

"Kopfschild ist nur in einem Exemplar vertreten. Glabella nach vorn birnenförmig verbreitert. An Furchen ist nur eine sehr tiefe und breite Basalfurche an der hinteren Glabella vorhanden. Hinter der tiefen Basalfurche ist eine schmale, flache Occipitalfurche entwickelt. Der zwischen den beiden Furchen gelegene Rand trägt einen kleinen Höcker. Die Augen liegen weit hinten. Durch den charakteristischen Verlauf der Gesichtsnaht bekommen die Wangen das Aussehen von zwei flügelartigen Lappen, die hinten zu beiden Seiten der Glabella liegen. Die Gesichtsnähte laufen scheinbar vor der Glabella zusammen. Das Pygidium ist in seiner Gesamtform parabolisch. Ein breiter Randsaum bildet die Umrandung. Die Segmentièrung ist zahlreich, aber schwer sichtbar. Auf den Seitenteilen sind die Pleuren mit unbewaffnetem Auge kaum zu erkennen. Die Rachis hat eine clarakteristische Form. In ihrem hinteren Verlauf gleichmässig schmal, verbreitert sie sich unvermittelt nach vorn. Die Schale ist geädert. Diese Skulptur entspricht wohl den Terrassenlinien von Fr. Schmidt.

"Ich nenne diese Art nach meinem früheren Lehrer, Herrn Prof. Dr. Georg Böhm an der Universität zu Freiburg i./Br.

"Ich sammelte diese Fossilien in einem gelblichen mergligen Kalkschiefer hart am Wege etwas unter dem Gipfel des Hoschan. Das Alter der Schichten ergibt sich durch das Auftreten obiger Trilobitengattung als zweifellos untersilurisch.***

Two small fragmentary pygidia from Chaokouchuang are referable to this species. The axis is strongly elevated and broadens rather rapidly in the anterior portion; the sides are concave. The anterior ring is narrow and continued as a distinct but narrow ridge along the anterior border of the limb on either side of the axis. The other axial rings, of which 5 are partly preserved on one specimen, are about twice as wide as the first, separated by narrow and shallow transverse furrows, their shallowness making the anuulation of the axis scarcely visible except in certain positions. Lateral furrows of axis rather pronounced. Limb smooth except for the anterior bounding ridge; doublure of margin rather broad, marked by irregular longitudinal lines. Entire surface of pygidium finely punctate. 
Measurements: The following are the measurements of the pygidia described and of that figured by Lorenz.

\begin{tabular}{|c|c|c|c|}
\hline & \multicolumn{2}{|c|}{$\begin{array}{c}\text { Chihli } \\
\text { Specimens described }\end{array}$} & $\begin{array}{l}\text { Shantung } \\
\text { Lorenz type }\end{array}$ \\
\hline & $a$ & $\mathrm{~b}$ & $\mathrm{c}$ \\
\hline Anterior width of pygidium & $12.5 \mathrm{~mm}$. & 12. $\mathrm{mm}$. & 16. $\mathrm{mm}$. \\
\hline Width of axis at anterior end & $3.3 \quad$, & $3.5 \quad$, & 5. , , , \\
\hline Greatest length of pygidium & $? 8$. & 8. & 11.5, \\
\hline Length of axis & $? 6$. & 7. & 8. \\
\hline
\end{tabular}

Horizon and Locality: In the Machiakou limestone of Chaokouchuang in the Kaiping basin, Chihli province (Survey expedition coll.). Lorenz's type came from essentially the same horizon near the summit of the Hoshan in Shantung.

\section{Asaphus sp.}

There is at least one other species of Asaphus (or Isotelus?) in the collections from the Kaiping basin, but the material is too fragmentary for description. It indicates, however, a much larger species than A. boehmi. Asaphus? of an indeterminate species has also been recorded by Weller in these rocks near Tsai-Kia-Chuang in Shantung. Other species are found in south China, but these are excluded from the present discussion. 


\section{BIBLIOGRAPHY.}

Barrande, J. Systèrne Silurien du centre de la Bohême. Praha.

Biedfrmann, W. 1901. Untersuchungen über Bau und Entstehung der Molluskenschalen. Jenaische Zeitschrift für Naturwissenschaft. Bd. 36, pp. 1-164, Taf. I-VI.

Bilitiga, E. 1865. Palæozoic Fossils, Vol. I, Geological Survey of Canada.

Brown, J. Cogigrv. 1913. Contributions to the Geology of the province of Yunnan in western China, III. Notes on the Stratigraphy of the Ordovician and Silurian beds of western Yunnan. Records Geological Survey of India Vol. XLIII pt. 4, pp. 327-334.

Clarke, John M. 1897. The Lower Silurian Cephalopoda of Minnesota. Minnesota Geological Survey. Palæontology. Pt. II, pp. 761-812 plates 48-54.

Crick, G. R. 1903. Notes on some specimens of straight-shelled Nautiloidea collected by the Rev. Samuel Couling, M.A. Ching-Chow-Fu, Kiaochow, North China. Geological Magazine, New Series, Decade IV. Vol. X. pp. 481-485, pl. XXII.

Davidson, Thomas. 1865-1870. British Silurian Brachiopoda. Palæontographical Society. Monographs vols. XIX, XX, XXII, XXIV.

Ford, Arthur H. 1888. Catalogue of the Fossil Cephalopoda in the British Museum. Part I Nautiloidea.. London.

Frech, F. 1895. Ueber Palæozoische Faunen aus Asien und North Afrika. Neues Jahrbuch für Mineralogie Geologie und Paläontologie, 1895, Bd. II.*

Frech, F. 1911. Das Silur von China. In Richthofen, China. Vol. V, pp. 1-17, plates I-IV.

Grabau, A. W. \& Shmer, H. W. 1909. North American Index Fossils, Invertebrates. Vol. I. (Protozoa to Gastropoda), New-York.

Grabau, A. W. \& Shmer, H. W. 1910. Ibid. Vol. II (Conularida to Echinoidea). New York.

Grabau, A. W. 1916. Comparison of American and European Lower Ordovicic. Formations. Bulletin Geological Society of America. Vol. 27, pp. 555-622.

HaLl, J. 1847. Palæontology of New York. Vol. I. New York State Geolosival Survey.

-Hinde, J. G. 1889. On Archæocyathus, (etc.) from Cambrian Strata of North America, Spain, Sardinia, and Scotland. Quarterly Journal of the Geological Society of London, Vol. XIJV, pp. 125-148, pl. V. 
Vol $I$.

Kayser, E. 1883. Mittel-und Obersilurische Versteinerungen aus dem Gebirgsland von Tshau-Tien (China). In Richthofen China Vol. IV. article 3. pp. 37-49, plates III \& IV.

Lorenz, Tir. 1906. Beiträge zur Geologie und Palæontologic von Ostasien, unter lesonderer Berücksichtigung der Provinz Schantung in China. II Palæontologischer T'eil, mit 3 Tafeln u. 55 Figuren im Text. (pp. 53-108 pls. IV-VI). Aus Zeitschrift der Deutschen Geologischen Gesellschaft. 1906.

Mansuy, H. 1912. Paléontologie, in Étude Géologique du Yun-nan Oriental par J. Deprat et H. Mansuy, $2^{\ominus}$ Partie. Memoirs du Service Géologique de l'Indochine. Volume I. Fascicule II, Hanoi-Haiphong, 1912.

Marteli, 1901. Fossili del Siluriano inferiore dello Schensi. Bolletin della Soc. Geol. Ital. 1901.*

Pendizzari, 1913. Fossili Palæozoici antichi dello Scensi (Cina). Rivista Italiana di Paleontologia. Vol. XIX. 1913.*

Richthofen, F. von. 1883. 1911. China. Vols. IV \& V. Berlin.

Roemer, Ferdinand. 1876. Lethæa geognostica, oder Beschreibung und Abbildung der für dic Gebirgs-Formationen bezeichnendsten Versteinerungen, I Theil, Lethæa palæozoica, plates.

Roemer, F. \& Frech, F. 1880-1897 ibid. Text.

Ruedemann, R. 1904. Structure of some primitive cephalopods. Annual Report New York State Palæontologist 1903. N.Y. State Museum Bulletin 80, pp. 296-384. Pls. 6-13.

Ruedrmann, R. 1906. Cephalopoda of the Beekmantown and Chazy Formations of the Champlain Basin. New York State Museum. Bulletin 90, pp. 393-605, 38 plates.

Stermana, G., 1889. Ueber Schalen- und Kalksteinbildung. Bericht der Naturforschenden Gesellschaft zu Freiburg. Vol. 4.

Stempeld, Walter, 1900. Ueder die Bildungsweise und das Wachstum der Muschelund Schneckenschalen. Biologisches Centralblatt, Band XX, pp. 595-606; 637$644 ; 665-680 ; 698-703$; and 731-741. (With extensive literature references.)

'Taylor, I. Griffith. 1910. The Archeocyathinæ from the Cambrian of South Australia, with an account of the morphology and affinities of the whole class. Memoirs of the Royal Society of South Australia. Vol. II, pt. 2, pp. 1-188, 16 plates \& text figures. Adelaide. 
(I) 98

Ulrich, E. O. \& Scofield. 1908. The Lower Silurian Gastropoda of Minnesota. Minnesota Geological Survey, Palæontology Part. II.

Verneuil, E. DE. 1845. Palæontologie (of Russia) in Murchison, de Verneuil and Kayserling, Geology of Russia. Vol. II.

Weller, Stuart. 1913. A report on Ordovician Fossils collected in Eastern Asia in 1903-04. In Willis, Research in China, Vol. III, pp. 279-294. plates 25, 26.

Wincheli, N. H. \& Schuchert Charies. 1893. The Lower Silurian Brachiopoda of Minnesota. Minnesota Geological Survey. Palæontology, Part III. No. 1.

YABE, H. \& Hayasaka, I. 1920. Palæontology of Southern China. Geographical Research in China 1911-1916, Reports, pp. 1-221. Atlas of 28 plates. Tokyo Geographical Society. 
List of Chinese Localities referred to, arranged Alphabetically under Provinces. (See Map Fig. 20.)

Chihli 直隸

$\begin{array}{ll}\text { Chao Kou Chuang } & \text { 趙各莊 } \\ \text { Ching Hsing } & \text { 井陘 } \\ \text { Huo Lu } & \text { 獲鹿 } \\ \text { Ku Shan } & \text { 鼓山 } \\ \text { Liang Chia Shan } & \text { 亮家山 } \\ \text { Ma Chia Kou } & \text { 馬家筷 } \\ \text { Pei Lin Tze } & \text { 北林子 } \\ \text { Shih T'ou Chiang } & \text { 石頭江 } \\ \text { Tang Shan } & \text { 唐山 } \\ \text { Yeh Li } & \text { 冶里 }\end{array}$

Manchuria 東三省

Hsiau Sörr

小市

Shantung 山東

Chang Ching

長 毒

Ching Chow $\mathrm{Fu}$

青 州 府

Ching Chuang

青庄

Ho Shan

胡山

Lin Ch'êng

隔城

Mon Yin

蒙陰

Ning Yang

裪陽

Shen Tsun (Seng Chuang) 沈 村

Tai An

泰安

Tsai Kia Chuang

蔡家莊

Wên Nan

淡 南

Honan 河 南

Shê Hsien

涉 䅫

Hupeh 湖 北

$\begin{array}{ll}\text { Hsing Shan Hsien } & \text { 興山䅫 } \\ \text { Hu Chi } & \text { 戶哚 } \\ \text { No Lu Ping } & \\ \text { Pan Tze Ya } & \text { 播子埡 }\end{array}$




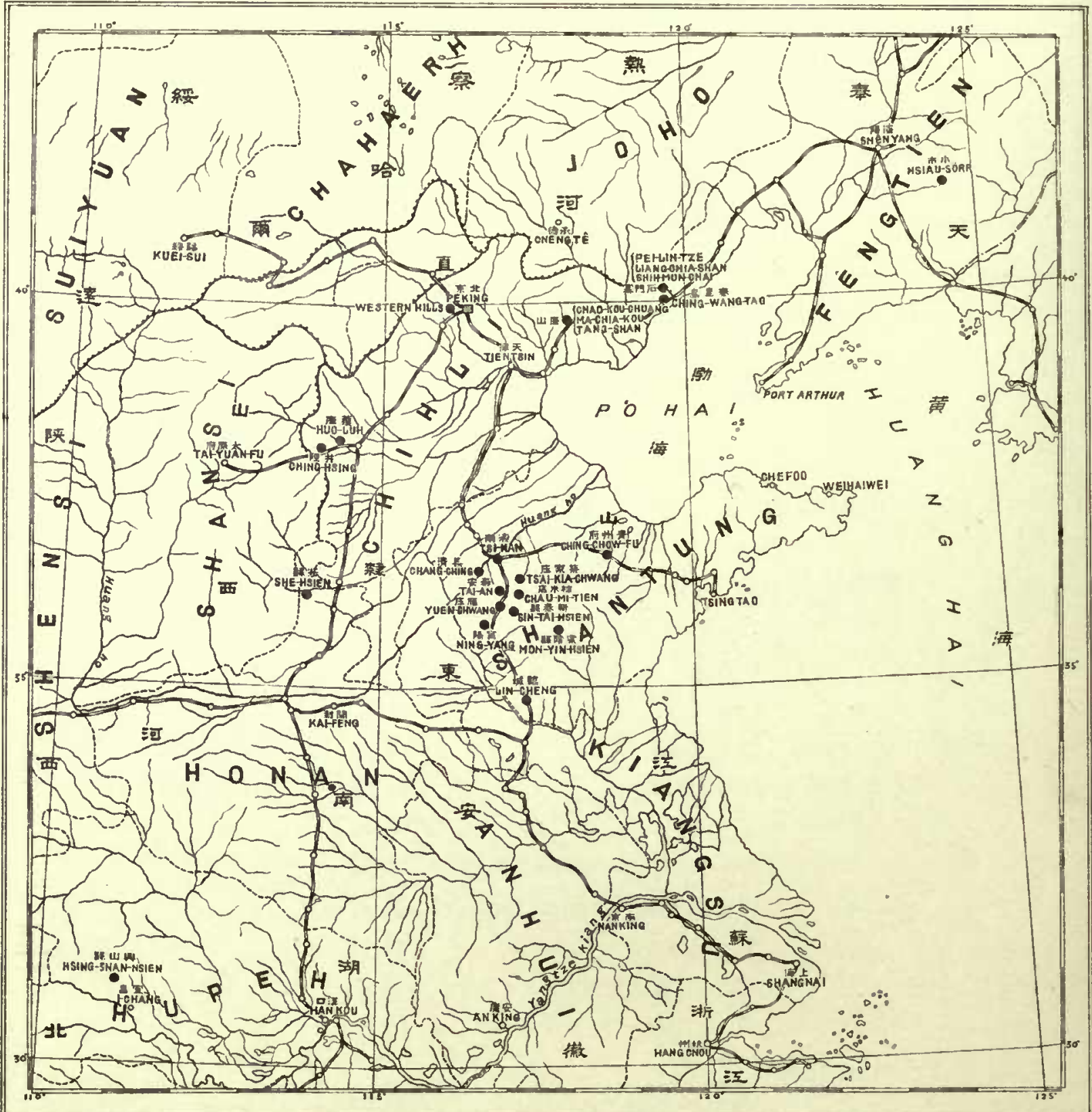

Boundaries of Provinces Railroads and Stations Great Wall - Ordovician Localities o Other important Cities

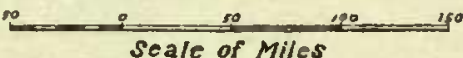

Fig. 20. Map of North-eastern China, showing the localities where Ordovician fossils have leen found. 


\section{EXPLANATION OF}

PLATE I

(I) 101 


\section{PLATE I.}

Lower Ondovician Anthozoa (1-S) and Cephalopoda (10); Peilintze Limestone. Upper Ordovician Brachiopoda Pelerypoda and Trilobita; Machiakou Limestone.

\section{Drawings by K. C. Liu (劉光城) Pleotographs by T. I. Loo（慮䒬落）}

Fig. 1. Artwrocyathus chihliense Grabau............................................p. 12

1t. Mold of part of interior of caliculum with weathered section near the upper edge of the caliculum. Natural size.

1b. Photograph of partial section of caliculum $50 \mathrm{~mm}$. below preceding; nearly watural size. The right and left sides are reversed with reference to fig. 1a. Lower Ordovician Peilintze limestone, Shih-Mun-Chai, Chihli. (Coll. F. F. Mathieu, Cotype G. S. Ch. Cat. No. 75).

Fig. 2. Arehrocyathus chihlicnse Grabau

Photograph of polished section of a compressed caliculum same horizon and locality.

Natural size. (Cotype Coll. F. F. Mathieu, G. S. Ch. Cat. No. 76).

Fig. 3. Arehxocyathus chilhiense Grabau....

3a. Photograph of thin section of a nearly circular caliculum. Natural sizc.

3b. A small portion photographically enlarged $\times 10$; same horizon and locality. (Cotype Coll. F. F. Mathieu, G. S. Ch. Cat. No. 98).

Fig. 4. Orthis calligramma rar. orthambonites ron Buch (de Verneuil) p. 15 $4 \mathrm{a}$ brachial-, $4 \mathrm{~b}$ pedicle-, $4 \mathrm{c}$ side-view of a small fragmentary specimen $\times 3$; Machiakou limestone, Chao-Kou-Chuang, Chihli province. (G. S. Ch. Cat. No. 94).

Fig. 5. Orthis calligramma var. orthambonites von Buch (de Verneuil) 5i pedicle-, 5́b brachinl-,5c lateral-,5d frontnl-views of a larger, somewhat distorted and more nearly complete specimen. $\times 2$. (In $4 d$ the upper valve is the brachial, which appears as the deeper of the two because of the position in which the specimen is drawn). Same horizon and locality. (G. S. Ch. Cat. No. 93).

Fig. 6. Strophomena ef. incurvata (Shepard) p. 17

Part of pedicle valre, with outline restored $\times 3$.

Upper Qrdovician, Machiakou limestone, Chao-Kon-Chuang. (G. S. Ch. Cat. No. 109).

Fig. 7. Ctenodonta symmetrica Grabau............................................. 1

Interior view of a right valve, showing the hinge line, (with the teeth somewhat too clearly represented), the muscular scars and anterior muscular ridge. The ventral margin is imperfect. Enlarged twice. Machiakou limestone, Tangshan, Chihli. (Holotype G. B. Barbour Coll. G. S. Ch. Cat. No. 51).

Fig. S. Asaphlus bohmi Lorenz.

An imperfect pygidium, enlarged $\times 2$. showing broad ringed axis, and concare marginal rim. Machiakou limestone, Chao-Kou-Chuang, Chillli. (G. S. Ch. Cat. No.92).

Fig. 9. Asphus brhmi Lorenz.

Another prgidium from the same horizon and locality as the preceding but exfoliated, showing narrow axis, $\times 2$. (G. S. Ch. Cat. No. 110).

Fig. 10. Chillioceras nathani Grabau.

Apertural view of the siphuncle shown in the right hand figure of Plate $V$. to show the main and lateral alreoli. The specimen is slightly crushed, and is reathered. Lower Ordovician Peilintze limestone, Shih-Mun-Chai region, Chihli. (G. S. Ch. Cat. No. 111). 


\section{PALEONTOLOGIA SINICA}

Grabau: Ordovician Fossils of N. China

Pl.I.
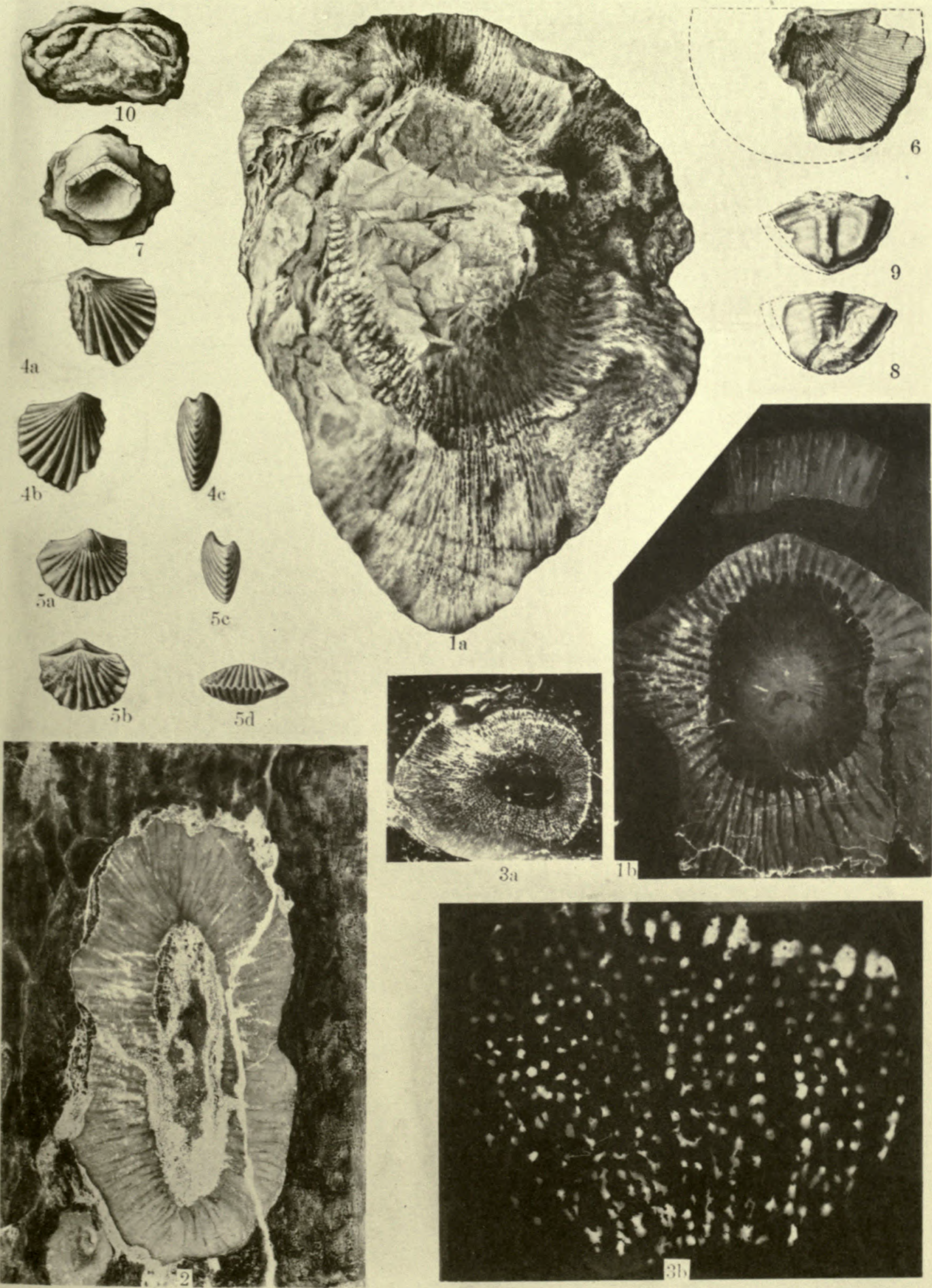

3a
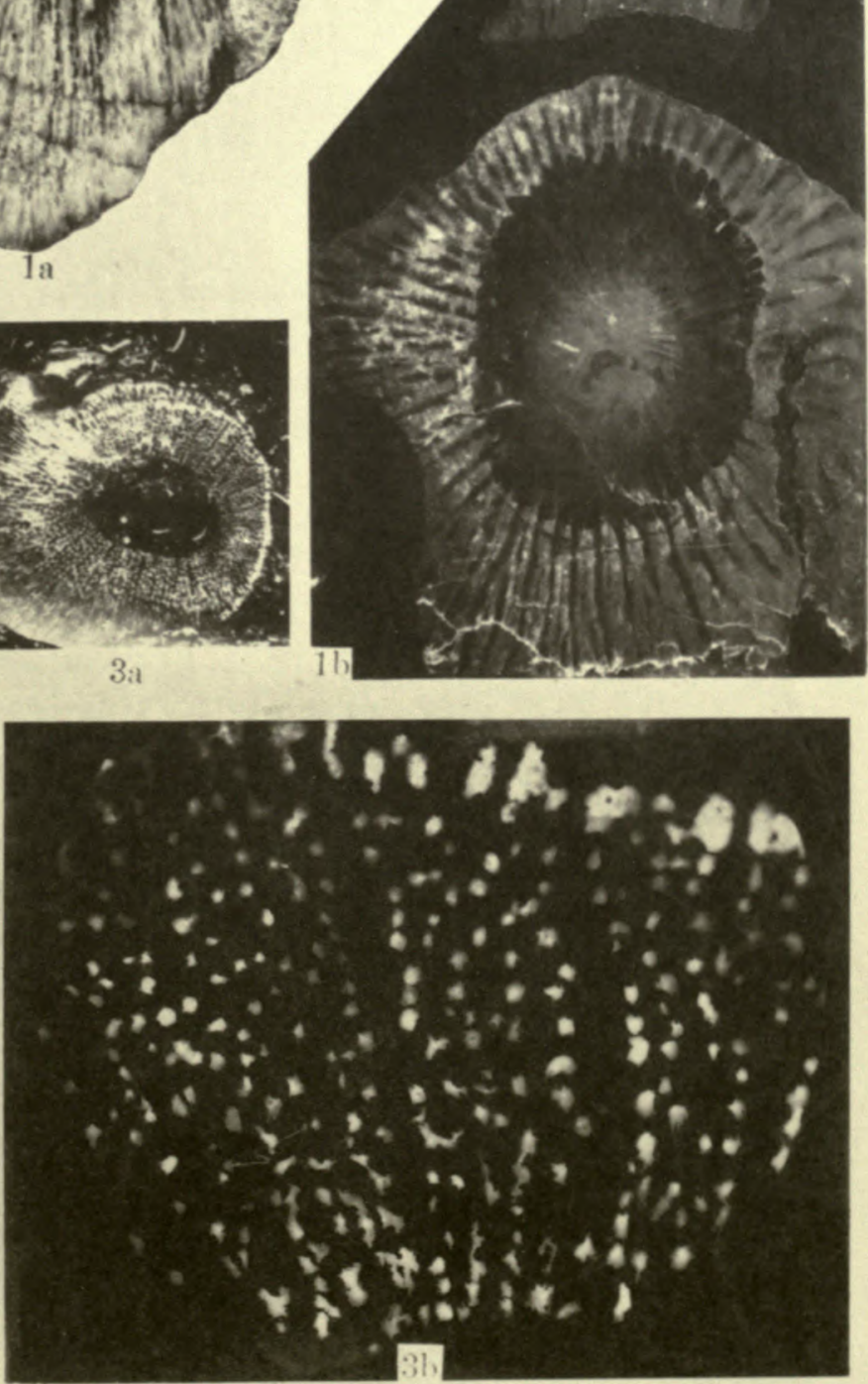

EXPLANATION OF

PLATE II

(I) 103 


\section{PLATE II.}

Ordovician Gastropoda and Cephalopoda (11-13); Lower Ordovician: Pcilintze und Liangchiashan Limestones; Upper Oidorician: Machiakou Limestone.

\section{Drawings by K. C. Liu (劉光城)}

Fig. 1. Ophildn plant Grabau...................................................... 20

Adult specimen, natural size, embedded in rock (which is not fully represented). The surface is weathered. Liangchiashan limestone (Lower Ordovician) LiangChia-Shan, Chihli, Coll. F. F. Mathien. (Cotype G. S. Ch. Cat. No. 84).

Fig. 2. Ophilcta plana (imbau...

Young shell, top (2a) and side (2b) riews. Natural size. The surface scolpture is only apparent, and due to weathering. Liangchiashan limestone (Lower Ordorician) Liang-Chia-Shan, Chihli. Coll. I. F. Mathieu. (Cotype (i. S. Ch. Cat. No. 83 ).

Fig. 3. Ophilete squamose Grabau

$3 a$ Top view of a small specimen with lax final whorl, enlarged twice. $3 \mathrm{~b}$ side view of the same, $\times 2$. Peilintze linestone, Pei-Lin-Tze, Shih-Mnn-Chai, Chihli. Coll. F. F. Mathieu. (Cotype G. S. Ch. Cat. No. 86).

Fig. 4. Opliteta squamosa Grabau.

Unbilical view of a flagment of the whorls of a young specimen $\times 2$. Peilintze limestone, Pei-Lin-Tze, Chihli. Coll. F. F. Mathien. (Cotype G. S. Ch. Cat. No. 85 ).

Fig. j. Ophilete squamose Grabau....

Natural section of an adult specinen, nutural size. Peilintze limestone, Pei-Lin-Tze, Chibli. Coll. F. F. Mathieu. (Cotype G. S. Ch. Cat. No. 95).

Fig. 6. Oplileta squamosa Grabau

A much weathered section of an adult specimen. Natural size. Peilintze limestone, Pei-Lin-Tze, Chihli, Coll. F. F. Mathieu. (Cotype G. S. Ch. Cat. No. 89).

Fig. 7. Eceyliopterus linshancnsis Grabau............................................ 23

7a Summit view of the holotype natural size. $7 \mathrm{~b}$ Umbilical view of the same, natural size. $7 \mathrm{c}$ Cross-section of the shell to show form of whorls and degree of embracing. Machiakou limestone, Ku-Shan, Hwo-Luh-Hsien, Chihli. (Holotype G. S. Cl. Cat. No. 96).

Fig. 8. Liccyliopterus sinensis (Frech)

Sa-c. Summit, lateral and umbilical views of a characteristic specimen from Nei-Ya-Shan, near Iclıang, Hupeh, South China. (For comparison with $E$. kushanensis.) Sd section of the same to show form of whorls and excessive embracing. Middle? Ordovician. G. Langford Smith Coll. (G. S. Ch. Cat. No. 97).

Fig. 1. Eccyliomphahe tangshanensis Grabau...................................... 24 Worn under surface of the partly exposed holotype. Natural size. Machiakou limestone, Tang-Shan, Chilli. (Holotype G. S. Ch. Cat. No. 6).

Fig. 10. Salpingostome terrilli Grabau....

a top, $b$ side, and $c$ anterior views of the type and only known specimen which is crushed and partly broken. Natural size. (Holotype. G. S. Cl. Cat. No. 32 ).

Fig. 11. Chihlioceras nathani Grabau p. 45

An nblique section through the upper part of the endocone of the specimen fig. 13 on pl. IV. (For location see text fig. 6a-b, p. 46). Peilintze limestone, Shih-MunChai region, Chihli. F. F. Mathieu Coll. (Cotype G. S. Ch. Cat. No, 110). 


\section{PALAEONTOLOGIA SINICA}
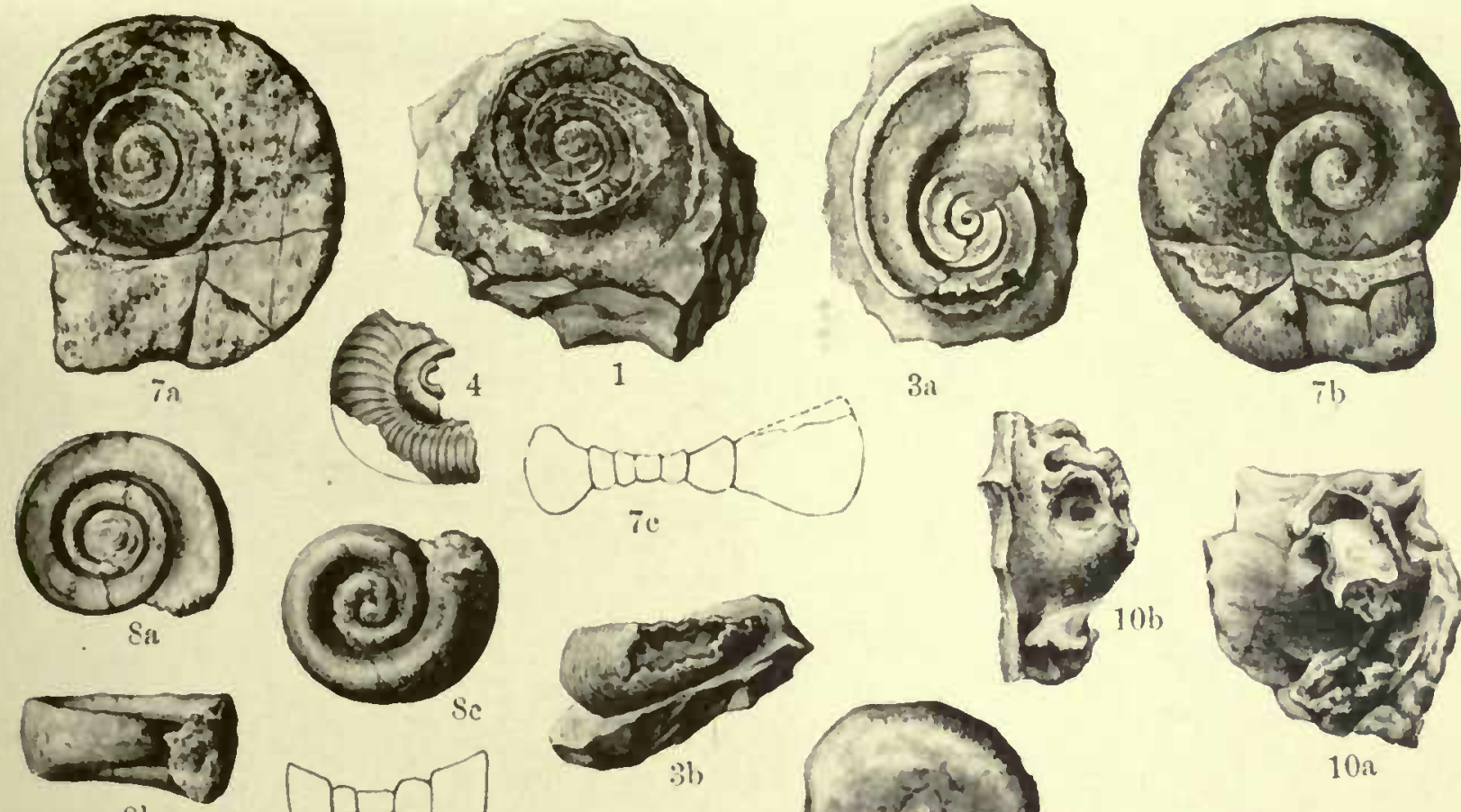

$\mathrm{Sb}$
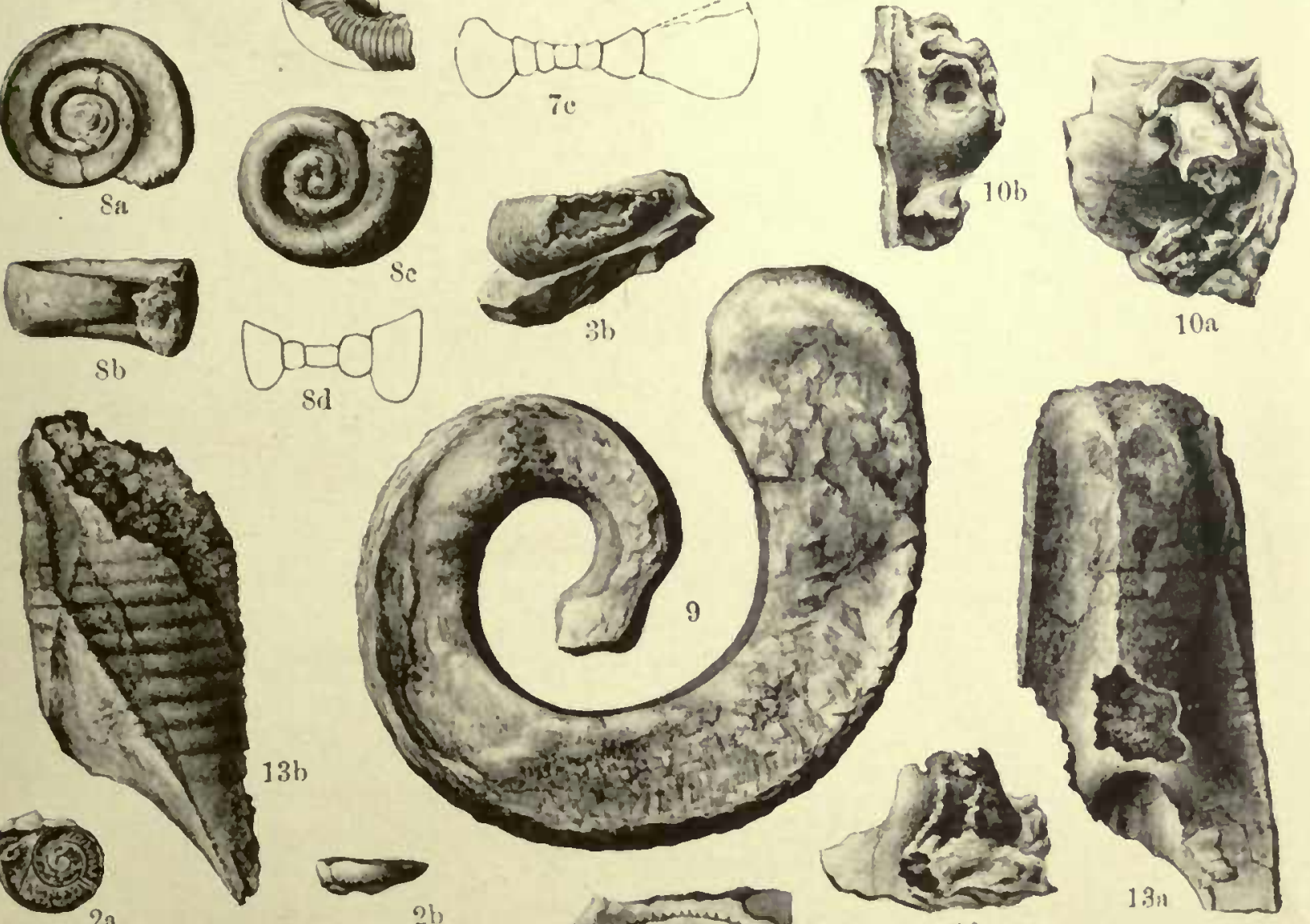

$10 \mathrm{a}$
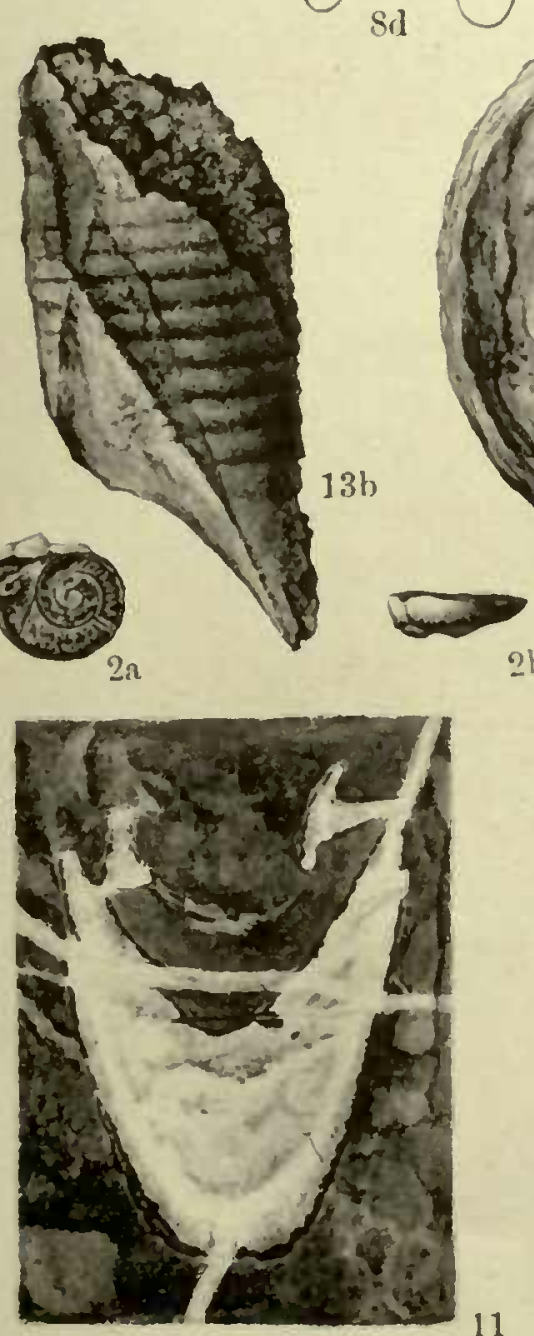

\section{2h}

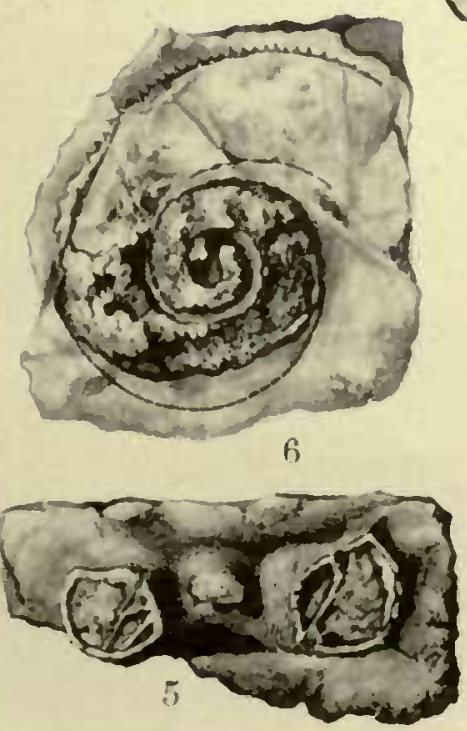

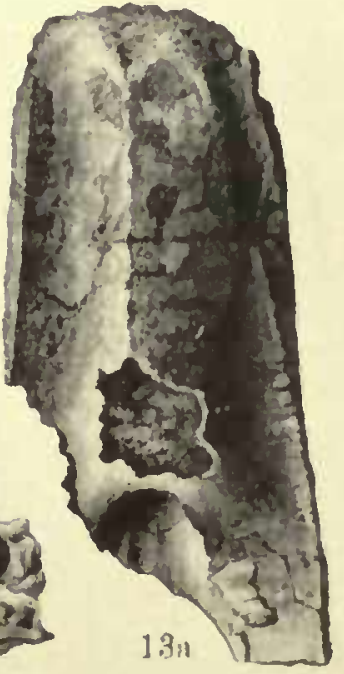

$10 \mathrm{c}$

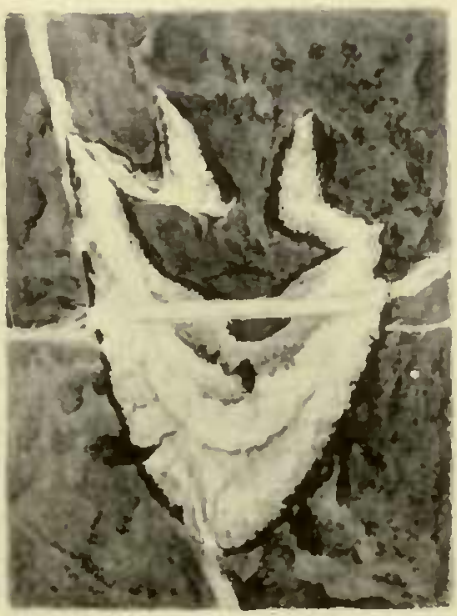



Fig. 12. Chihlioceras nathani Grabau

Another section through the same specimen parallel to the preceding and about $2 \mathrm{~mm}$. farther dorsad. The section is shown on the opposing cut surface of the rock and its position is therefore reversed as here viewed. (For location see text fig. 6, line c-d, also text Figs. 8,9 which show the two sections in the same orientation). Peilintze limestone, Shih-Mun-Chai region, Chihli. F. F. Mathieu Coll. (Cotype G. S. Ch. Cat. No. 111). (See, also, Pls. IV \& V).

Fig. 13. Chihlioceras chingwangtaoense Grabau

13a. View of the type from the upper or dorsal side. Natural size. The specimen is reversed in position as compared with the other figures, to show the median alveolus, and the inner surfaces of the lateral alveoli.. (For restored sections see text figures 14-16).

13b. Side view of the same.

Peilintze limestone, Pei-Lin-Tze, Shih-Mun-Chai region, eastern Chihli. (Holotype, Coll. by F. F. Mathieu, G. S. Ch. (at. No. 113). 

EXPLANATION OF

PLATE III

(I) 107 


\section{PIATTE III.}

Ordovician Gastropoda; Lover Ordovician:-Peilintze and Liangrhiashan Iimestoncs; Upper Ordovician:-Machialion Limestone.

\section{Dravings lin K.C. Liv (劉光城)}

Fig. 1. Lophospira morrisi Grabau.

A nearly complete characteristic specimen, cnlarged twice. Machiakou limestone, 'Tangshan, Chihli. (Cotype, G. S. Ch. Cat. No. 32, collected by Messrs. Morris, Barbour and Terrill).

Fig. 2. Lophospira morrisi Grabau.

2a. View of the spire from an oblique angle, to show the position of the peripheral band, and the growth-lines upon the shoulder $\times 2$.

2b. A portion of the shoulder of the ultimate whorl enlarged six times to show the nature of the peripheral band and the growth lines. Machiakou limestone, Tangshan, Chihli. (Cotype, G. S. Ch. Cat. No. 51; Coll. G. B. Barbour).

Fig. 3. " Lophospira mulchelliformis Grabau.....

Spire of a characteristic specimen $\times 2$, viewed slightly from above, (with resulting foreslortening), to show the peripheral band. Machiakou limestone, Tangshan. Cotype, G. S. Ch. Cat. No. 51 ; Coll. G. B. Barbour).

Fig: 4. Lophospiva mulchelliformis Grabau.

Portion of a spire, lateral view $\times 2$. showing amount of embracing, form, and strong lower carina. Machiakou limestone, Tangshan. (Cotype, G. S. Ch. Cat. No. 41 ; Survey Coll).

Fig. 5. Lophospira trochiformis Grabau.

5a., 5b. opposite sides of the holotype, showing the trochiform spire and strong peripheral carina. $\times 2$. Machiakou limestone, Tangshan. (Holotype, G. S. Ch). Cat. No. 40).

Fig. 6. Lophospiva acuta Grabau. 27 An average specimen, with a small mass of matrix adhering and the basal portion imperfect $\times 2$. Machiakon limestone, Chao-Kou-Chuang. (Cotype, G. S. Ch. Cat. No. 47).

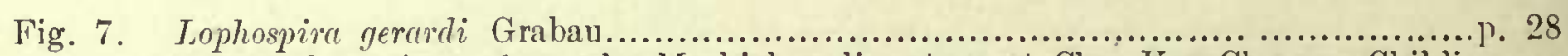
A typical specimen from the Machiakon limestone at Chao-Kon-Chuang, Chihli. Enlarged trice. (Cutype, G. S. Cl. Cat. No. 44).

Fig. 8. Lopliospira gerardi rar. laxa Crraban. $2 S$

The Holotype, showing the lax whorls entirely free at the aperture, the strong subsutural ridge and marked concavity of shoulder $\times 2$. Machiakou limestone, Chao-Kon-Cluang. Chilhli. (Holotype, G. S. Ch. Cat. No. 49).

Fig. 9. Lophospira terrasse Grabau.............................................. 29 View of the type, attached to rock, twice natural size. Machiakou limestone, Tangshan, Chihli. (Holotype, G. S. Cl. Cat. No. 33).

Fig. 10. Lophospira obscura Grabau. The type specimen, embedded in rock and partly worn so as to show the internal mold $\times 2$. Machiakon limestone. Tangshan, Chilıli. (G. S. Ch. Cat. No. 37).

Fig. 11. Pagodispira derwiduii Grabau. p. 31 The type spccimen, twice enlarged. The aperture is restored. Machiakon limestone, Chao-Kou-Chuang, Chihli. (Holotype, G. S. Ch. Cat. No. 45). 
PALIEONTOLOGIA SINICA

Grabau: Ordovician Fossils of N. China

P1.11I.

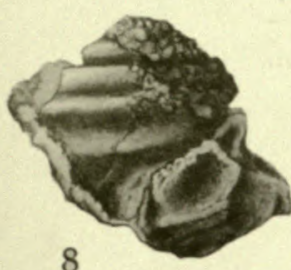

8

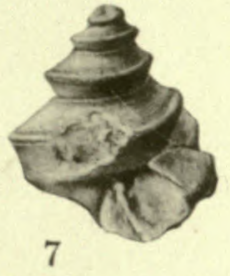

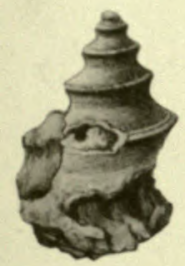

3
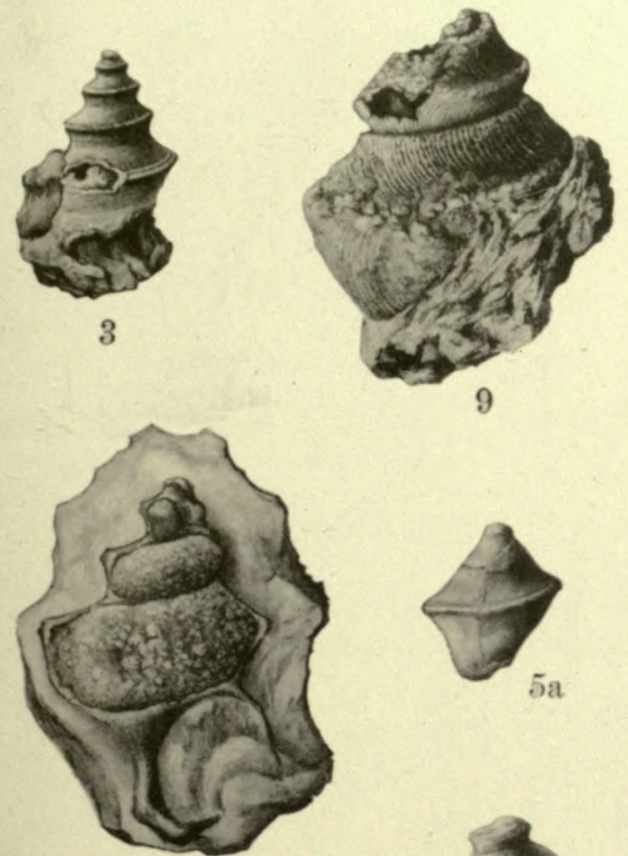

10
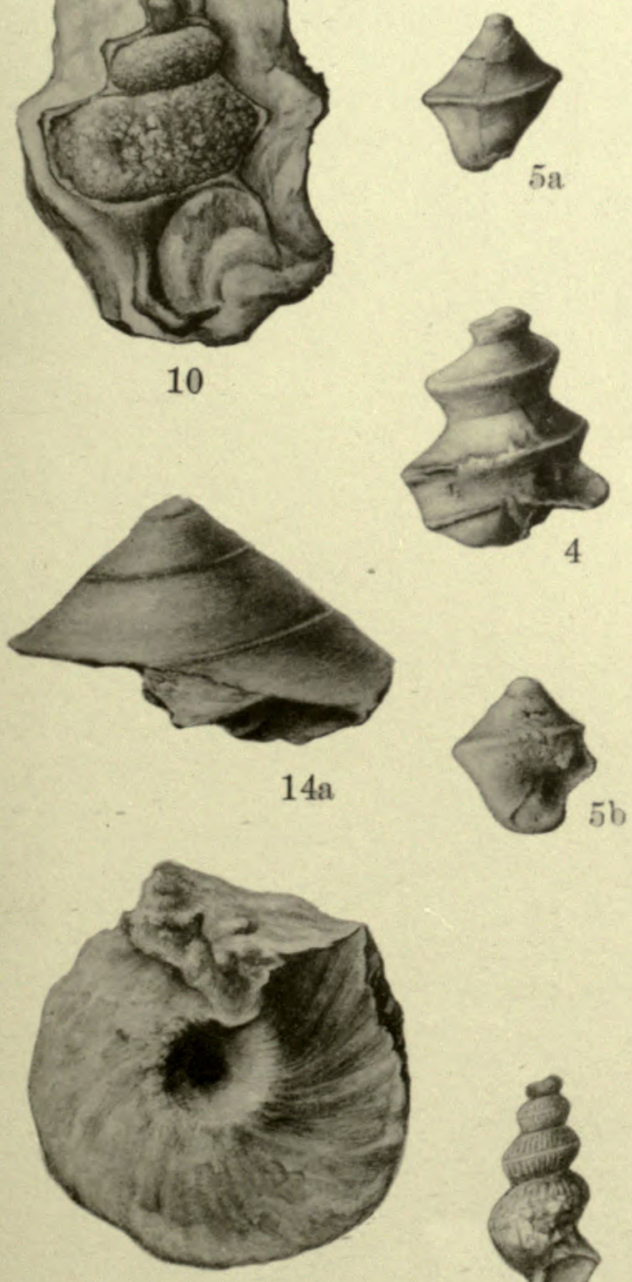

$14 \mathrm{~b}$

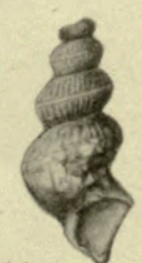

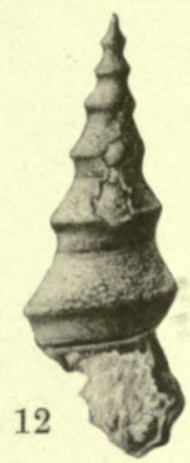
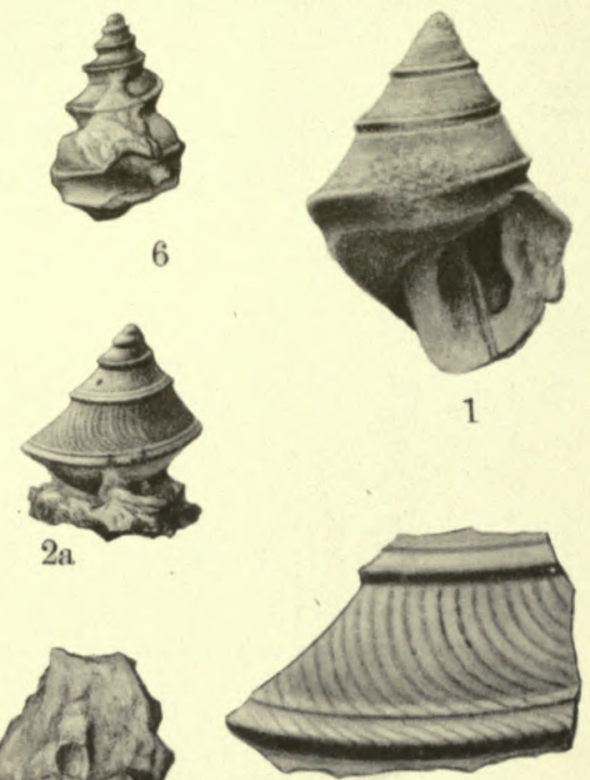

$2 \mathrm{~b}$
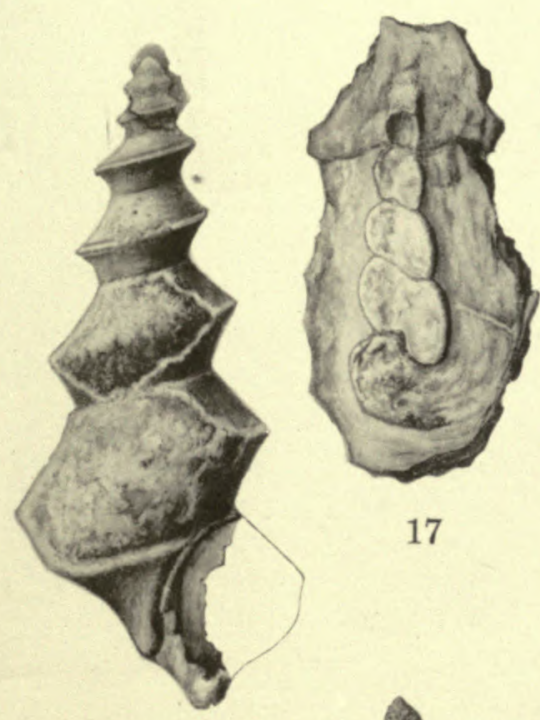

17

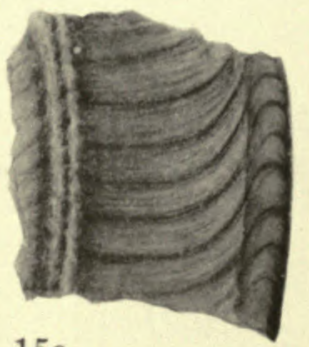

$15 \mathrm{e}$
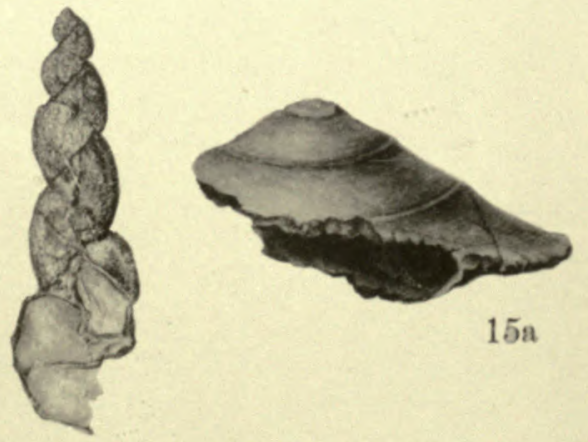

$15 \mathrm{a}$
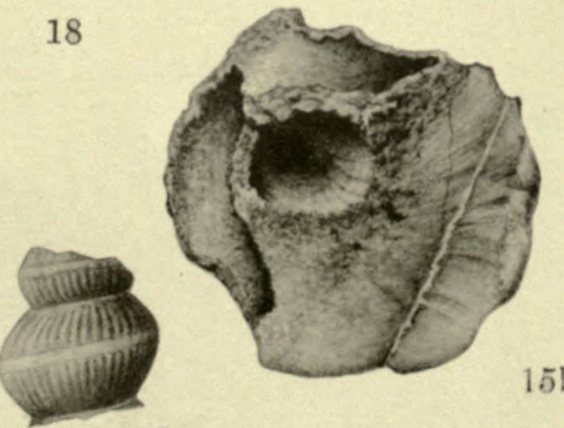

Fig. 12. Pagodispira dorothea Grabau. .p. 32 The type specimen, twice enlarged. Machiakou limestone, Tangshan, Chibli. (Holotype, Coll. by Geo. B. Barbour, G. S. Ch. Cat. No. 50).

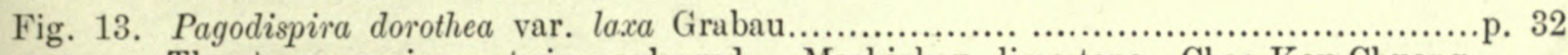
The type specimen twice enlarged. Machiakou limestone, Chao-Kou-Chuang. (Holotype, G. S. Ch. Cat. No. 13).

Fig. 14. Liospira barbouri Grabau. p. 33

14a. Side view of a nearly perfect high-spired form $\times 2$.

14b. Umbilical view of same. $\times 2$. Machiakou limestone, Tangshan, Chihli. (Cotype, Coll. by G. B. Barbour. G. S. Ch. Cat. No. 42).

Fig. 15. Licspira barbouri Grabau p. 33

15a. Side view of an imperfert low-spired shell. $\times 2$.

$15 \mathrm{~b}$. Umbilical view of same $\times 2$.

15c. Enlargement of part of the final whorl to show lines of growth, peripheral band, and marginal notch. $\times$ 4. Machiakou limestone, Tangshan, Chihli. (Cotype, Survey Collection G. S. Ch. Cat. No. 43).

Fig. 16. Hormotoma doquieri Grabau....

16a. The type specimen, enlarged four times.

16b. Two of the whorls still farther enlarged. $(\times 8)$.

Liangchiashan limestone Shih-Mun-Chai region, eastern Chilli. (Holotype, Coll. F. F. Mathieu G. S. Ch. Cat. No, 99).

Fig. 17. Fusispira sp..

A natural section in the rock; natural size. Peilintze limestone, Shih-Mun-Chai, eastern Chihli. Coll. F. F. Mathieu. (G. S. Ch. Cat. No, 90). (This section is weathered to such an extent, that the back of the whorls is shown beyond the umbilicus, giving the shell a sinistral appearance).

Fig. 18. Fusispira sp

A natural section in rock; natural size. Peilintze limestone, Shih-Mun-Chai, eastern Chihli, Coll. F. F. Mathieu. (G. S. Ch. Cat. No. 89). 

EXPLANATION OF

PLATE IV

(I) 111 


\section{PLATE IV.}

Ordovieian Cephalopoda; Lover Ordovician:-Peilintie, Liangchiashan, and Tehli Lime. stones; Ciprer Ordovician:-Machialiou Limestone.

\section{Drauings by K.C. Liu (劉光城)}

Fig. 1. Proterocameroccras mathicui Grabau.............................................. 36

1a. Lateral view of a weathered specimen showing part of the siphuncle, and several camerse. Natural size.

1b. End vicw of the same specimen showing aperture of endosiphocone. Natural size.

1c. Section of the same showing form and position of siphuncle. Natural size." Peilintze limestone, Shih-Mun-Chai, near Chingwangtao, eastern Chihli. (Cotype, Coll. by F. F. Mathieu, G. S. Ch. Cat. No. 100).

Fig. 2. Proteroeamcroceras mathieui Grabau. 36

2a. View of a small portion of the shell embedded in rock, showing flattened siphuncle and camera, natural size.

2b. End view of the same, natural size;

2e. A portion of the shell and adjoining part of the siphuncle enlarged to show the relation of the siphnncular funnels to the outer shell on the ventral side. Peilintze limestone, Shih-Mun-Chai, near Chingwangtao, eastem Chihli. (Cotype, Coll. IF. 1.. Mathieu, G. S. Ch. Cat. No. 101).

Fig. 3. Proterocameroceras mathicui Grabau. p. 36

3a. A free siphuncle in three sections. Natural size.

$3 \mathrm{~b} .-3 \mathrm{e}$. End views of the same at points indicated, $\times 2$. Peilintze limestone, ShilIun-Chai, near Chingwangtao, eastern Chihli, (Cotype, F. F. Mathieu Coll., G. S. Ch. Cat. No. 102).

Fig. 4. Cameroceras styliforme Grabau

4a. The siphuncle of a young or apical portion of a shell, showing the rate of tapering and oblique annulations. Enlarged twice.

4b. Enlargement of the broken smaller end of the same specimen showing the flat ventral side, the endosiphocoleon, and an older endosheath with open lumens remaining; $\times 4$. Liangchiashan limestone (Lower Ordovician), Liang-Chia-Shan, Shih-Mun-Chai, eastern Chihli. (Cotype, F. F. Mathieu, G. S. Ch. Cat. No. 103)

Fig. 5. Cameroceras styliforme Grabau

5 a. Ventral view of an older portion of the siphuncle, showing the ventral saddle formed by the septa. Natural size.

5b. Upper, and 5c. lower ends of the fragment enlarged $\times 2$. to show the endosiphocoleon. Liangchiashan limestone, Shih-Mun-Chai, near Chingwangtao eastern Chihli. Lower Ordovician. (Cotype, Coll. F. F. Mathieu, G. S. Ch. Cat. No. 104).

Fig. 6. Cameroceras styliforme Grabau.... p. 39

6a. Lateral view of a silicified fragment of the siphuncle, of a more mature portion than that represented by figs. 4 \& 5 showing portions of the septa adhering $\times 2$.

6b. Upper and 6c. lower ends of the fragment, showing the last endosheath, its continuation in the endosiphocoleon and indications of older sheaths $\times 2$. Liangchinshan limestone, Liang-Chia-Shan Shih-Mun-Chai, near Chingwangtao, enstern Chihli. (Cotype, Coll. F. F. Mathieu, G. S. Ch. Cat. No. 10ذ).

Fig. 7. Succoceras yehliense Grabau... 1. 40

7a. View of the type specimen as exposed on the rock surface. Natumil size. 
PALAEONTOLOGIA SINICA

Grabau: Ordovician Fossils of N. China

P1.IV.
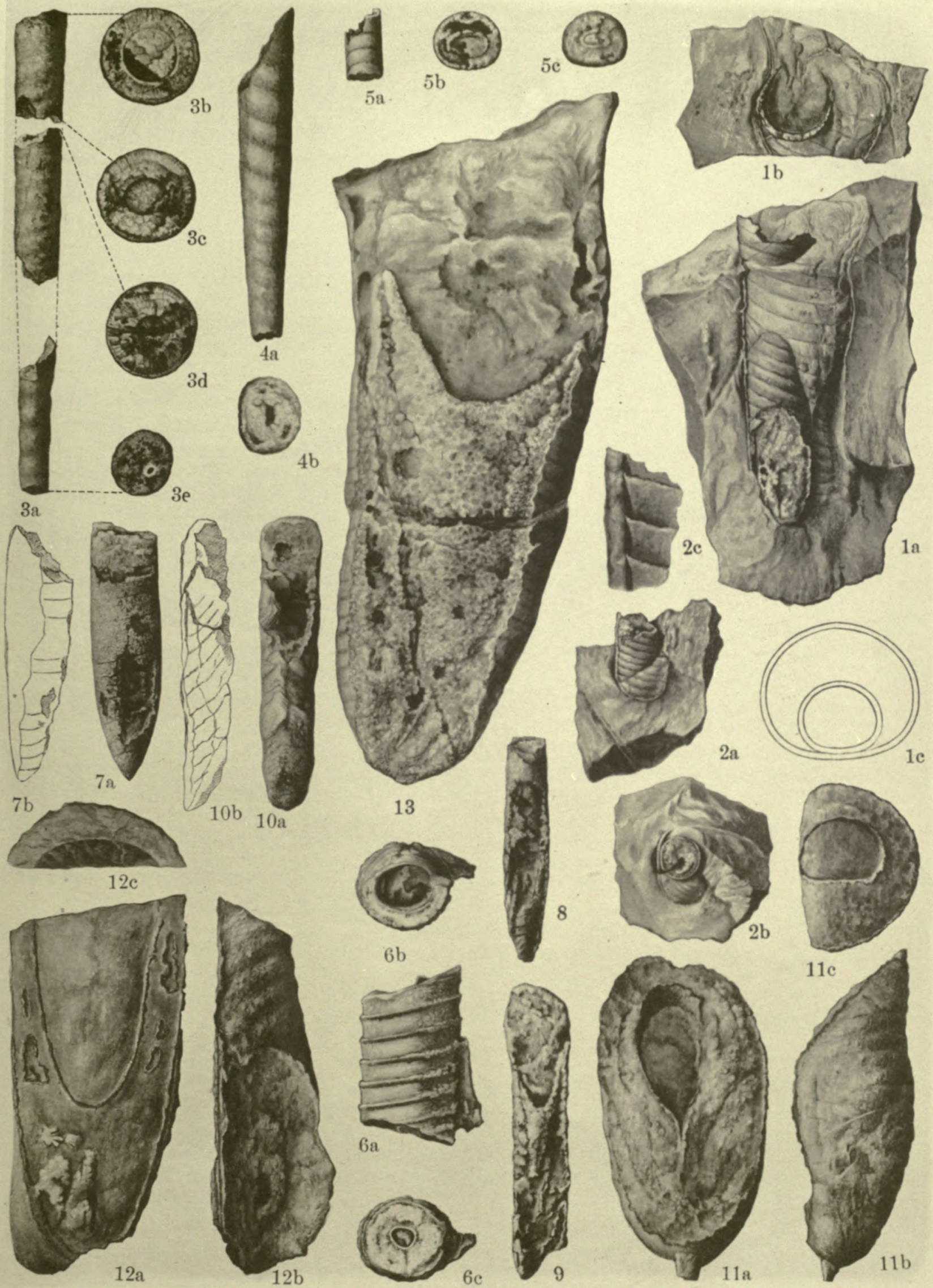

7b. Lateral view of the same, the left hand side is attached to the rock. Natural size. Yehli limestone (Lower Ordovician), Ych-Li, near Ma-Chia-kou, Chibli. (Holotype, Y. C. Sun Coll. G. S. Ch. Cat. No. 24).

Fig. S. Succoccras attenuatum Grabau.....................................................p. 41 Apical portion of the siphuncle, showing rate of tapering. Natural size. Yehli limestone, Yeh-Li, Chihli. (Cotype, Y. C. Sun (oll. G. S. Ch. Cat. No. 20).

Fig. 9. Succoceras altenuatum Grabau............................................... 41

Silicified and partly broken specimen referred to this species, showing the last endosiphosheath, and its excentric position. Natural size. Yehli limestone, YehLi, Chihli. (Cotype, Y. C. Sun Coll. G. S. Ch. Cat. No. 22).

Fig. 10. Vaginoceras tsinanensc Grabau....

10a. Ventral view of siphuncle, showing the strong saddle made by the scptal necks. Natural size.

10b. Lateral view of the same, slowing obliquity of septal necks. The left hand side is attached to the rock. Muchiakou limestone, Tungehan, Chilıli. (Holotype G. S. Ch. Cat. No. 25).

Fig. 11. Piloceras platyventrum Grabau.

11 a. Natural section of the siphuncle, showing the excentric endocone with flattened venter; the endosiphuncle with its terminal projection (this is not as large as here shown, some rock adhering which can not readily be separated), and the crystalline filling. The specimen is either a young form or the endocone extends further apicad in this spccimen than in others (see fig. 12). It is filled with rock matrix enclosing foreign material.

$11 \mathrm{~b}$. Side view of the same showing faint constriction at commencement of annulations. Natural size. (The constriction is slightly over-emphasized owing to the position of the specimen).

11c. Find view of the same, slowing position and form of endocone. Natural size. Liangchiashan limestone, Shih-Mun-Chai region near Chingwangtao, eastern Chihli. (Cotype, F. F. Mathieu, Coll., G. S. Ch. Cat. No. 108).

Fig. 12. Piloceras platycenirum Grabau

12a. Natural section of a siphuncle of a large and older specimen of subcircular crosssection. The section is trausverse to the dorso-ventral diameter but somewhat oblique. The endocone with filling of rock-matrix, and the crystalline filling of the carlier part with indications of older sheaths are sliown. Natural, size.

12b. Side-view of the same, showing subcylindrical outline, with the oblique annulations, which converge in a low broad saddle on the venter (right side). The lower part is fractured, showing complete filling with stereoplasm or organically deposited lime. Older sheaths are indicated in this fracture by dark lines. Natural size.

12c. Eud view (upper) of the fragment, showing the very slight flattening at this stage of the endocone on the ventral side, which is the center of the convex surface (top side of fig. $12 \mathrm{c}$, right side of fiig $12 \mathrm{~b}$ ), as shown by the converging annulations. The thickness of the lime-filled portion of the siphuncle is slightly greater on the venter than on the sides. Liangchiashan limestone, of Liang-Chia-Shan ShihMun-Chai region, near Chingwangtao, eastern Chilnli. (Cotype, F. F. Mathien, Coll. G. S. Ch. Cát. No. 109).

Fig. 13. Chilulioceras nathani Grabau.

Ventrul aspect of a typical specimen partly worn, but showing the endosiphuncle in the lower part. (Scetions of this specimen are shown in figs. 11 \& 12 of pl. II, and a reconstruction in text-figures 2 to $6 \mathrm{pp} .45-46$ ) Peilintze limestone near Chingwangtao, Chillli. (Cotype, F. F. Mathien, Coll., G. S. Ch. Cat. No. 110). (See also Plate V. which shows the upper side of the same slub on the under side of which this specimen occurred). 



\title{
EXPLANATION OF
}

\author{
PLATE V
}

(I) 115 


\section{PLATE V. \\ Lower Ordovician Cephalopods:-Pelintze Limestone.}

Drawings by K. C. Liu (劉光城)

Chilhlioceras nathani Grabau............................................................. 48

A group of three individuals, natural size, all with their upper or dorsal surfaces exposed, and all more or less worn. The rock has also been subject to slight deformations; two fracture lines with slight faulting are shown, the fractures having been filled by calcite reins. The left hand specimen shows only a portion of the blade, but the central one shows a large part of it. The lateral alveoli in this specimen are not preserved, not extending back so far. They are however show1, though in a somewhat crushed condition, in the right hand specimen (see the front view of this on plate I. fig. 10). There is a difference in the rate of tapering of the two most perfect specimens, also in the annulations, and perhaps, though this can not be said with certainty, in the conformation of the endocone. More perfect material may demonstrate, that two distinct species are represented.

On the underside of this rock-mass occurred the specinen of this species figurcd on plate IV fig. 13 , and the sections of which are shown on plate II figs $11 \& 12$. This specimen lay in the same posilion as those here shown so far as the dorso-ventral surfaces were concerned, and therefore, being on the under side of the slab, exposed the ventral side. Its longitudinal axis was however trausverse to those of the specimens here shown. In its detailed cliaracter it corresponds closely to the right-hand specimen of the group on this plate. As it is also the specimen which has furnished, in its sections, the details of internal structure, from which the models (Text figs 2 to 5 ) are constructed, it must be considered the genotype, in case the specimens here shown prove to represent distinct species. The middle one in that case will be a new species.

The outer zone of the middle specimen is formed apparently by a succession of endosheaths which were closely crowded in the apical part of the siphuncle. The inner part, become porous from weathering, represents a solid mass of stereoplasm (organically deposited lime) apparently without further endosheaths until the final one is reached.

Peilintze limestone, Pei-Lin-Tze, Shih-Mun-Chai region near Chingwangtao, castern Chihli. (Cotype, Collected by F. F. Mathien and presented to the collection of the Geological Survey of China, Cat. No. 111). See further plates I, II, \& IV. 
PALAEONTOLOGIA SINICA

Grabau: Ordovician Fossils of N. China

P1.V.

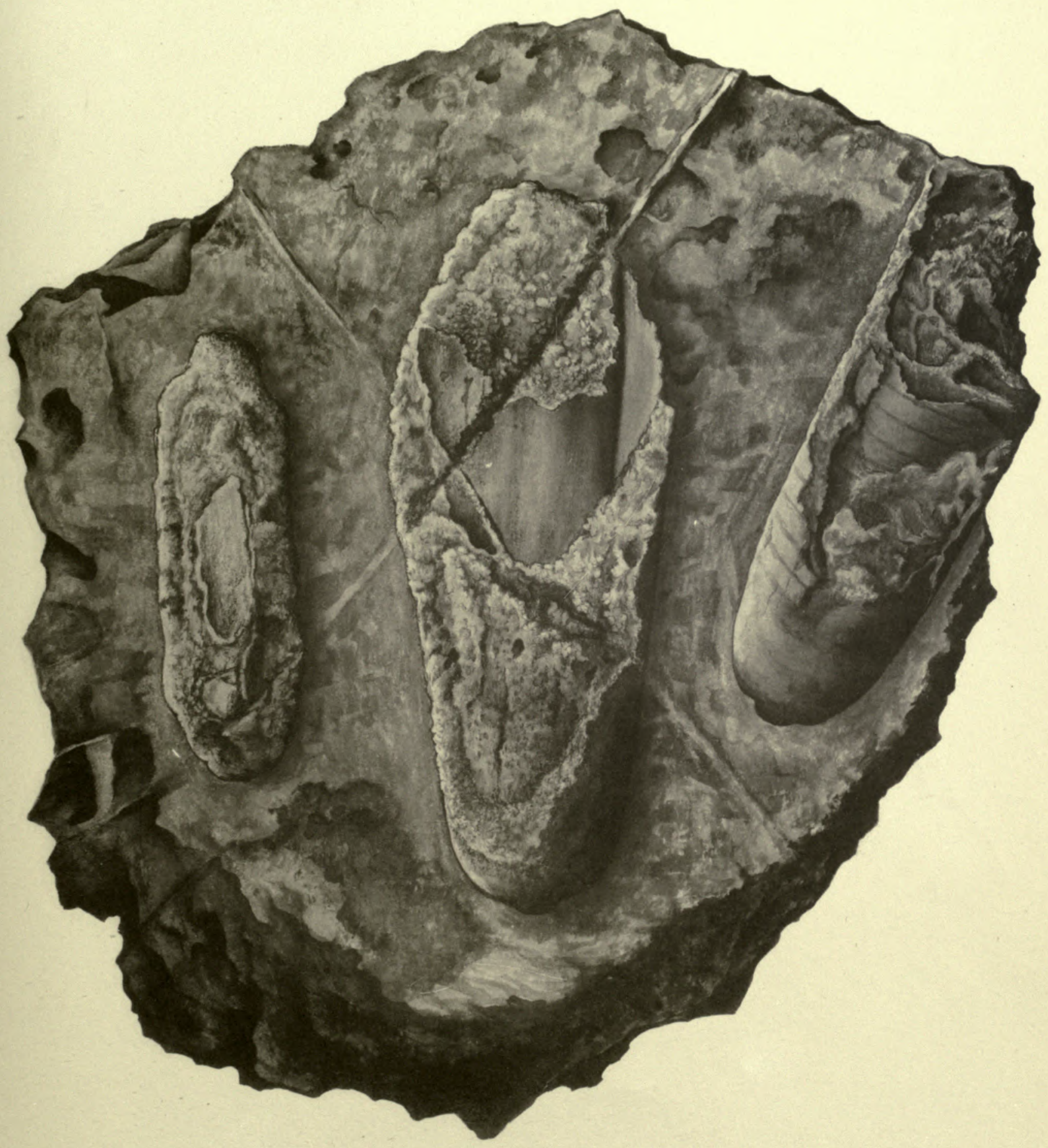





\title{
EXPLANATION OF
}

\author{
PLATE VI
}

(I) 117 


\section{PLATE VI.}

\section{Upper Ordovician Cephalopoda:-Machiakon Limestone.}

\section{Drawings by $K$. C. Liv (劉光城)}

Fig. 1. Cyeloceras? peitoutzense Grabau.

p. 63

Fragment of the small end of a shell with rounded annulations. Natural size. Machiakou limestone, Pei-Tou-Tze (near Chao-Kou-Chuang), Chihli. (Cotype, G. S. Ch. Cat. No. 2S).

Fig, 2. Cycloceras? peitontzense Grabau

Living chamber (without septa) of an immature iudividual, witls sharp annulations. Natural size. Machiakou limestone, Pei-Tou-Tze (Kaining basin), Chihli. (Cotype, G. S. Ch. Cat. No. 29).

Fig. 3. Cycloceras? peitoutzense Grabau

The largest specimen obtained, partly embedded in rock. In the upper part is shown a portion of what was probably the living chamber. The surface here shows very fine concentive strix (see fig. 4 ). The lower part, which appears to be part of the same specimen does not preserve the strie. The position of the tro fragments, and the form of the smaller one suggest that the sliell was curved. Natural size. Mackiakon limestone, Clao-Kou-Chuang, Chihli. (Cotype, G. S. Ch. Cat. No. 107).

Fig. 4. Cycloceras? peitoutzense Grabau.

Eulargement of part of surface of figure. $3,(\times 3$.$) to show the fine concentric$ strice.

Fig. 5. Stereoplasmoceras pseudoscptatum Grabau..................................... 66

5a. Longitudinal section of a large specimen, not showing siplunncle, but showing pseudosepta and stereoplasmic filling. Natural size.

5b. Cross section of the same. Natural size. Machiakou limestone, Tangshan, Chibli. (Cotype, G. S. Ch. Cat. No. 58).

Fig. 6. Stereoplasmoceras pseudoscptetum Grabau....................................... 60

6a. Longitudinal section, showing depth of septa, pseudosepta, and filling of stereoplasm. Natural size.

(ib. Cross-section of same. Natural size. Macliakou limestone, Ning-Yang, Shantung. (Cotype, G. S. Ch. Cat. No. 57).

Fig. 7. Stereoplasmoreras pseudoseptatum Grabau........................................ 66 A natural section, weathered, showing the septa, pseudosepta and excentric siphuncle. The strongly nummuloidal character is shown in the lower part and the non-Actinoceran type of filling in the upper. Natural size. Machiakou limestone, Chao-Kou-Chuang, Chihli. (Cotype, Survey Expedition Coll., G. S. Ch. Cat. No. 78).

Fig. 8. Stereoplasmoceras machialionncnse Grabau

A natural section in the rock, showing narrowly nummuloidel siphuncle, psendosepta and filling of stereoplasm. Naturn] size. Machiakou limestone, Ma-Chia-Kou, Chilıli. (Holotype, H. C. T'an Coll., G. S. Ch. Cat. No. 15). 
PALEONTOLOGIA SINICA

Grabau: Ordovician Fossils of N. China

P1.VI.
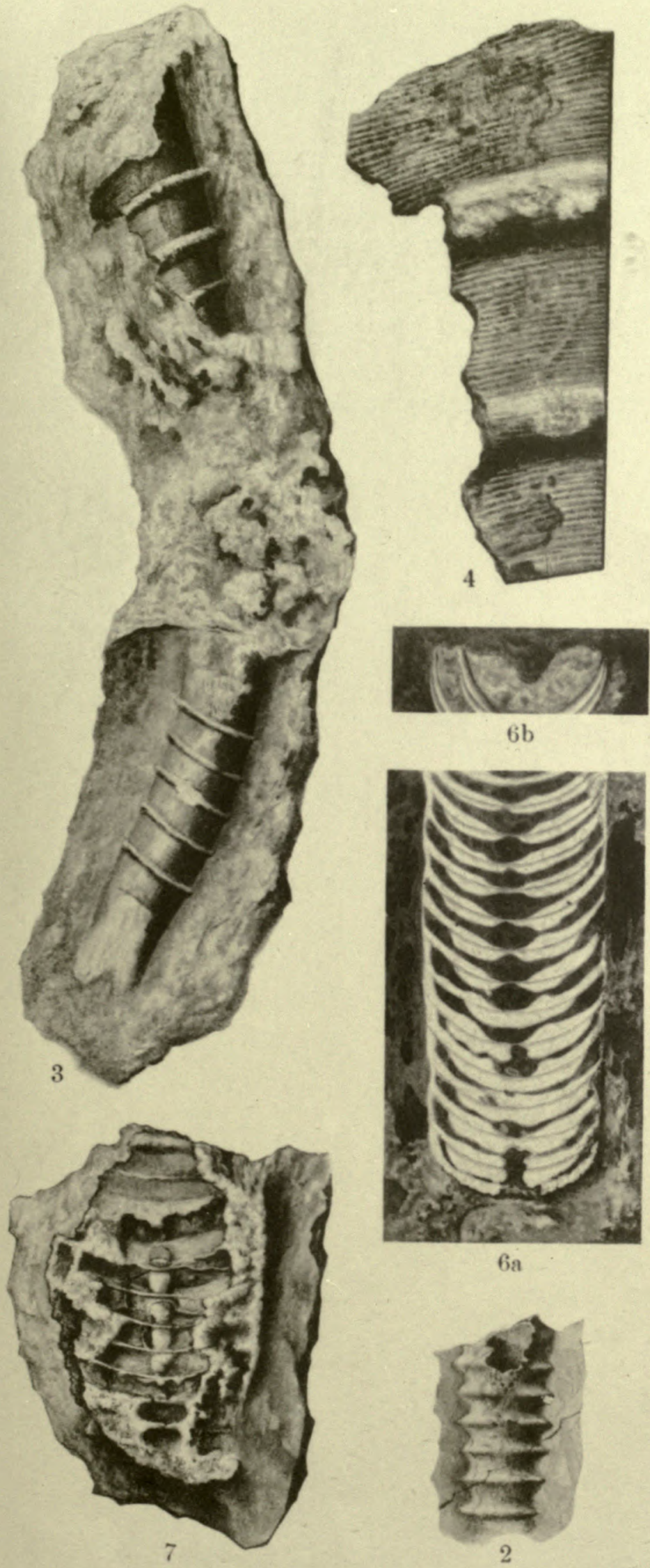

$6 \mathrm{~b}$
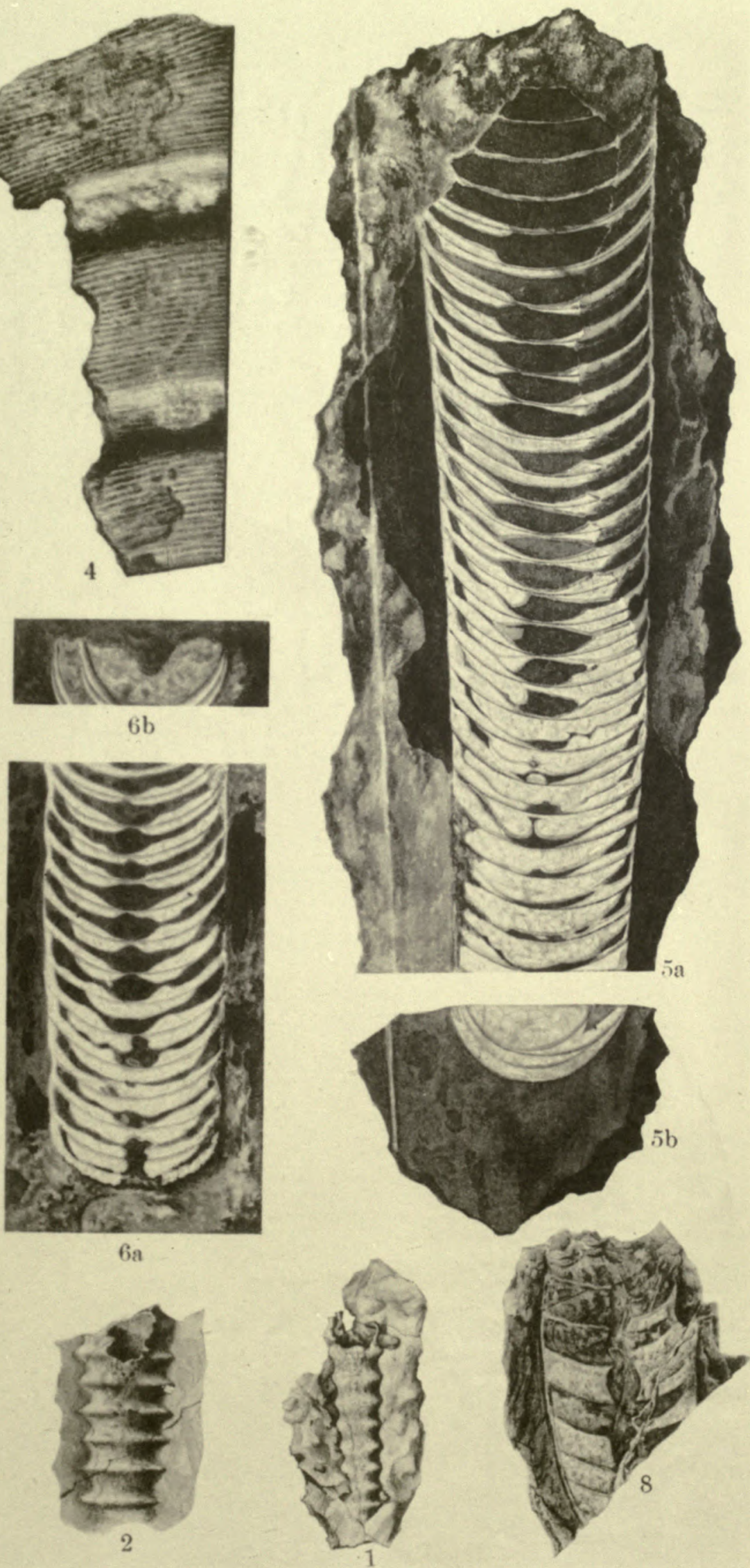



\section{EXPLANATION OF}

PLATE VII

(I) 119 
Upper Ordovician Cephalopods:-Machiakon Limestonc.

\section{Drawings by K.C. Liu (硂光城)}

Fig. 1. Actinoceras richthofeni Frech.................................................... 75

An average adult individual weathered so as to show siphuncle. The specimen probably represents a little more than half the original length. Natural size. Machiakou limestone, Tangshan, Chilıli. (T. C. Wang Coll. G. S. ('h. Cat. No. 5).

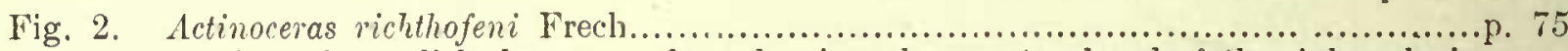
Portion of a polished rock surface showing the apertural end of the siphuncle in section. The gradual thickening of the septal rosettes is shown. Also a portion of the camerate part of the shell is shown. Natural size. Machiakou limestone, Huo-Lul, Chilhli. (Coll. Miss Clarke; G. S. Ch. Cat. No. 13).

Fig. 3. Actinoccras richthofcni Frech.........................................................
A portion of a weathered section of the siphuncle, showing the rosettes around the septal necks and the nature of the endosipliuncle and its diverticula. Enlarged three times. Machiakou limestone. Tangshan, Chilıli. (T. C. Wang coll., C. S. Cl. Cat. No. 5). (See also plate IX).

Fig. 4. Actinoceras .tani Grabau.....

4a. Longitudinal section showing open endosiplunncle. Natural size.

4b. Transverse section. Natural size. Nachiakou limestone, Kushan, Huo-Luh-Hsien, Chihli. (Cotype, G. S. Cl. Cat. No. 69).

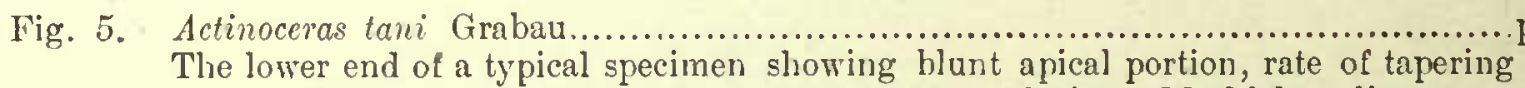
and; in upper part, septa and siphuncle. Natural size. Machiakou limestone, Tangshan, Chilıli. (Cotype, Coll. Messrs. Morris, Terrill \&E Barbour, G. S. Ch. Cat. No. 26).

Fig. 6. Actinoceras tani Grabau........................................................ 80 Natural weathered section, showing siphuncle with part of endosiphuncle exposed, and the nature and amount of the stereoplasm in the camers. Machiakon limestone, Ma-Chia-Kou, Chillli. (Cotype, H. O. T'an coll. G. S. Cl. Cat. No. 1).

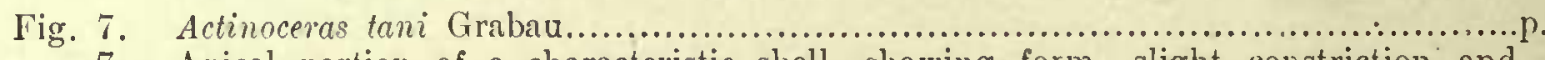

7a. Apical portion of a characteristic shell, showing form, slight constriction and sutures. Also the large subconical initial cliamber. Natural size.

7b. A pical view of the same showing the scar of the siphuncle with its swollen rim, situated subcentrally at this end; at the upper end of the fragment the sipluncle is strongly excentric. Natural size.

7c. A single nummulus of the siphuncle, with surrounding septal portion enlarged $X$ 4 , to show the mural pores on the periphery. Machiakou limestone, Tangshan. (Cotype, Coll. Messrs. Morris, Terrill and Barbour, G. S. Cl. Cat. No. 16). (See further, plate IX).

Fig. 8. Actinoceres nanum Grabau....

Natural section of the a pical portion of a typical specimen, showing the small siphuncle with its endosiphuncle, the septa, and rate of tapering. Natural size. Machiakou limestone, Tangshan, Chilhli. (Iolotype, T. C. Wang Coll. (i. S. Ch. Cat. No. S). (See also plate IX). 


\section{PALEONTOLOGIA SINICA}
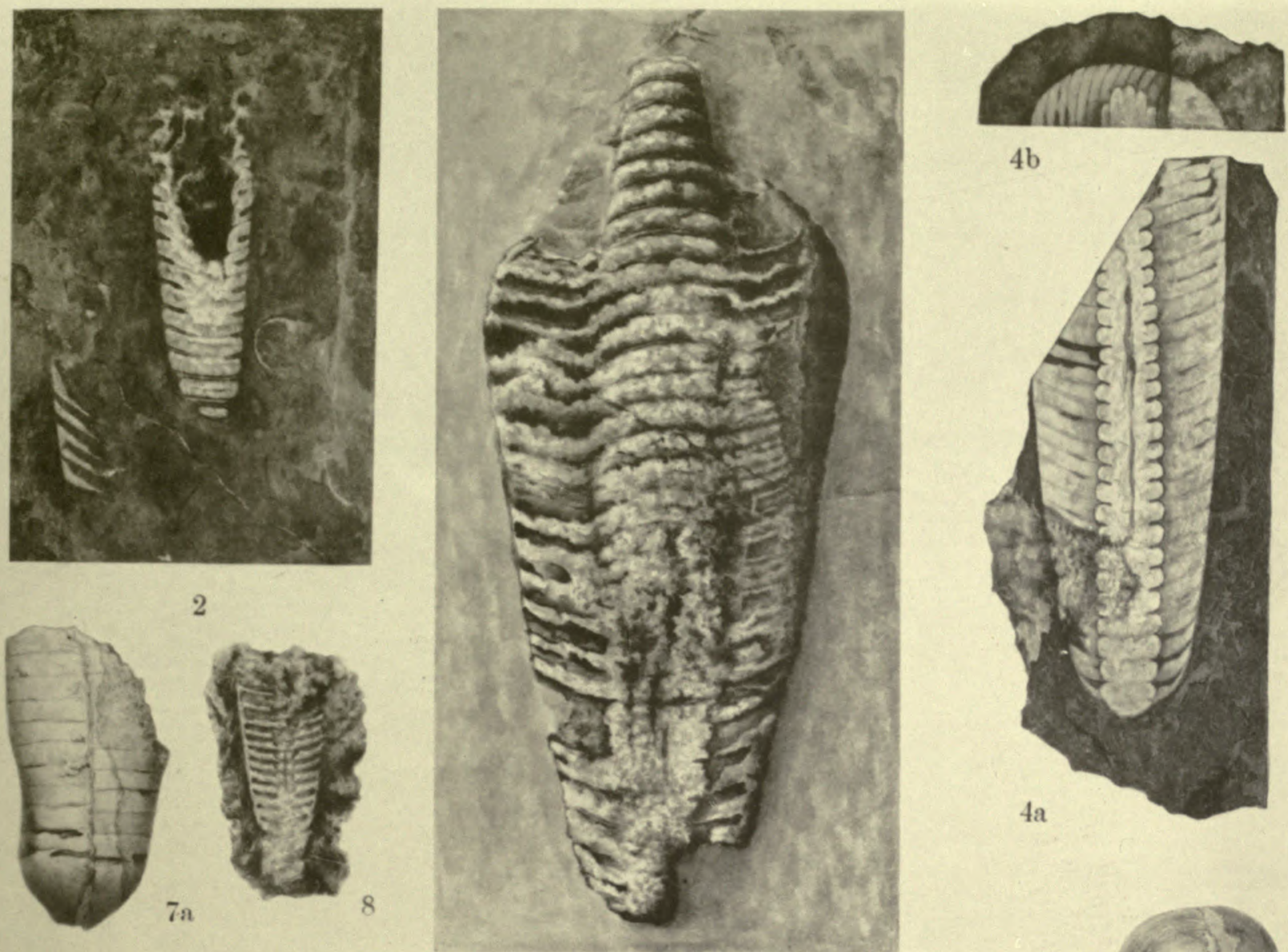

\section{1}
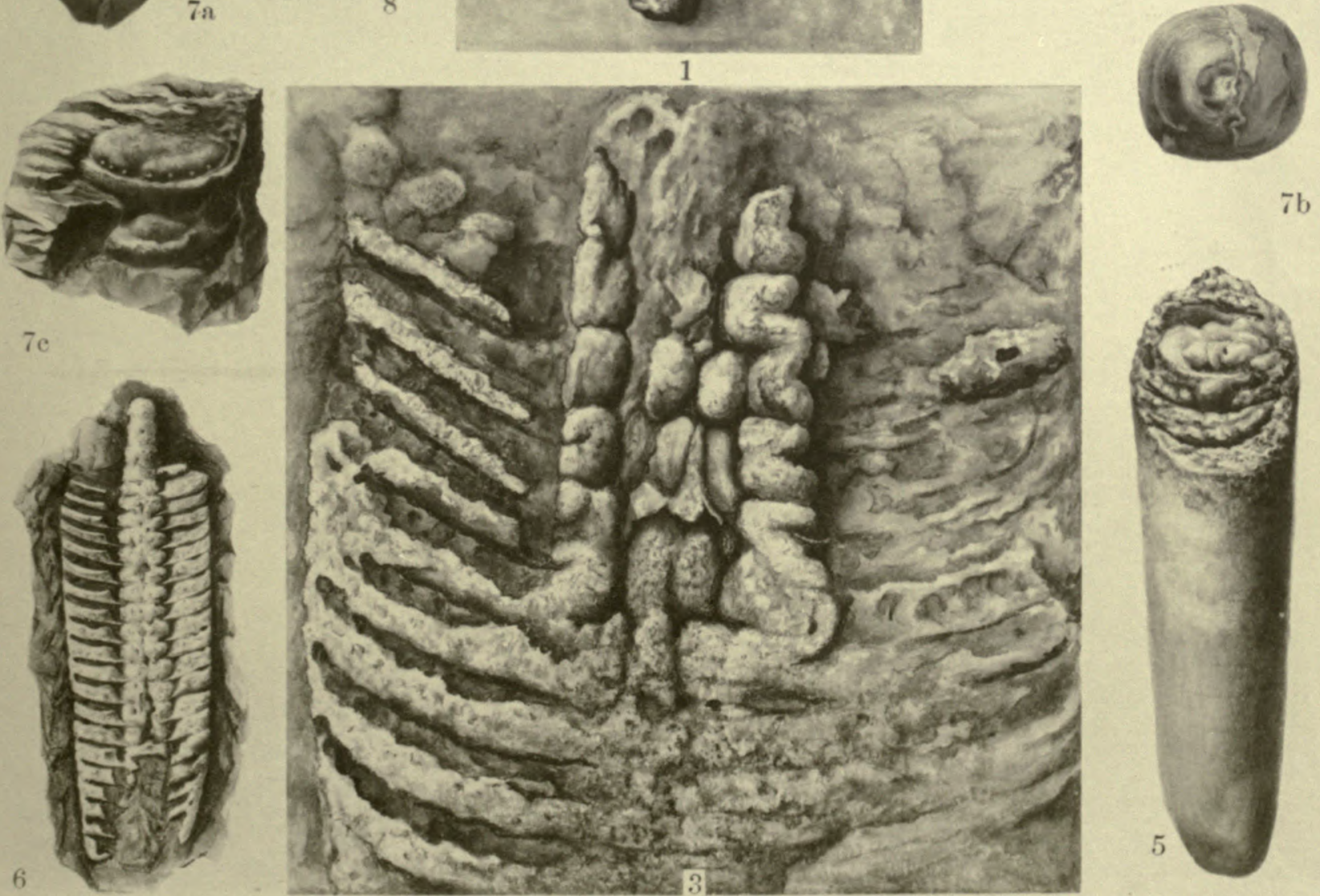



\title{
EXPLANATION OF
}

\author{
PLATE VIII
}

(I) 121 


\section{PIATE VIII.}

Upper Ordovician Cephalopoda:- Machiakou Limestone.

\section{Drawings by K. C. Liu (劉光城)}

Fig. 1. Actinoceras coulingi Grabau.....................................................p. 82

A natural section upon the rock surface, somewhat weathered, and showing the siphuncle, irregular septa, and filling of camerx by stereoplasm. Natural size. Machiakou limestone, Hsi-Hsien, Honan. (Cotype, A. C. 'T'aun coll., G. S. Ch. Cat. No. 4).

Fig. 2. Actinoceras coutingi Grabau.

Polished section of a characteristic specimen, slowing the siphuncle and nature and extent of filling of camere. Natural size. Machiakou limestone, Ma-Chia-Kou, Chihli. (Cotype, H. C. T'an coll. G. S. Ch. Cat. No. 27).

Fig. 3. Actinoceras suanpanoides Grabau... p. 84

3a. Somewhat oblique polished section showing depth of cameræe and their filling, and, in the lower part, the siphuncle. The rate of tapering appears abnormally great owing to the oblique direction of the section. Natural size.

3b. Transverse section of upper end. Machiakou limestone, Tui-An, Shantung. (Cotype, G. S. Ch. Cat. No. 53).

Fig. 4. Actinoceras suampanoides Grabau.............................................. 84

4a. Polished section, showing the characteristic sipluuncle, rate of tapering of shell, and filling of camerse.

4b. Transverse section of same showing excentric position of siphuncle. Machiakou limestone, Shantung. (Cotype, G. S. Ch. Cat. No. 54). (See further plate IX).

Fig. 5. Actinoceras submarginale Grabau................................................. p. 86

5a. Polished section through the siphuncle showing distant septa with cameræ largely filled by stereoplasm. Also part of the endosiphuncle. Natural size.

5b. Transverse section of a part laterally displaced by a small fault, showing size and submarginal position of sipluncle. Naturâl size. Machiakou limestone, T'angshan, Chilıli. (Cotype, G. S. Ch. Cat. No. 55). (Sec also plate IX).

Fig. 6. Actinoceras curvatum Grabau................................................... 88

A weathered specimen on rock showing curved form, septr with partial filling of camerre, and siphuncle. Natural size. Machiakou limestone, Lincheng, Shantung. (Holotyge, F. F. Mathieu coll., G. S. Ch. Cat. No. 77)

Fig. 7. Cyrtactinoceras frechi Grabau...

A weathered fragment near the apical end, showing sipluuncle and septa, the camerre scarcely obstructed by stereoplasm. The slight curvature scarcely appears in this view. Natural size. Machiakou limestone, Tungshan. Chilhli. (Cotype, T. C. Wang coll. G. S. Ch. Cat. No. 2).

Fig. 8. Cyrtactinoceras frechi Grabau............................................. p. 89

A small fragment near the apical end, showing sutures. Enlarged $\times 2$. Macliakou limestone. Chao-Kou-Chuang, Chilıli. (Cotype, G. S. Ch. Cat. No. S8).

Fig. 9. Cyrtactinoccras frechi Grabau.

9a. An apical portion somewhat weathered. Natural size.

9b. Section of same, showing excentric siphuncle. Natural size. Macliakou limestone, Sliantung. (Cotype, G. S. Cl. Cat. No. 66). 


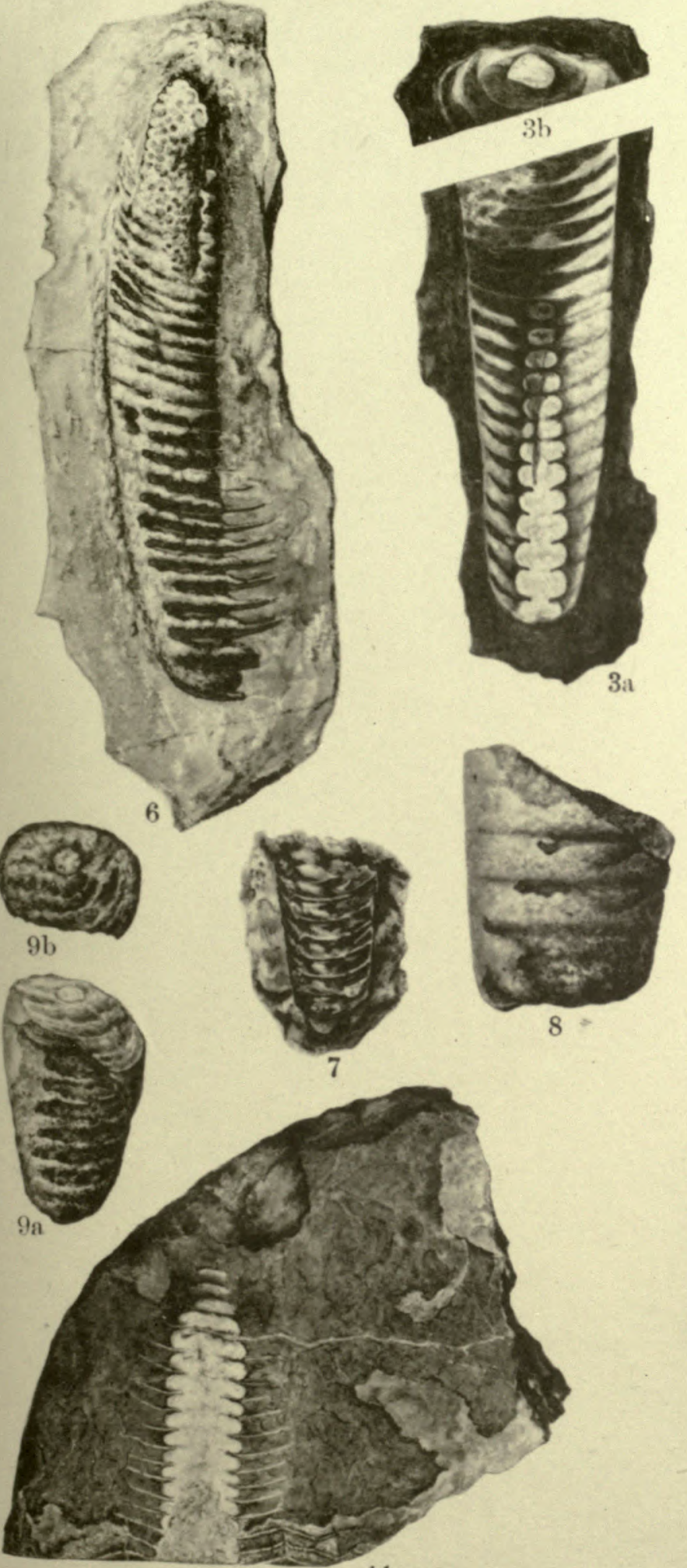

11 a

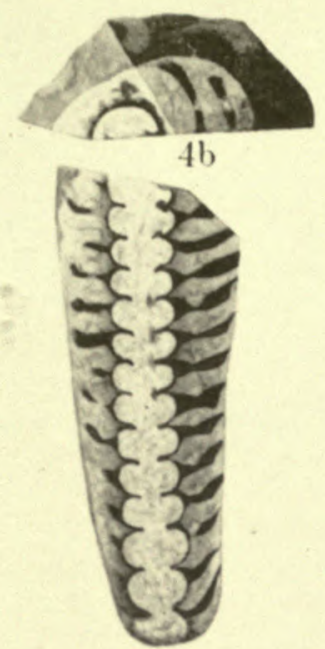

$4 a$
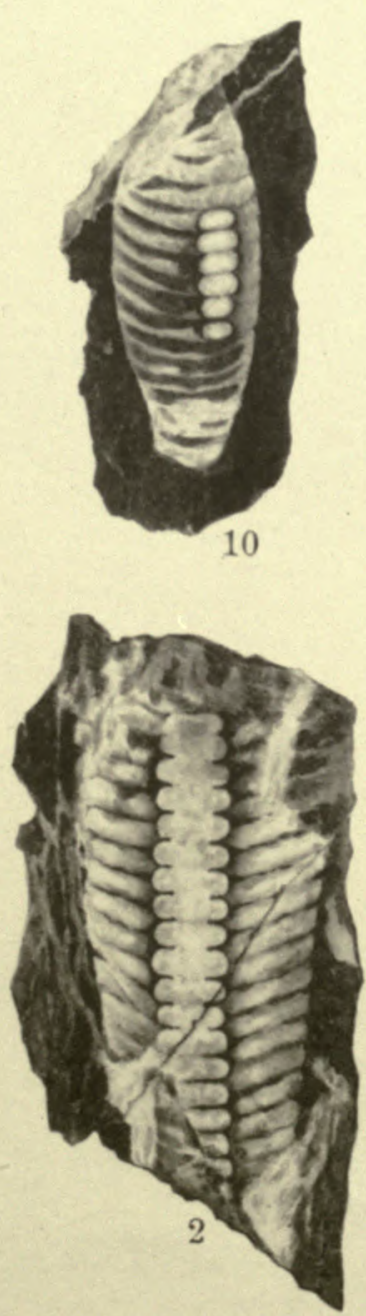
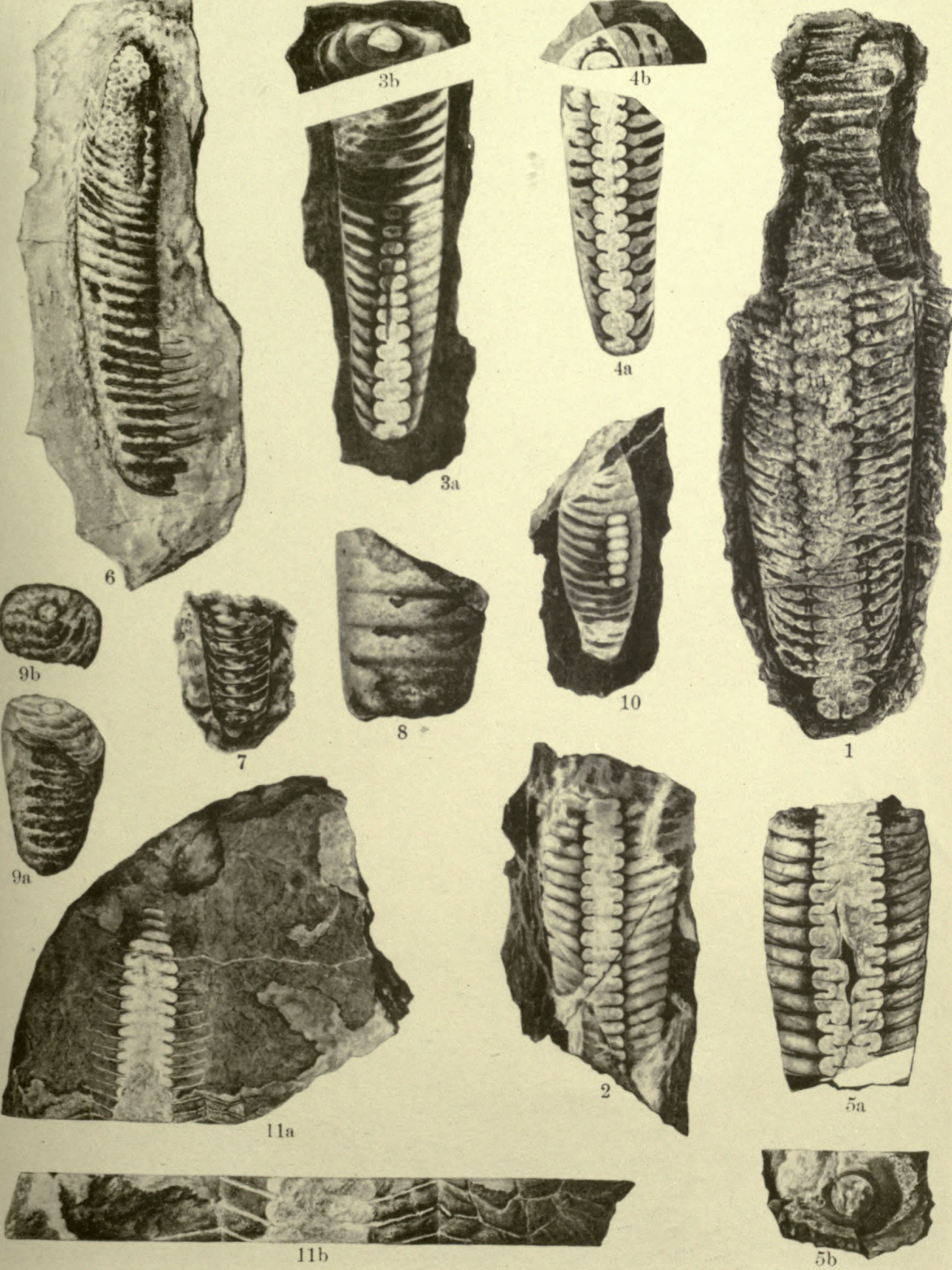

Fig. 10. Cyrtactinoceras frechi Grabau.

p. 89 A polished section showing part of the curved siphuncle. Natural size. Machiakou limestone, Ching-Chuang, Ning-Yang, Shantung. (Cotype, V. K. Ting coll. G. S. Ch. Cat. No. 72).

Fig. 11. Gonioceras shantungense Grabau ....

11a. Polished section of the holotype and only known specimen. Natural size. The section shows the siphuncle, empty cameræ and incomplete septa. In the lower - right hand portion the lateral continuation of the septa is shown. Machiakou limestone, Seng-Chuang, Ning-Yang, Shantung. (Holotype, V. K. Ting coll., G. S. Ch. Cat. No. 10).

11b. The lower part of the same specimen enlarged twice to show more fully the geniculated portion ot the septa. 



\title{
EXPLANATION OF
}

\author{
PLATE IX
}




\section{PLATE IX. \\ Cephalopods from the Early Upper Ordovician:-Machiakou Limestonc.}

Drawings by K.C. Liu (劉光城)

Fig. 1. Actinoccras suanpanoides Grabau. p. 84

1a. Lateral view of a characteristic specimen, showing rate of tapering and distance of septa. Natural size.

1b. End viow of same. The right side is slightly crushed. Natural size. Machiakou limestone, Wên-Nan, Mon-Yin-Hsien Shantnng, V. K. Ting coll. (Cotype, G. S. Ch. Cat. No. 111).

Fig. 2. Actinoceras nanum Grabau p. 87

A natural section, showing the very slight amount of stereoplasm. Natural size. Machiakou limestone, Tangshan, Chihli. (Paratype, Surrey Expedition coll. G. S. Ch. Cat. No. 73).

Ftg. 3. Actinoceras submaryinale Grabau. p. 86

A weathered fragment showing the large submarginal siphuncle, and the septa and nearly empty camers. A small part of the shell is preserved in the upper left hand area. Natural size. Machiakou limestone, Tangshan, Chihli. (Cotype, G. S. Ch. Cat. No. 56).

Fig. 4. Actinoceras richthofcui Frech

A natural weathered section, showing the forward deflection of the lateral diverticula of the endosiphuncle. Natural size. (See text figure 19 p. 79). Macliakou limestone, Lincheng, Shantung, (F. F. Mathieu coll., G. S. Ch. Cat. No. 67).

Fig. 5. Actinoceras richthofeni Frech

Section of a part of a shell in which the filling of the cameræ has been unusually extensive. Natural size. Machiakou limestone, Huo-Luh-Hsien, Chibli. (G. S. Ch. Cat. No. 64).

Fig. 6. Actinoceras richthofeni Frech.

Section showing part of endosiphuncle, and the moderate amount of filling characteristic of the cameræ. Natural size. Machiakou limestone, Chilhli (?). (Coll. V. K. Ting, G. S. Ch. Cat. No. 52).

Fig. 7. Actinoceras richthofeni Frech.

7a. Lateral view of a characteristic internal septate mold, showing rate of lateral tapering and flexuous character of suture. Natural size.

$7 \mathrm{~b}$. Side view of the same specimen showing the compressed form. On the worn part the deep concavity of the septa is indicated. Natural size.

7c. View of the polished upper end of the same specimen, showing the oral form of the shell and the corresponding oval form and centran position of the siplunncle. Natural size.

7d. Median longitudinal section of the same specimen, showing the deep concavity of the septa, the character of the nummuli with the median endosiphuncle, and the lateral diverticula opening in pores on the outer surface of the nummuli. Natural size.

7e. Surface of the opposite half of the same specimen, separated from $7 \mathrm{~d}$ by about $1 \mathrm{~mm}$. Machiakou limestone, Wên-Nan, Mon-Yin-Hsien Shantung. V. K. Ting coll. (Geol. Survey Ch. Cat. No. 107).

Fig. 8. Actinoccras richthofeni Frech p. 75 End view of a fragment of an earlier nart of the shell than that shown in fig. 7 . 
PALEONTOLOGIA SINICA

Grabau: Ordovician Fossils of N. China

P1.IX.
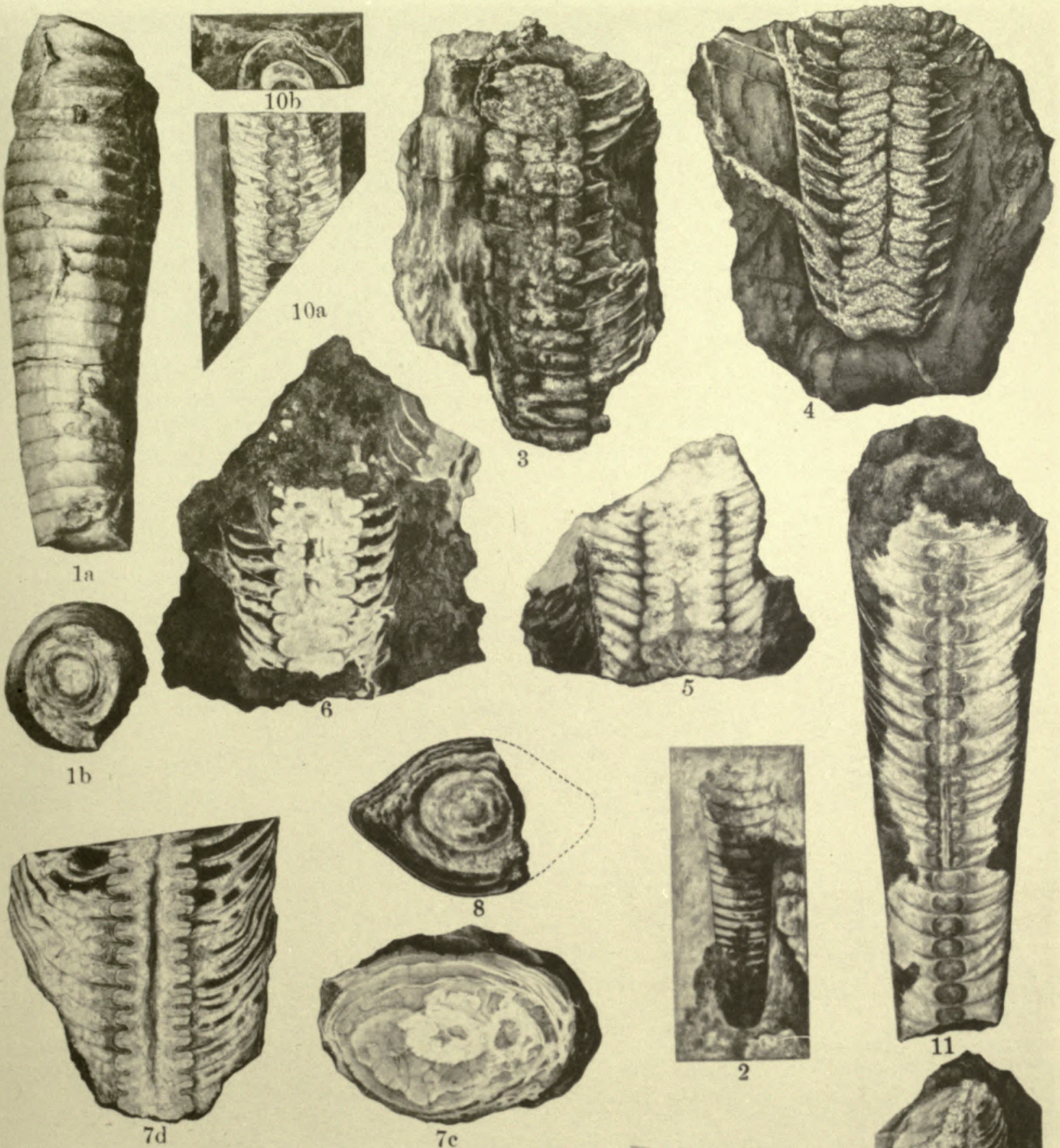

with part of outline restored. This shell shows a more acute lateral angle (slightly emphasized by compression, and a more nearly circular and proportionately large siphuncle. Machiakou limestone, Wên-Nan, Mon-Yin-Hsien, Shantung. V. K. Ting coll. (G. S. Ch. Cat. No. 108).

Fig. 9. Stereoplasmoceras actinoceriforme Grabau

9 a. Section through siphuncle, showiug the filling of crystalline limestoue, but without regular arrangement as in Actinoceras. Natural size.

9b. Lower end of the same specimen. Natural size. Machiakou limestone, Wên-Nan, Mon-Yin-Hsien, Shantung. (Cotype, V. K. Ting coll., G. S. Ch. Cat. No. 112).

Fig. 10. Stereoplasmoceras actinnceriforme Grabau........................................... 69

10a. Longitudinal section of a specimen showing hollow nummuli of siphuncle below and filling with matrix in upper part. Also irregular pseudosepta and filling of stereoplasm. Natural size.

10b. Cross-section of the same. Natural size. Machiakou limestone, Kushan, Chihli. (Cotype, V. K. Ting coll. G. S. Ch, Cat. No. 60).

Fig. 11. Stereoplasmoceras pseudoseptatum Grabau. p. 66 Longitudinal section of an early portion of a conch, showing character of septa, eameræ and siphuncle. Natural size. Machiakou limestone, Scuth of Wên-Nan, Mon-Yin-Hsien, Shantung. V. K. Ting coll. (Cotype, G. S. Ch. Cat. No. 112). 

中
國
古
生
物
誌

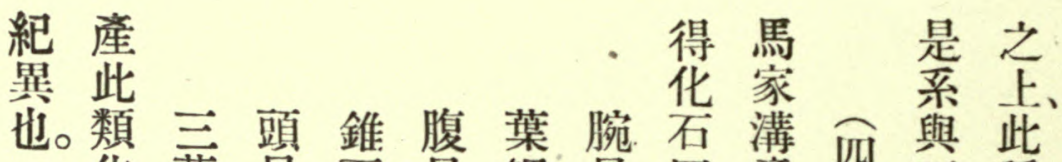

华葉足石足鰓足四產四市種

石虫類 類 類 類 類十珠 馬 奥 石

岩

公角家陶灰

膚、

種、石 溝 紀 岩

興

已石岩產

北

美

这

20

㤩六六杂六六

種種種種種 種

經灰 畨 吸

經 岩及若

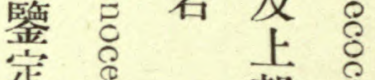

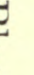

定者

僅馬

章

有甚

家化

溝 石

三賉石兩

四名灰種、

種岩其

之時

茲珠 關 代

分角係、似

列石倘屬

愿

之石 難 中

如灰 確 奥

上

左。岩。定。陶

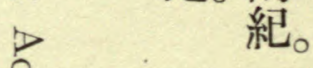

$\equiv$

陶

紀

下

部

巳.

อุด

相

掌、

當、

然

究

與

中

國

南

部

奥

陶

此

石

灰

岩

中、

共 


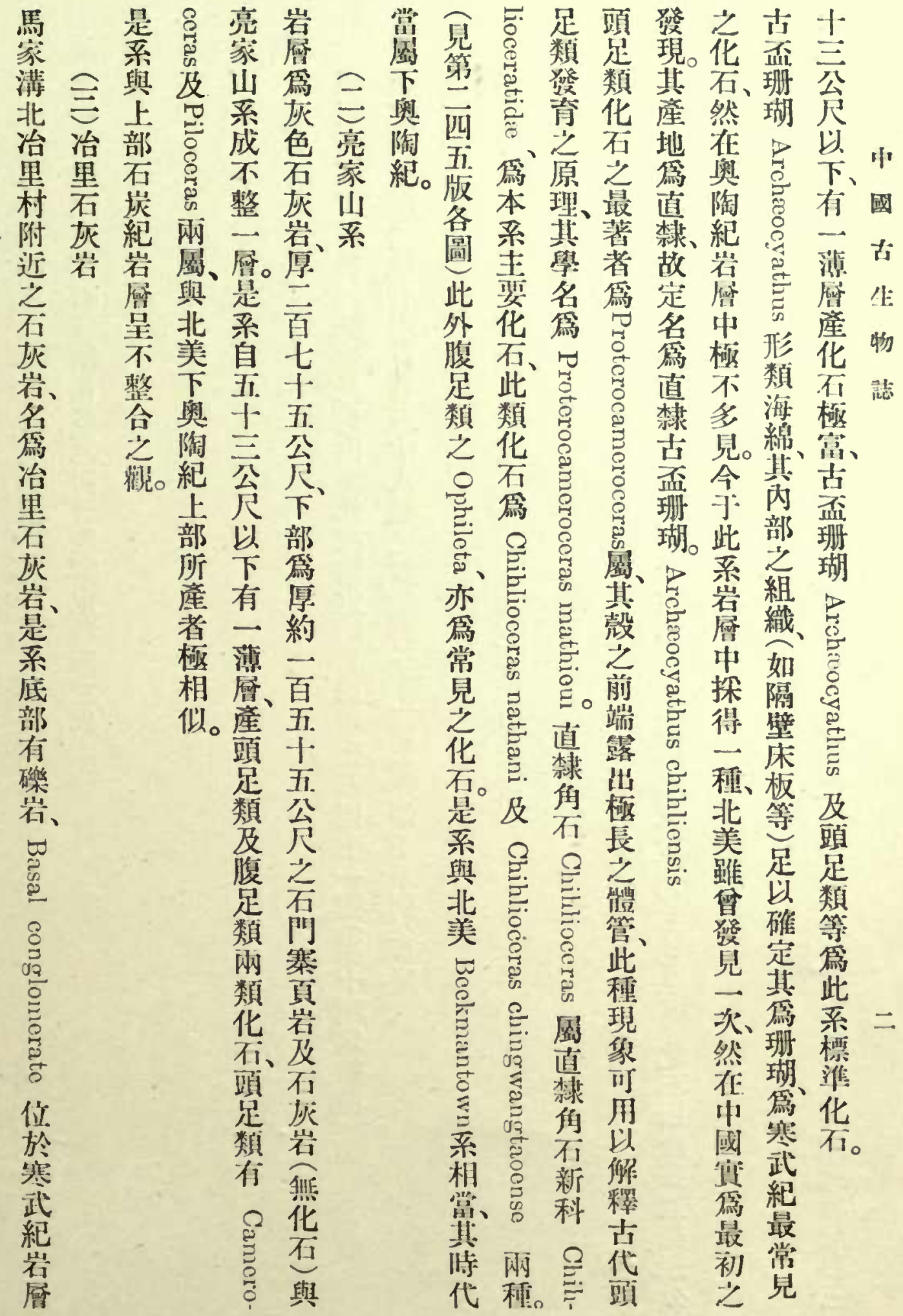




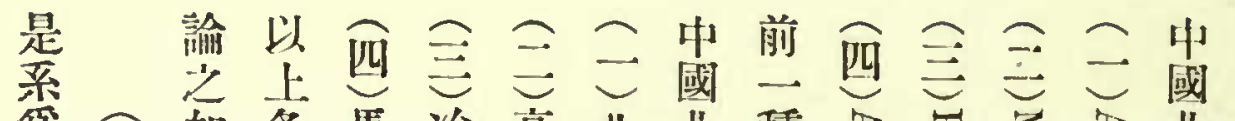

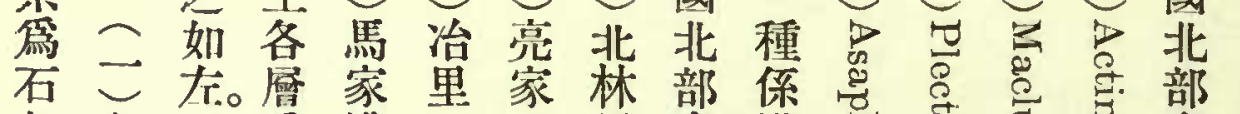

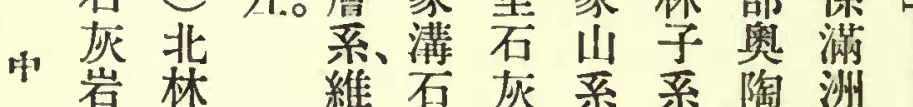

國所留理㶪岩采系陶洲

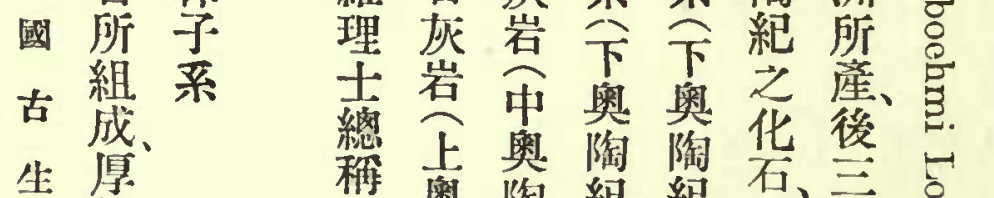

物 約

誌

南

公

分

佈

於

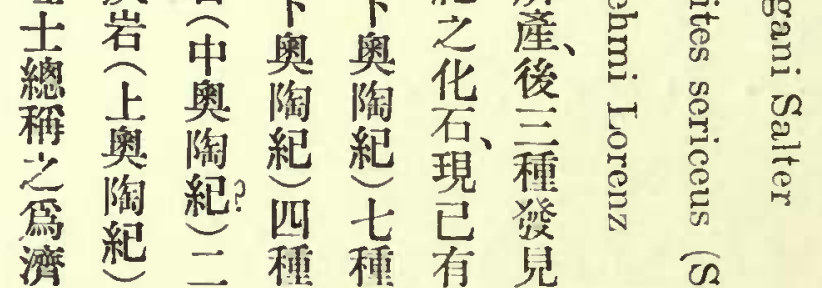

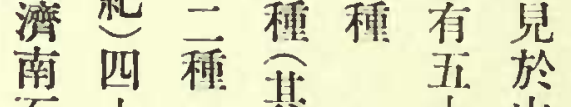

石一

灰宍

岩、種

李

直

隸

東

北

䧗

榆

縣

不

鬥

寨

希

-

帶、

其

時

一 代

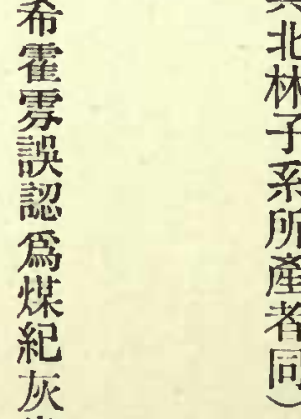

帒公東。递

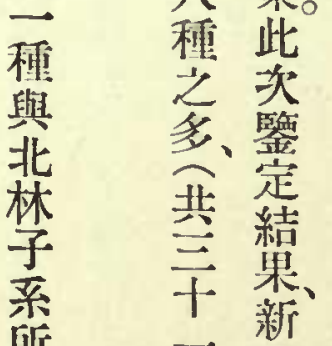

所哲增

者 华

同分不

岩。

集嵒

每

下 䄸

紊西

系。十

種

华

下

奚

新

奥因秏

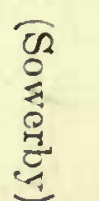

奥因秏

孫葛

零利

简

紀。

系

岩

曆

互

踏然

譯原

述诺

息 
中

中

華

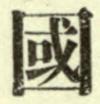

1

民

北

國

十

밋

年

四

月

奥

生

物

第 表志

- Z

册 種

篇

降

啹

農

商

和

部

地

動

質

調

物

暮

查

所

印

化

利

行

堭

著

石 

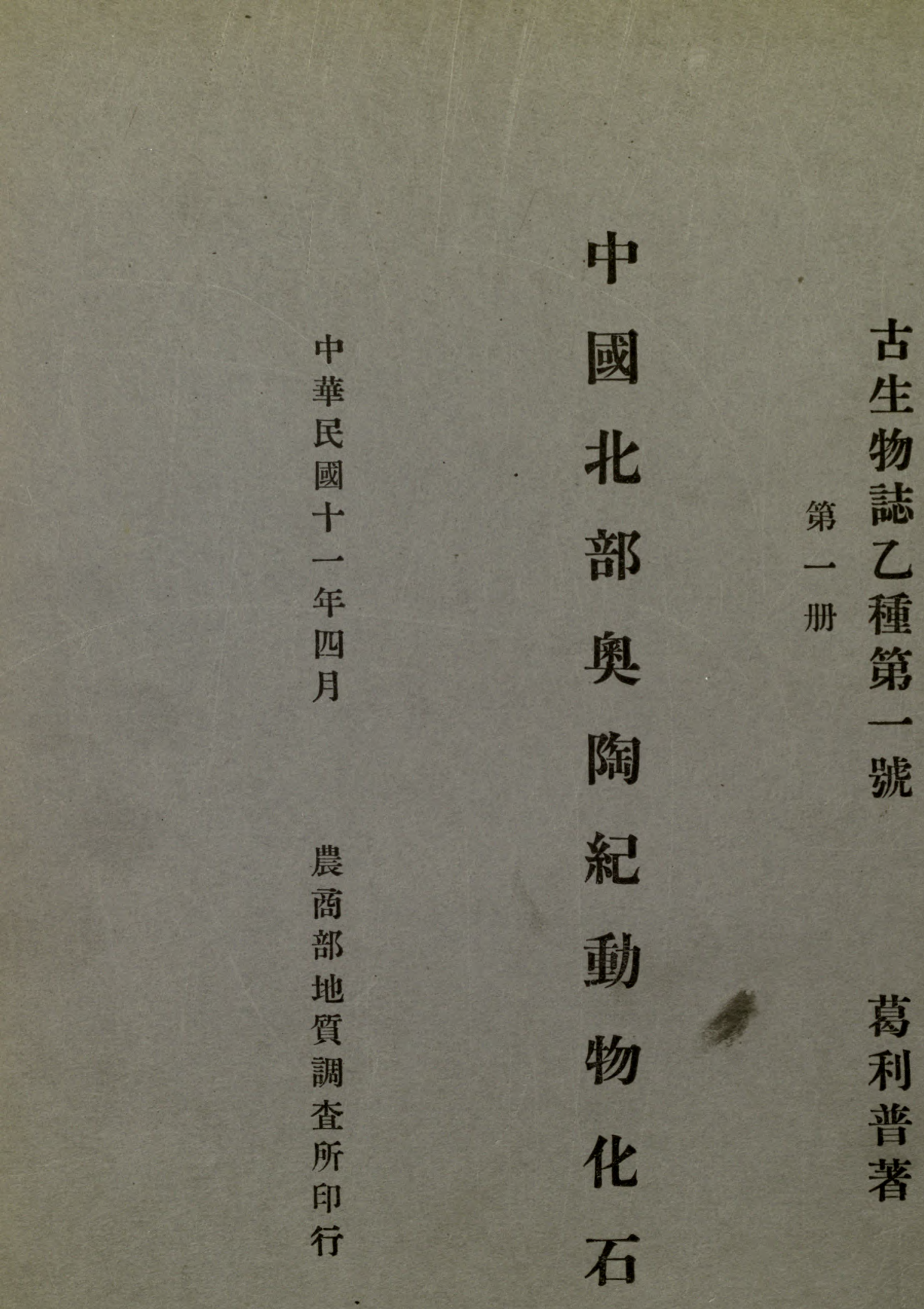

中

民

國

第 誌

- 乙

册 種

第

號

農

䊁

话

動

地

暮

調

利

査

所

的

普

著

石 



\section{DAY USE}

\section{RETURN TO DESK FROM WHICH BORROWED}

EARTTH SCIENCES LIBRARY

This book is due on the last date stamped below, or on the date to which renewed.

Renewed books are subject to immediate recall.

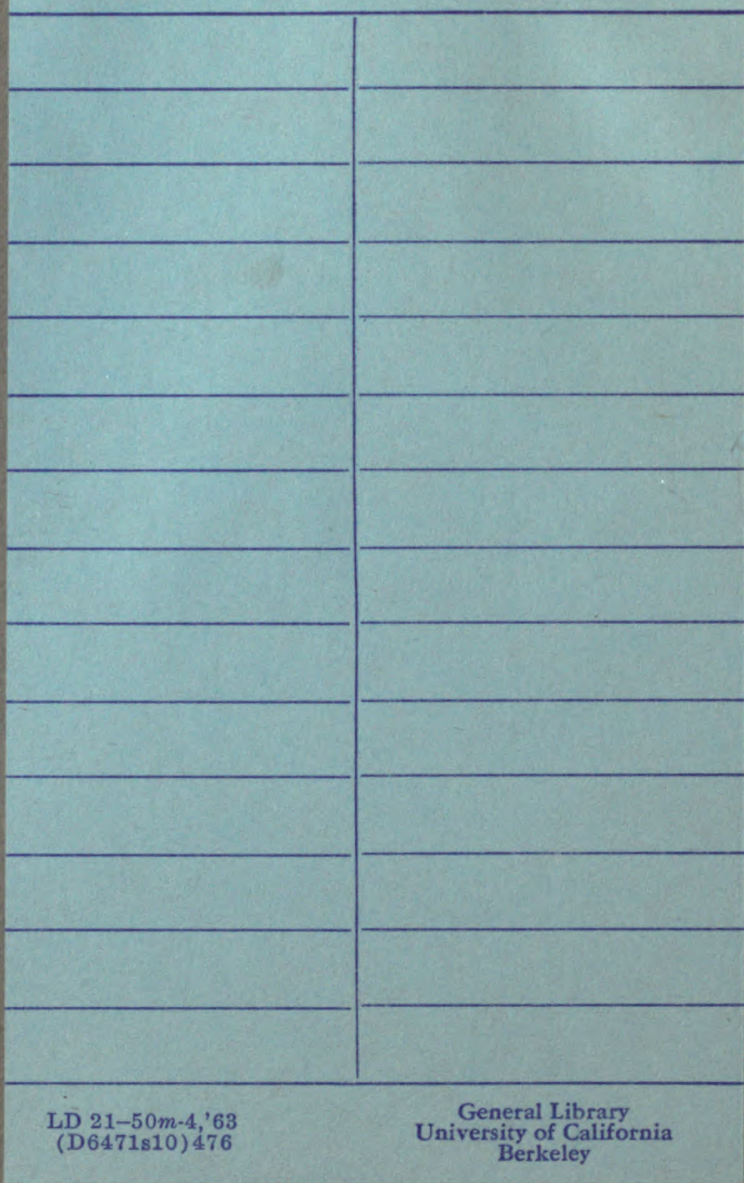




\section{N.254235}

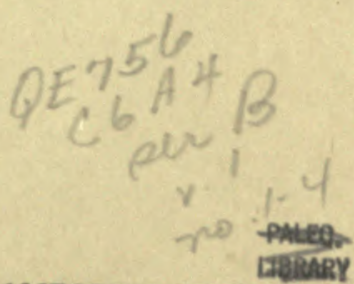

THE UNIVERSITY OF CALIFORNIA LIBRARY 
